\title{
Ultrasensitive Bioanalytical Assays for Cytotoxic Drugs: Focus on Locally Administered Anti-Cancer Agents
}

\author{
Liia D. Vainchtein ${ }^{*}, 1$, Hilde Rosing ${ }^{1}$, Jan H.M. Schellens ${ }^{2,3}$ and Jos H. Beijnen ${ }^{1,2,3}$ \\ ${ }^{I}$ Department of Pharmacy \& Pharmacology, Slotervaart Hospital/The Netherlands Cancer Institute, Louwesweg 6, 1066 \\ EC Amsterdam, The Netherlands \\ ${ }^{2}$ Division of Drug Toxicology, Department of Pharmaceutical Sciences, Beta Faculty, Utrecht University, P.O. Box \\ 80082, 3508 TB Utrecht, The Netherlands \\ ${ }^{3}$ Department of Medical Oncology, Antoni van Leeuwenhoek Hospital, The Netherlands Cancer Institute, Plesmanlaan \\ 121, 1066 CX Amsterdam, The Netherlands
}

\begin{abstract}
Local administration routes have been investigated to reduce the systemic toxicity and to increase the local efficacy of cytotoxic drugs. Some examples of local administration strategies are cutaneous, intraperitoneal, intrathecal and intravesical chemotherapy. When administered locally, high local drug concentrations can be achieved with increased local efficacy and, conditionally that only small amounts of drug are absorbed into the bloodstream, low systemic toxicity.

Our main purpose is to make an inventory and to comment on the availability of ultrasensitive bioanalytical assays that could determine traces of the drugs that may have passed into the bloodstream, e.g. after local application, and which may lead to the systemic toxicity. We conclude that in the last years, multiple ultrasensitive assays have been designed capable to quantitatively determine very low levels of cytotoxic agents e.g. systemically reached after local administration. Most methods are based on the hyphenated liquid chromatography with tandem mass spectrometric detection.
\end{abstract}

\section{INTRODUCTION}

In this selected overview, we focus on the ultrasensitive assays developed to determine the leakage of locally administered anti-cancer agents into the systemic circulation (Fig. 1).
Intravenous and oral chemotherapy are the most important cancer treatments, however, they can be associated with considerable side-effects. In the past years, local administration routes have been investigated to reduce the systemic toxicity and to increase the local efficacy. Some examples are cutaneous, intraperitoneal, intrathecal and intravesical

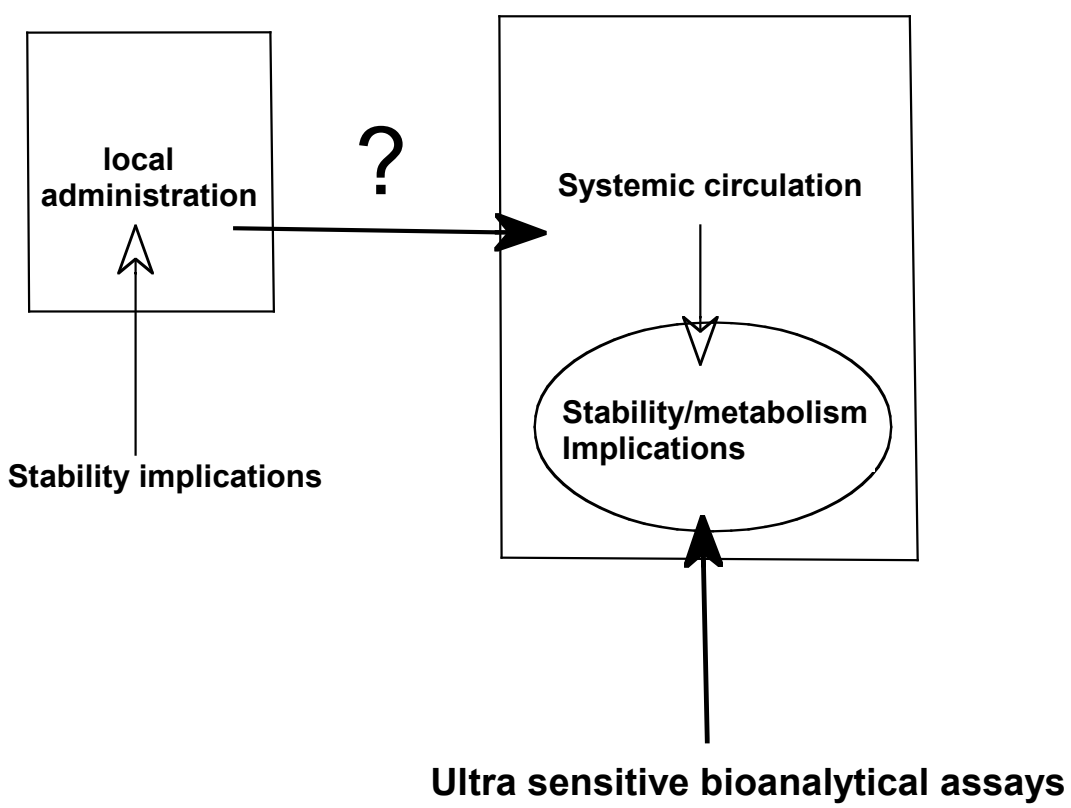

Fig. (1). Model for systemic exposure of locally administered agents.

*Address correspondence to this author at the Department of Pharmacy \& Pharmacology, Slotervaart Hospital, Louwesweg 6, 1066 EC Amsterdam, The Netherlands; Tel: +31 (0)20 512 4073; Fax: +31 (0)20 512 4753; Email: liia.vainchtein@slz.nl chemotherapy. Important advantages of these administration routes are high local drug concentrations with local efficacy and, conditionally that only small amounts of drug are absorbed into the systemic circulation, low systemic toxicity. 
Obviously, it is pivotal to investigate whether the locally administered cytotoxic drug will pass into the bloodstream in sufficient high concentrations that could lead to systemic toxicity. For this purpose ultrasensitive analytical assays are needed because of the low systemic drug concentrations that are reached after most local administrations.

This article gives a selected overview of ultrasensitive bioanalytical assays of locally administered cytotoxic drugs. For other pharmacologic research questions ultrasensitive assays are also needed e.g. metronomic therapies [1,2], microdosing [3], long-term effects [4], monitoring of hospital personnel potentially exposed to cytotoxic agents [5], and for which this review may be useful.

\section{BIOANALYTICAL METHODS}

To quantify any drug and to follow its absorption, distribution, metabolism, and elimination (ADME) in body fluids, sensitive and specific analytical methods are required. Originally, high performance liquid chromatography (HPLC) or gas chromatography (GC) in combination with ultraviolet (UV), fluorescence, or electrochemical detection have been employed to quantify drugs in biomatrices. However, most anti-cancer agents and their metabolites are non-volatile, thermolabile and small polar molecules and therefore, not susceptible to GC [6]. UV detection suffers from low specificity and sensitivity, especially when small polar molecules are the target. Fluorescence and electrochemical detection are more sensitive and specific than UV detection, but they have a disadvantage to be useful only for analytes with fluorescent or electro-active groups. Selective and ultrasensitive detection in bioanalytical analysis was achieved, when HPLC was successfully coupled to mass spectrometry (MS). This hyphenation allowed the selective and ultrasensitive detection of a broad range of anti-cancer compounds and their metabolites [6]. With the introduction of atmospheric pressure ionization (API), atmospheric pressure chemical ionization (APCI) and electrospray ionization (ESI) in the 1980's these techniques were applied more and more for quantitative drug analysis. Nowadays, the use of the improved LC-MS interfaces such as ionspray (ISP, pneumatically assisted ESI), turbo-ionspray or heated electrospray (TISP or HESI; pneumatically assisted ESI with an additional hot drying gas perpendicular to the spray) and heated nebulizer (HN)-APCI (pneumatically assisted APCI) immensely facilitated the evaporation of the HPLC solvents, leading to better ionization and detection of the analytes of interest. Triple-quadrupole mass spectrometers (TSQ), became the 'working horse' for quantitative analysis in the selected reaction mode (SRM). With the introduction of the orthogonal-acceleration reflection time-of-flight (oa-TOF) instruments, which combine the ability to perform accurate mass determination with excellent full-scan ability and the ion-trap storage-reflection TOF instruments, it became possible to detect and quantify not only the parent drugs, but also to identify their metabolites and degradation products accurately and in low concentrations.

With the introduction of API 5000 and TSQ Quantum Ultra's with enhanced mass resolution capability, Q-TOF instruments and Fourier Transform Ion Cyclotron Resonance Mass Spectrometry (FT-ICR-MS) the determination of very low levels of the compound of interest became possible.
Chromatography is not limited anymore to reversedphase mode, but more and more other approaches such as supercritical fluid chromatography and Hydrophilic Interaction Chromatography (HILIC) ("normal-phase" chromatography) are employed. Moreover, porous graphitic carbon material enables chromatographic separation and analysis of analytes with varying structural differences and polarities in a single analytical run.

Another exciting development was the hyphenation of HPLC and nuclear magnetic resonance (HPLC-NMR) technology, facilitating molecular structures identification of e.g. unknown metabolites [7].

In conclusion, these techniques made it possible to develop highly specific and sensitive methods. We are especially interested in the use of these MS based technologies to quantify very low levels of anti-cancer agents and their metabolites e.g. in situations after local administration where leakage into the systemic circulation is of interest, conceivably causing toxicity.

We review different local administration routes of anticancer agents and discuss, briefly, relevant pharmacologic features of the applicable drugs and their most sensitive bioanalytical assays currently available.

\section{CUTANEOUS ADMINISTERED ANTI-CANCER AGENTS}

Cytotoxic agents, applied to the skin, are usually used for their local effects to treat primary or metastatic skin cancers (Table 1). This administration route is advantageous due to the high local drug concentrations with high local efficacy and low systemic toxicity. However, one must be aware of the regional differences in drug penetration: the face, scalp and scrotum are reasonably more permeable than the leg or a forearm. In those cases, drug penetration may lead to unwanted systemic effects. To study this, ultrasensitive assays are required.

\subsection{Anti-Metabolites}

\subsubsection{5-Fluorouracil}

5-Fluorouracil (5-FU) is a chemotherapeutic agent that can be used both topically and i.v. 5-FU inhibits thymidylate synthetase, which leads to inhibition of DNA synthesis and cell death [8]. 5-FU is enzymatically cleared from plasma to produce dihydro-5-fluorouracil (FUH2), which is the ratelimiting step catalyzed by dihydropyrimidine dehydrogenase (DPD). Two following steps result in the formation of fluoroureidopropionic acid and $\alpha$-fluoro- $\beta$-alanine (FBAL), respectively with release of $\mathrm{CO}_{2}$ and $\mathrm{NH}_{3}$ (Fig. 2) [9]. Bioanalysis of 5-FU and its metabolites is complex due to its hydrophilic nature and the fact that it is a small molecule, making it cumbersome to separate it from endogenous substances and to detect it selectively using HPLC-UV or even HPLC-MS. There are two ultrasensitive methods with a LLOQ of $1 \mathrm{ng} / \mathrm{mL}$. Wang et al. presented an HPLC-MS/MS assay where 5-FU is extracted from plasma using liquidliquid extraction with ethyl acetate and derivatized with 4bromo-methyl-7-methoxycoumarin (BMC) to yield a diderivatized product with a higher molecular weight and lipophilicity, which allowed the chromatographic separation and reduced the background noise observed in the mass 
Table 1. Selected Overview of Cutaneous Administration of Anti-Cancer Agents

\begin{tabular}{|c|c|c|c|c|c|c|c|c|c|}
\hline Drug & $\begin{array}{c}\text { Drug Classifi- } \\
\text { cation }\end{array}$ & Cancer Type & Dose & Matrix & $\begin{array}{c}\text { Metabolites/ } \\
\text { Degradation } \\
\text { Products }\end{array}$ & Method & $\begin{array}{c}\text { LLOQ } \\
(\mathrm{ng} / \mathrm{mL})\end{array}$ & \begin{tabular}{|c|} 
Method \\
Sensitive \\
Enough?*
\end{tabular} & Ref. \\
\hline 5-Fluorouracil & $\begin{array}{l}\text { Anti- } \\
\text { metabolites }\end{array}$ & $\begin{array}{c}\text { Cutaneous } \\
\text { squamous cell } \\
\text { carcinoma, } \\
\text { actinic kerato- } \\
\text { ses }\end{array}$ & $\begin{array}{c}0.04-5 \mathrm{~mL} \\
5 \% 5-\mathrm{FU} \\
\text { cream ( } \\
2-250 \mathrm{mg} \\
5-\mathrm{FU})\end{array}$ & $\begin{array}{l}\text { (i) Human } \\
\text { plasma } \\
\text { (ii) Human } \\
\text { plasma }\end{array}$ & $\begin{array}{c}\mathrm{FUH}_{2}, \mathrm{FUPA} \\
\text { FBAL }\end{array}$ & $\begin{array}{l}\text { (i) GC-MS } \\
\text { (ii) HPLC- } \\
\text { MS/MS }\end{array}$ & $\begin{array}{l}\text { (i) } 1 \\
\text { (ii) } 5\end{array}$ & Yes & $\begin{array}{l}{[11,179,} \\
275-277]\end{array}$ \\
\hline Temozolomide & $\begin{array}{c}\text { DNA alkylating } \\
\text { agent }\end{array}$ & $\begin{array}{c}\text { Malignant } \\
\text { melanoma, } \\
\text { Glioblastoma }\end{array}$ & $\begin{array}{l}20 \mathrm{mg} / \\
\text { mouse/day }\end{array}$ & $\begin{array}{l}\text { Human } \\
\text { plasma }\end{array}$ & $\begin{array}{l}\text { MTIC and } \\
\text { AIC }\end{array}$ & HPLC-UV & 100 & $\mathrm{n} / \mathrm{a}$ & [21] \\
\hline Temozolomide & $\begin{array}{c}\text { DNA alkylating } \\
\text { agent }\end{array}$ & $\begin{array}{c}\text { Malignant } \\
\text { melanoma, } \\
\text { Glioblastoma }\end{array}$ & $\begin{array}{l}20 \mathrm{mg} / \\
\text { mouse/day }\end{array}$ & $\begin{array}{l}\text { Human } \\
\text { urine }\end{array}$ & $\begin{array}{l}\text { MTIC and } \\
\text { AIC }\end{array}$ & HPLC-UV & 2,000 & $\mathrm{n} / \mathrm{a}$ & [22] \\
\hline $\begin{array}{l}\text { MTIC (bioconversion prod- } \\
\text { uct of temozolomide) }\end{array}$ & $\begin{array}{c}\text { DNA alkylating } \\
\text { agent }\end{array}$ & $\begin{array}{l}\text { Malignant } \\
\text { melanoma, } \\
\text { Glioblastoma }\end{array}$ & - & $\begin{array}{l}\text { Rat } \\
\text { plasma/ } \\
\text { Dog } \\
\text { plasma }\end{array}$ & AIC & HPLC-UV & 10 & $\mathrm{n} / \mathrm{a}$ & [23] \\
\hline MTIC & $\begin{array}{c}\text { DNA alkylating } \\
\text { agent }\end{array}$ & $\begin{array}{c}\text { Malignant } \\
\text { melanoma, } \\
\text { Glioblastoma }\end{array}$ & - & $\begin{array}{l}\text { Human } \\
\text { plasma }\end{array}$ & AIC & $\begin{array}{l}\text { HPLC- } \\
\text { MS/MS }\end{array}$ & 10 & $\mathrm{n} / \mathrm{a}$ & $\begin{array}{c}{[23,24,} \\
278]\end{array}$ \\
\hline $\begin{array}{c}\text { AIC (degradation product of } \\
\text { MTIC) }\end{array}$ & $\begin{array}{c}\text { DNA alkylating } \\
\text { agent }\end{array}$ & $\begin{array}{c}\text { Malignant } \\
\text { melanoma, } \\
\text { Glioblastoma }\end{array}$ & - & $\begin{array}{l}\text { Human } \\
\text { Plasma }\end{array}$ & - & HPLC-UV & 50 & $\mathrm{n} / \mathrm{a}$ & [23] \\
\hline $\begin{array}{l}\text { Mechlorethamine (CIM) } \\
\text { hydrochloride (nitrogen } \\
\text { mustard) }\end{array}$ & $\begin{array}{c}\text { DNA alkylating } \\
\text { agent }\end{array}$ & $\begin{array}{c}\text { Cutaneous T- } \\
\text { cell lymphomas, } \\
\text { Langerhans cell } \\
\text { histiocytosis }\end{array}$ & $\begin{array}{l}0.02 \% \\
(2-3 \mathrm{mg} \\
\text { per day })\end{array}$ & $\begin{array}{l}\text { Human } \\
\text { plasma }\end{array}$ & $\begin{array}{l}\text { N7G-DNA } \\
\text { MDEA }\end{array}$ & HPLC-UV & 100 & $\mathrm{n} / \mathrm{a}$ & {$[31]$} \\
\hline $\begin{array}{l}\text { MDEA (hydrolysis product } \\
\text { of nitrogen mustard) }\end{array}$ & $\begin{array}{c}\text { DNA alkylating } \\
\text { agent }\end{array}$ & $\begin{array}{c}\text { Cutaneous } \\
\text { eruptions of } \\
\text { Langerhans' cell } \\
\text { histiocytosis }\end{array}$ & - & $\begin{array}{c}\text { Human } \\
\text { urine }\end{array}$ & - & $\begin{array}{l}\text { HPLC- } \\
\text { MS/MS }\end{array}$ & 1.6 & $\mathrm{n} / \mathrm{a}$ & [279] \\
\hline $\begin{array}{c}\text { Isotretinoin (all-trans RA) } \\
\text { and retinoic acid (13-cis RA) }\end{array}$ & $\begin{array}{l}\text { Retinoids (vi- } \\
\text { tamine) }\end{array}$ & $\begin{array}{l}\text { Cutaneous T- } \\
\text { cell lymphoma }\end{array}$ & $\begin{array}{l}0.2 \mathrm{~g} \text { of } \\
0.05 \% \mathrm{gel} \\
(0.1 \mathrm{mg})\end{array}$ & $\begin{array}{l}\text { Human } \\
\text { plasma }\end{array}$ & $\begin{array}{l}\text { 4-oxo metabo- } \\
\text { lites }\end{array}$ & $\begin{array}{l}\text { HPLC- } \\
\text { PB/MS }\end{array}$ & 0.05 & Yes & $\begin{array}{c}{[34,280,} \\
281]\end{array}$ \\
\hline $\begin{array}{c}\text { Isotretinoin (all-trans RA) } \\
\text { and retinoic acid (13-cis RA) }\end{array}$ & $\begin{array}{l}\text { Retinoids (vi- } \\
\text { tamine) }\end{array}$ & $\begin{array}{l}\text { Cutaneous T- } \\
\text { cell lymphoma }\end{array}$ & $\begin{array}{l}0.2 \mathrm{~g} \text { of } \\
0.05 \% \mathrm{gel} \\
(0.1 \mathrm{mg})\end{array}$ & $\begin{array}{c}\text { Human } \\
\text { serum }\end{array}$ & $\begin{array}{l}\text { 4-oxo metabo- } \\
\text { lites }\end{array}$ & HPLC-UV & 20 & $\mathrm{n} / \mathrm{a}$ & {$[282]$} \\
\hline $\begin{array}{l}\text { All-trans 4-oxo RA and 13- } \\
\text { cis 4-oxo RA (metabolites of } \\
\text { isotretinoin) }\end{array}$ & $\begin{array}{l}\text { Retinoids (vi- } \\
\text { tamine) }\end{array}$ & \begin{tabular}{|} 
Cutaneous T- \\
cell lymphoma
\end{tabular} & - & $\begin{array}{l}\text { Human } \\
\text { plasma }\end{array}$ & - & HPLC-MS & 0.3 & Yes & $\begin{array}{l}{[280,} \\
283]\end{array}$ \\
\hline $\begin{array}{l}\text { All-trans 4-oxo RA and 13- } \\
\text { cis 4-oxo RA (metabolites of } \\
\text { teratogenic) }\end{array}$ & $\begin{array}{l}\text { Retinoids (vi- } \\
\text { tamine) }\end{array}$ & $\begin{array}{l}\text { Cutaneous T- } \\
\text { cell lymphoma }\end{array}$ & - & $\begin{array}{l}\text { Human } \\
\text { serum }\end{array}$ & - & HPLC-UV & 20 & $\mathrm{n} / \mathrm{a}$ & {$[282]$} \\
\hline Toremifene & Anti-hormone & Breast tumor & $\begin{array}{l}0.5-1 \mathrm{mg} \text { per } \\
\text { day/mice }\end{array}$ & $\begin{array}{l}\text { Human } \\
\text { plasma }\end{array}$ & $\begin{array}{l}\text { TOR I, TOR } \\
\text { III, TAM B }\end{array}$ & $\begin{array}{l}\text { HPLC- } \\
\text { fluorescence }\end{array}$ & 20 & No & [39] \\
\hline $\begin{array}{c}\text { N-desmethyl -toremifene } \\
\text { (TOR-I) } \\
\text { (Deaminohy- } \\
\text { droxy)toremifene (TOR III) }\end{array}$ & Anti-hormone & Breast tumor & - & $\begin{array}{l}\text { Human } \\
\text { plasma }\end{array}$ & - & $\begin{array}{c}\text { HPLC- } \\
\text { fluorescence }\end{array}$ & 20 & No & [39] \\
\hline 4 hydroxytamoxifen (4-OHT) & Anti-hormone & Breast tumor & $0.5-2 \mathrm{mg} /$ day & $\begin{array}{l}\text { Human liver } \\
\text { microsomes }\end{array}$ & - & HPLC-UV & 25 & $\mathrm{n} / \mathrm{a}$ & {$[284]$} \\
\hline 4 hydroxytamoxifen (4-OHT) & Anti-hormone & Breast tumor & $0.5-2 \mathrm{mg} /$ day & $\begin{array}{l}\text { Human } \\
\text { plasma }\end{array}$ & - & GC-MS & 0.02 & Yes & {$[41]$} \\
\hline Miltefosine & Anti-hormone & Breast tumor & $\begin{array}{l}1 \text { drop of } \\
6 \% \text { solution } \\
(1.5 \mathrm{mg})\end{array}$ & $\begin{array}{l}\text { Human } \\
\text { plasma }\end{array}$ & - & $\begin{array}{l}\text { HPLC- } \\
\text { MS/MS }\end{array}$ & 4 & $\mathrm{n} / \mathrm{a}$ & $\begin{array}{c}{[46,47,} \\
285]\end{array}$ \\
\hline
\end{tabular}

Abbreviations: HPLC-UV: High performance liquid chromatography coupled with ultraviolet detector; GC-MS: Gas chromatography coupled to mass spectrometry; HPLC-MS: High performance liquid chromatography coupled to mass spectrometry; HPLC-MS/MS: High performance liquid chromatography coupled to tandem mass spectrometry; HPLCPB/MS: High performance liquid chromatography coupled to particle beam mass spectrometry; LLOQ: Lower limit of quantitation; *: Method is sensitive enough when it allows the systemic detection of the locally administered anti-cancer agents; n/a: Not applicable (because no systemic pharmacokinetic studies have been performed or the compound was not measured). 


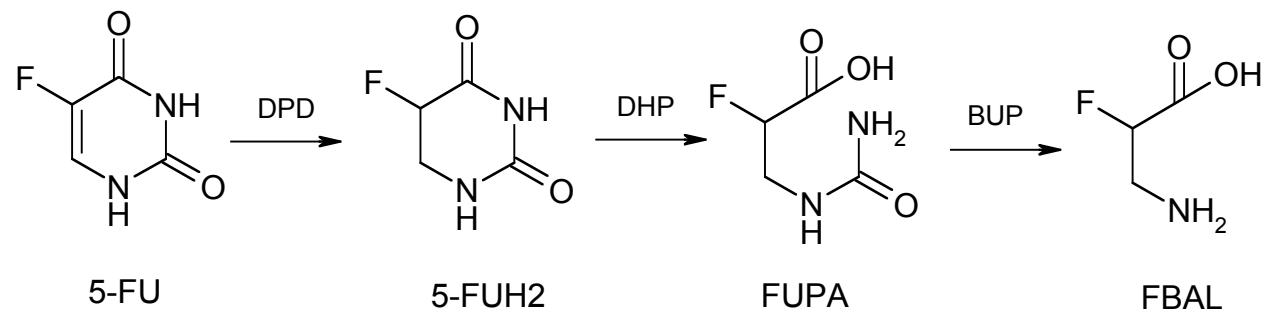

Fig. (2). Metabolic pathway of 5-FU: DPD, Dihydropyrimidine; DHP, Dihydropyrimidinase; BUP, $\beta$-ureidopropionase; $\mathrm{FUH}_{2}$, dihydro-5fluorouracil; FUPA, fluoroureidopropionic acid; FBAL, $\alpha$-fluoro- $\beta$-alanine.

spectrometer with the low weight molecules (Fig. 3) [10]. Derivatized 5-FU eluted from the reversed phase column using an eluent which contained $65 \%$ organic modifier. 500 $\mu \mathrm{L}$ samples aliquots were processed and the LLOQ was $1 \mathrm{ng} / \mathrm{mL}$ using negative APCI mode. Matsushima et al. described another method utilizing gas chromatographynegative ion chemical ionization MS (GC-NICI-MS) method for the analysis of 5-FU (along with tegafur, 5-chloro-2,4dihydroxypyridine and potassium oxonate) in human plasma [11]. This method also yields a LLOQ of $1 \mathrm{ng} / \mathrm{mL}$, but requires $250 \mu \mathrm{L}$ human plasma aliquots, which is 2 times less than required by the method described by Wang et al. However, this method is more cumbersome and requires an extensive sample pretreatment. In this method, tegafur was extracted from plasma using liquid-liquid extraction by means of dichloromethane, followed by the extraction of 5FU with ethyl acetate from the residual layer after extraction of tegafur and conversion into its PFB derivative by addition of pentafluorobenzylbromide and thriethylamine [11]. Consequently, if $500 \mu \mathrm{L}$ of samples aliquots are available, the HPLC-MS/MS method described by Wang is preferred with a LLOQ of $1 \mathrm{ng} / \mathrm{mL}$, due to its simplicity.

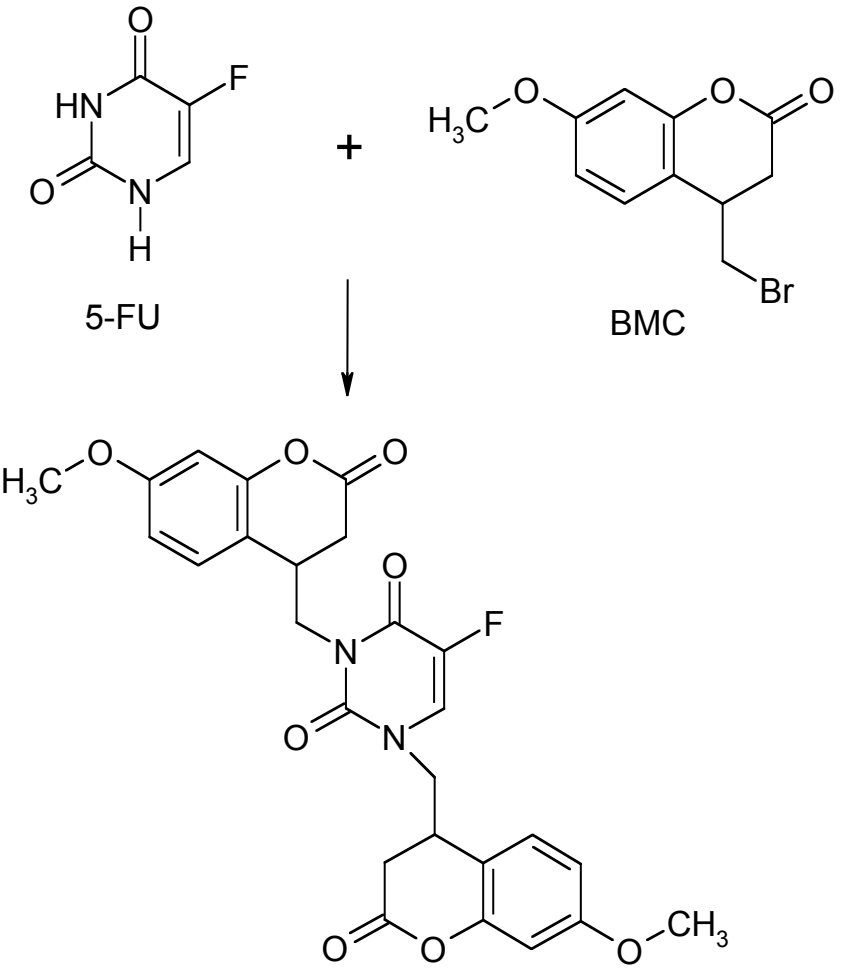

Fig. (3). Derivatization of 5-fluorouracil (5-FU) with 4-bromomethyl-7-methoxycoumarin (BMC).
The 5\% 5-FU formulation was approved as a treatment of actinic keratoses (AK) in the early 1970s. 5-FU has been used to treat localized skin cancers and urological cancers, with good response (around 80-90\%). When applied topically, 5-FU is less toxic than systemic chemotherapy. Usually 5 -FU is applied to premalignant or malignant skin lesions as 5\% Efudix ${ }^{\circledR}$ cream/ointment $[8,12-15]$. The local side effects include pain, irritation, inflammation and soreness. The applied dosage varies greatly from the size of lesional area treated and the thickness of the applied cream. Usually, the dosages of cutaneously applied 5-FU vary between $2 \mathrm{mg}$ and $250 \mathrm{mg}$ [13]. However, there are cases when $5 \% 5$-FU ointment is applied to the total body surface for the treatment of the extensive non-melanoma skin cancer. A case represents a 73-year-old man, who received topical 5-FU 5\% cream twice weekly to the total body using 20 g per application [16]. The treatment period was 6 weeks and the blood samples were taken before, 30, 60, 90, 120, 240 minutes after and $24 \mathrm{~h}$ after application in order to measure the i.v. 5FU levels. Using a HPLC-UV method with LLOQ of 10 $\mathrm{ng} / \mathrm{mL}$ [17], no detectable levels of 5-FU were observed [16]. Although, no systemic toxicity was observed, apparently this method is not sensitive enough to determine the traces of 5-FU in plasma. Yet, with the methods described by Matsushima and Wang with the LLOQ of $1 \mathrm{ng} / \mathrm{mL}$ it might be possible to determine 5-FU levels in the systemic circulation after topical administration.

\subsection{DNA Alkylating Agents}

DNA alkylating agents were the first compounds identified to kill cancer cells. They contain reactive alkyl moieties that can covalently bind to vital cellular components. They form a variety of interstrand cross-linked adducts, that alter DNA structure or function. The nitrogen mustards are the largest class of alkylating agents. The most common site of alkylation is the N-7 position of guanine in the DNA.

\subsubsection{Temozolomide}

Temozolomide is an imidazotetrazine derivative of the alkylating agent dacarbazine (DTIC), which spontaneously degrades in physiological fluid to generate the cytotoxic methylating agent, MTIC (5(3-methyl-1-triazeno)imidazole4-carboxamide), which subsequently fragments to the DNAmethylating agent, methyldiazonium [18-20]. It is believed, that MTIC alkylates the $\mathrm{O}^{6}$ and $\mathrm{N}^{7}$ positions of guanine in the DNA. In this process, MTIC itself is converted to 5(4)aminoimidazole-4(5)-carbozamide (AIC) (Fig. 4) [21-23]. Temozolomide, in addition to nausea and vomiting, causes dose-limiting myelotoxicity following oral administration, and haematological toxicity often led to disrupt treatment. 


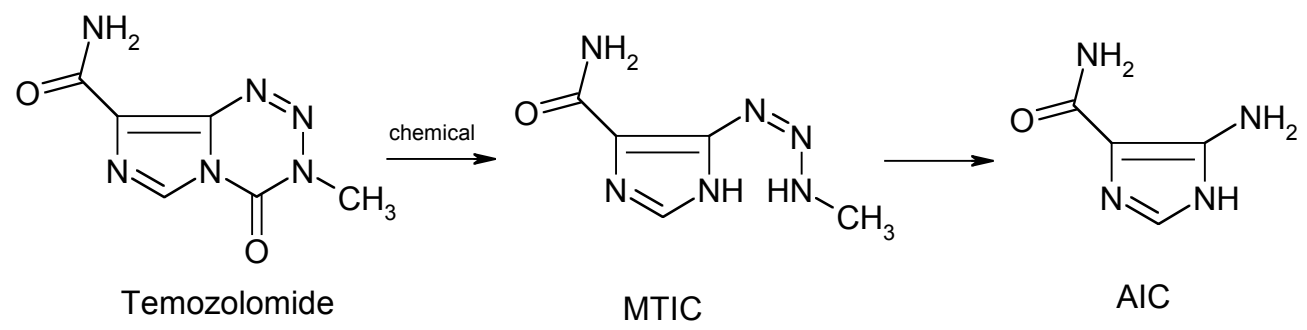

Fig. (4). Metabolism of Temozolomide (MTIC, (5(3-methyl-1-triazeno)imidazole-4-carboxamide; AIC, 5(4)-aminoimidazole-4(5)carbozamide)

Therefore, the cutaneous route of administration was tested recently [18]. Shen et al. presented an HPLC-UV assay to determine temozolomide in human plasma with the lower limit of quantitation (LLOQ) of $200 \mathrm{ng} / \mathrm{mL} .100 \mathrm{mg} \mathrm{C}$ - $^{-}$ endcapped cartridges to extract temozolomide from the plasma and $100 \mu \mathrm{L}$ sample aliquots were used [21]. Hong Kim et al. presented the assay with a LLOQ of $100 \mathrm{ng} / \mathrm{mL}$, where temozolomide is extracted using ethyl acetate followed by separation on a reversed phase C-18 column and quantification by UV absorbance at $316 \mathrm{~nm}$ using $500 \mu \mathrm{L}$ aliquot human plasma [22]. Although the last assay seems more sensitive, 5 times more sample aliquot is required compared to an assay described by Shen [21]. Since it is believed that temozolomide exerts its antitumor activity via its degradation product MTIC, it is important to also determine MTIC plasma concentrations following cutaneous administration of temozolomide to evaluate its systemic exposure and plasma pharmacokinetics [22,24]. MTIC is a highly unstable compound and, consequently, the chosen sample pretreatment is usually a simple protein precipitation on ice with ice-cold reagents followed by immediate analysis. Chowdhury et al. developed an HPLC-MS/MS method for the determination of MTIC in dog and rat plasma with a LLOQ of $10 \mathrm{ng} / \mathrm{mL}$ utilizing only $70 \mu \mathrm{L}$ of dog/rat plasma [23]. Sample purification was achieved by means of a simple protein precipitation with $70 \mu \mathrm{L}$ of methanol and MS was operated in the positive ion mode. Another method, described by Kim et al, utilizes $200 \mu \mathrm{L}$ human plasma and protein precipitation with $100 \mu \mathrm{L}$ methanol [22]. This method was developed using HPLC-UV with a LLOQ for MTIC in human plasma of $10 \mathrm{ng} / \mathrm{mL}$. Although this HPLC-UV method has the same LLOQ for temozolomide as the HPLC-MS/MS method (10 $\mathrm{ng} / \mathrm{mL}$ ), the assay presented by Kim et al. (LC-MS/MS) is relatively more sensitive utilizing only $70 \mu \mathrm{L}$ of plasma instead of $200 \mu \mathrm{L}$. With topical application at a dose of 20 $\mathrm{mg} / \mathrm{mouse} /$ day, the newly synthesized temozolomide hexyl ester, effectively inhibited the tumor growth in mice, inoculated with MV3 human melanoma cells [18]. Although, no study was executed to verify the systemic exposure to temozolomide and MTIC after cutaneous administration, the methods of Kim et al. [22] and Chowdhury et al. [23] with a LLOQ of $10 \mathrm{ng} / \mathrm{mL}$ are probably sensitive enough to determine any temozolomide/MTIC reaching the systemic circulation after cutaneous administration.

\subsubsection{Nitrogen Mustard}

Nitrogen mustard (mechlorethamine hydrochloride, mustine) is an alkylating anti-cancer agent discovered in 1940's and is used in the treatment of Hodgkin's disease,
non-Hodgkin's lymphoma, leukemia, and multiple myeloma $[25,26]$. This compound can alkylate a DNA base or crosslink between two bases (guanine and adenine) of a DNA helix [27]. In urine, nitrogen mustard hydrolyses to Nmethyldiethylamine (MDEA). Others than the intravenous (i.v.) routes have been tested, and mechlorethamine has been particularly successful in a topical treatment of mycosis fungoids (MF) and Langerhans cell histiocytosis (LCH) [25,26,28-30]. Topical nitrogen mustard has been shown to be effective for patients with early stages of MF. There is, however, only one article describing the determination of nitrogen mustard in human plasma [31]. Here, mechlorethamine is treated first with diethyldithiocarbamic acid (DDTC) to form the disubstituted derivative, which is then analyzed by HPLC-UV with a LLOQ of $100 \mathrm{ng} / \mathrm{mL}$ (Fig. 5) [31]. Mass and NMR spectrometry confirmed that one molecule of DDTC reacts with each arm of the nitrogen mustard, displacing a chlorine atom to form a stable disubstituted adduct. The HPLC-UV method is, however, probably not sensitive enough to measure any absorbed nitrogen mustard.

After all, no evidence of systemic toxicity was observed as measured by normal blood count and chemistries. In conclusion, further research has to be executed.

\subsection{Vitamines}

\subsubsection{Isotretinoin}

Isotretinoin, a derivative of retinoic acid (13-cis-retinoic acid), which is a natural derivative of Vitamine A, plays an important role in tissue growth, differentiation and development [32]. However, when administered orally, isotretinoin has some severe side effects, and both isomers of retinoic acid (isotretinoin and tretinoin) and their respective 4-oxo metabolites are teratogenic. Therefore, gel pharmaceutical formulations containing $0.05 \%(\mathrm{w} / \mathrm{w})$ isotretinoin for the cutaneous administration, have been developed $[32,33]$.

Lehman et al. described a highly sensitive assay with a LLOQ for isotretinoin as low as $0.05 \mathrm{ng} / \mathrm{mL}$ human plasma [34]. 0.5-mL aliquots plasma samples were protein precipitated with 2-propanol followed by solid phase extraction. The retinoic acids were derivatized to the pentafluorobenzyl (PFB) ester by the addition of $10 \mu \mathrm{L}$ of neat PFB bromide and $10 \mu \mathrm{L}$ of $10 \mathrm{mg} / \mathrm{mL}$ potassium carbonate in acetonitrilewater $(50: 50, \mathrm{v} / \mathrm{v})$ solution to the solid phase extraction acetonitrile eluate. The chromatographic separation was performed by means of HPLC and the highly sensitive detection was obtained using mass spectrometry particle beam interface (HPLC/PB/MS) [34]. Willoughby and Browner [35] 
<smiles></smiles>

mechlorethamine<smiles>CCN(CC)C(=S)[S-]</smiles>

2 diethyldithiocarbamic acid (DDTC)<smiles>CCN1CCCN(CC)C(=S)SCCN(C)CCSC1=S</smiles>

disubstituted nitrogen mustard adduct

Fig. (5). Proposed reaction mechanism of diethyldithiocarbamic acid with mechlorethamine.

demonstrated promising performance characteristics for a system consisting of an aerosol generator, a desolvation chamber, and a particle beam separator. This design was named MAGIC, but with the commercial development of several variations of MAGIC, became known as a particle beam interface [36]. HPLC/PB/MS has proven to be a valuable tool for the detection of the thermolabile and nonvolatile analytes.

The use of PFB ester derivative and negative chemical ionization using methane as the ionization reagent yielded only one significant negative ion fragment, contributing to the high sensitivity of this method, the carboxylate anion of the parent acid (M-PFB)- This method could not only quantify endogenous retinoic acid plasma levels (between 0.8 and $3.5 \mathrm{ng} / \mathrm{mL}$ ), but also provided the latitude to discriminate very small changes in those levels [34]. The administered amount of isotretinoin in a gel formulation $(0.05 \%$ or 0.5 $\mathrm{mg} / \mathrm{g}$ ) is described to be $0.2 \mathrm{~g}$ [33].

Consequently, if topically administered isotreinoin will exhibit leakage into the systemic circulation, the traces of isotretinoin can quantified by this ultrasensitive method developed by Lehman et al. with a LLOQ of $0.05 \mathrm{ng} / \mathrm{mL}$, al- lowing determination of even the minimal changes in the endogenous levels of isotretinoin [34].

\subsection{Anti-Hormones}

Anti-hormones modify the expression of specific genes and block the action of a hormone on receptor sites.

\subsubsection{Toremifene}

Toremifene is a new triphenylethylene with activity in patients with breast and endometrial cancer [37]. When applied i.v., toremifene is extensively metabolized and over twenty metabolites have been identified, however, the two major metabolites of toremifene, $\mathrm{N}$-desmethyl-toremifene (TOR-I) and (deaminohydroxy)toremifene (TOR III) are present in human plasma in significant quantities and are believed to be active (Fig. 6) [38]. Besides the i.v. administration, toremifene was also tested topically to obtain high concentrations in superficial tumors while minimizing the systemic exposure [37].

Webster et al. described a simple quantitative HPLC determination of toremifene and its major metabolites in human plasma by means of protein precipitation with acetoni-

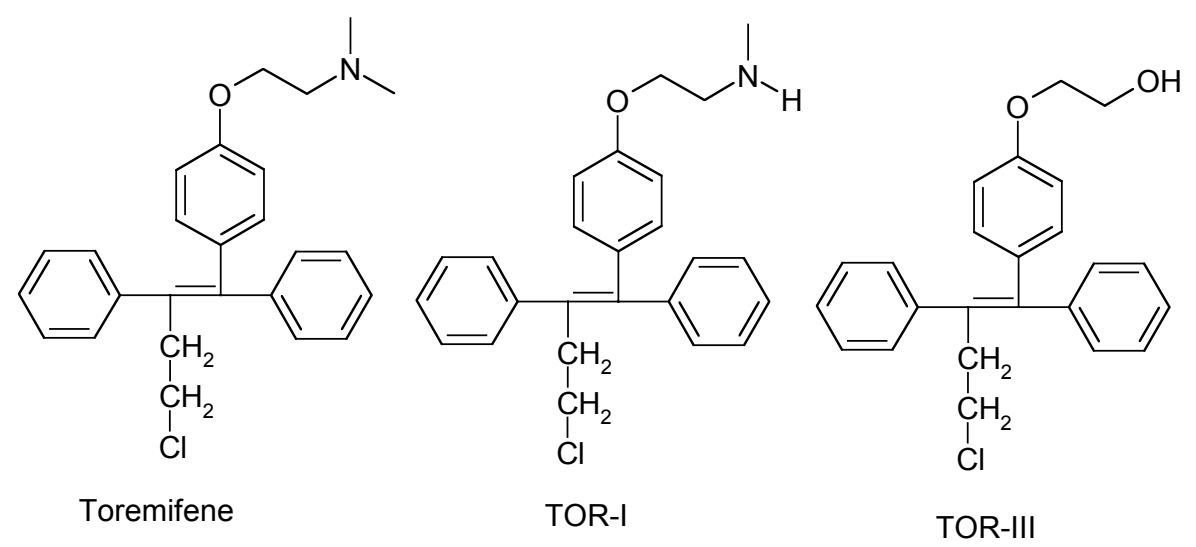

Fig. (6). Structural formulas of toremifene and its two major metabolites TOR-I and TOR-III. 
trile and UV detection with a LLOQ of $100 \mathrm{ng} / \mathrm{mL}$ utilizing $100 \mu \mathrm{L}$ plasma aliquots [38].

Thus far, the most sensitive assay for the determination of toremifene and its major metabolites in human plasma is presented by Holleran et al. [39]. Plasma samples were spiked with nafoxidine, an internal standard, and extracted with $2 \%$ n-butanol in hexane. The aliquots of the extracted plasma components were injected onto a C-18 reversed phase column and eluted isocratically with a mobile phase consisting of water and triethylamine in methanol. The detection was performed by means of fluorescence detection with a LLOQ of $25 \mathrm{ng} / \mathrm{mL}$ for all compounds and the lower limit of detection (LOD) of 8,15 and $5 \mathrm{ng} / \mathrm{mL}$ for toremifene, N-desmethyl-toremifene and 4-hydroxytoremifene, respectively [39].

The distribution and the cytotoxic effects of topically applied toremifene (0.5-1 mg/day for 5 days) in the ultraviolet B (UVB)-induced melanoma model was examined [37]. The topical administration of toremifene yielded high local concentration with minimal systemic distribution. In addition, toremifene exhibited a cytotoxic effect at achievable concentrations in a variety of melanomatous cell lines. In plasma, toremifene could only be detected in one animal out of six, at $16 \mathrm{ng} / \mathrm{mL}$. The authors used the method described by Holleran et al. and the detected $16 \mathrm{ng} / \mathrm{mL}$ is lower that the LLOQ, but higher than LOD. Hence, this method is not sensitive enough to quantify the traces of systemically absorbed tamoxifen in this study. To achieve a greater sensitivity a HPLC-MS/MS technology instead of HPLC-UV and the fluorescence method used here, can possibly provide better results.

\subsubsection{4-Hydroxytamoxifen}

4-Hydroxytamoxifen (4-OHT) is the most active metabolite of tamoxifene, which binds to the estrogen receptor with higher affinity than tamoxifen (Fig. 7) [40]. It was found that the cutaneous application of 4-OHT gel $(0.5,1$ or $2 \mathrm{mg} /$ day $)$ to the skin of the breast produced high and consistent tumor concentrations of 4-OHT and much lower plasma levels. Thus far, there is only one, but a highly sensitive method to determine 4-OHT concentration in human plasma with a LLOQ of $0.02 \mathrm{ng} / \mathrm{mL}$ [41]. The drug and deuterated internal standard (4-OHT D4) were measured by GC/negative chemical ionization MS with methane as the reactant gas. 4OHT and internal standard were isolated from the complex biological matrices using a solid-phase extraction procedure with Extrelut 1 columns. 4-OHT was converted to the fluorinated derivative with pentafluorobenzyl chloride. This assay required $0.5 \mathrm{ml}$ of plasma or $0.5 \mathrm{~g}$ of mammary tissue. The mass spectra showed abundant and stable molecular ions of 4-OHT and 4-OHT-d4, which were generated by electron capture process. This assay showed low relative standard deviation [41]

Recently, a randomized study was performed to analyze whether 4-OHT gel, administered cutaneously on the breast skin, can inhibit the proliferation of malignant breast cells to the same extent as orally administered tamoxifen [40]. Several doses were tested to determine the best ratio efficacy/safety. After the administration of $0.5 \mathrm{mg} /$ day, 1.0 $\mathrm{mg} /$ day and $2.0 \mathrm{mg}$ /day 4-OHT gel, the concentrations of 18 $144,20-84$ and $31-306 \mathrm{pg} / \mathrm{mL}$ of $4-\mathrm{OHT}$ in plasma were measured using the method described above. Consequently, the LLOQ of this ultrasensitive method is sufficient for this application.

\subsubsection{Miltefosine}

Miltefosine (hexadecylphospholine, He-PC) is an alkylphospholine with a long-chain fatty acids-like backbone belonging to a new therapeutic class of cytotoxic agents that are related to phospholipids (Fig. 8) [42]. The cytotoxic effect of miltefosine has been demonstrated in a wide range of tumors. When administered systemically, miltefosine induces major gastrointestinal toxicity. However, when combined with glycerol ethers it is absorbed through the cutaneous tissue and can be delivered topically [42-44]. Thus far, miltefosine proved to be therapeutically active when administered topically in $6 \%$ miltefosine solution against cutaneous metastases from breast cancer [42-45]. The lowest administered dose was 1 drop $(0.025 \mathrm{~mL})$ of $6 \%(60 \mathrm{mg} / \mathrm{mL})$ miltefosine solution, yielding a total dose of $1.5 \mathrm{mg}$. Thus far published HPLC coupled to evaporative light scattering detector (ELSD) analytical method utilizing solid phase extraction as means of sample pretreatment, allowed quantification of miltefosine in human plasma with a LLOQ of $340 \mathrm{ng} / \mathrm{ml}$ [46]. However, recently at our lab, Dorlo et al. succeeded to develop a more sensitive method utilizing a reversed phase HPLC-MS/MS technology with a LLOQ for miltefosine of 4 $\mathrm{ng} / \mathrm{mL}$. Solid phase extraction utilizing Phenyl Bond Elut SPE cartridges was used as means of samples pretreatment and $250 \mu \mathrm{L}$ sample aliquots were processed. [47]. Use of a $0.9 \mathrm{M}$ aqueous acetic acid buffer solution set at $\mathrm{pH} 4.5$ for
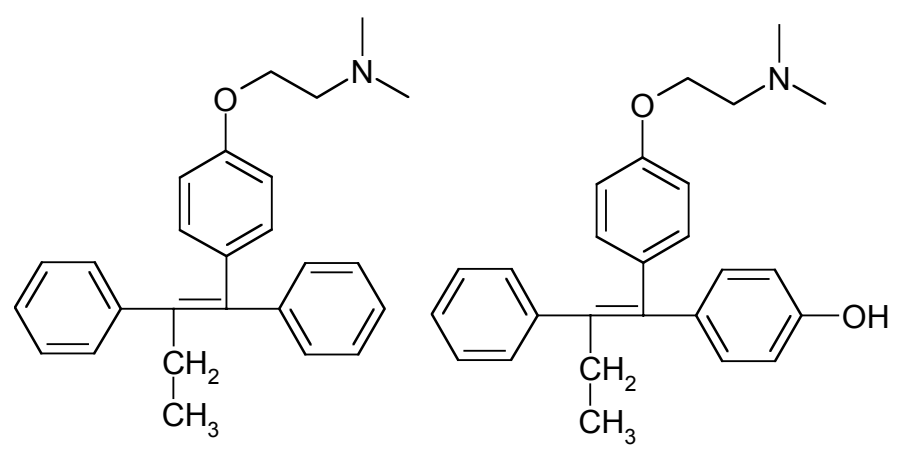

Tamoxifen

4-OHT

Fig. (7). Chemical structures of tamoxifen and its active metabolite 4-hydroxytamoxifen (4-OHT). 
dilution of the samples and conditioning of the solid phase extraction cartridges, resulted in a slightly better recovery compared to the above described method [46] and, more importantly, highly reproducible results. Because the structure of miltefosine lacks any chromophores, it makes UV or fluorescence detection very difficult, and MS detection is an obvious choice offering a sufficiently high sensitivity to measure miltefosine in human plasma [47].<smiles>CC(C)(C)CCOP(=O)([O-])OCC[N+](C)(C)C</smiles>

\section{Miltefosine}

Fig. (8). Structural formula of miltefosine.

\section{OCULAR ADMINISTERED ANTI-CANCER AGENTS}

Anti-cancer agents used to treat eye disorders can be mixed with inactive substances to make a liquid, gel or ointment, so that they can be applied to the eye (Table 2). Ocular agents are almost always only used for their local effects after they are absorbed through the cornea and conjunctiva. However, some of these drugs may then enter the bloodstream and might have unwanted effects on other parts of the body.

\subsection{Anti-Metabolites}

\subsubsection{5-Fluorouracil}

The spectrum of squamous neoplasia of the conjuctiva and cornea ranges from mild to severe epithelial dysplasia, full thickness epithelial involvement (carcinoma in situ) to invasive squamous cell carcinoma. The surgical excision of the neoplastic lesions has been the standard treatment, however due to the high recurrence rate $(15-50 \%)$ after the surgery, other methods of treatment have been investigated and used alone or as an adjunct to surgery [48]. Topical 1\% 5-FU has been shown to be effective in treating conjunctival and corneal intraepithelial neoplasia (CIN); it has been well tolerated and effective method of treatment [48]. The 1\% 5-FU therapeutic formulation was prepared using a preservativefree methylcellulose solution as a vehicle. The sensitive analytical assays to determine 5-FU in human plasma are described in section 3.1.1, however due to the lack of information on the possible plasma levels obtained after the ocular administration of 5-FU, we can not draw any conclusion on the usefulness of these methods for the described clinical application.

\subsection{DNA Alkylating Agents}

\subsubsection{Mitomycin $C$}

Mitomycin C (MMC) is a chemotherapeutic antibiotic isolated from Streptomyces caespitosus. It is an alkylating agent, which causes breakage of single-strand DNA. MMC functions in all phases of the cell cycle, especially in rapid dividing cells. The most significant toxicity of MMC in humans is myelosuppression, confirmed to be delayed and dose-related effect. As a consequence of chemical degradation or quinone reduction three primary metabolites of $\mathrm{MMC}$ can be produced: 2,7-diaminomitosene (2,7-DM) 1,2-cisand 1,2-trans-hydroxy-2,7-diaminomitosene (cis-hydro and trans-hydro) (Fig. 9). The formation of the metabolites is $\mathrm{pH}$-dependant. Moreover, the factors such as oxygen tension and level of free radicals can influence the formation of the metabolites [49].

Over the years there have been numerous HPLC with UV or Photo Diode Array (PDA) detection methods developed

Table 2. Selected Overview of Ocular Administration of Anti-Cancer Agents

\begin{tabular}{|c|c|c|c|c|c|c|c|c|c|}
\hline Drug & $\begin{array}{c}\text { Drug Classi- } \\
\text { fication }\end{array}$ & $\begin{array}{c}\text { Cancer } \\
\text { Type }\end{array}$ & Dose & Matrix & $\begin{array}{c}\text { Metabolites/ } \\
\text { Degradation } \\
\text { Products }\end{array}$ & Method & $\begin{array}{c}\text { LLOQ } \\
(\mathrm{ng} / \mathrm{mL})\end{array}$ & $\begin{array}{l}\text { Method } \\
\text { Sensitive } \\
\text { Enough?* }\end{array}$ & Ref. \\
\hline 5-Fluorouracil & $\begin{array}{c}\text { Anti- } \\
\text { metabolites }\end{array}$ & $\begin{array}{c}\text { Conjunctival } \\
\text { and corneal } \\
\text { intraepithelial } \\
\text { neoplasia }\end{array}$ & $\begin{array}{c}0.06 \mathrm{~mL} 1 \% \\
5-\mathrm{FU} \text { solution } \\
(60 \mu \mathrm{g} 5-\mathrm{FU})\end{array}$ & $\begin{array}{l}\text { (i) Human } \\
\text { plasma } \\
\text { (ii) Human } \\
\text { plasma }\end{array}$ & $\mathrm{FUH}_{2}$, FUPA, FBAL & $\begin{array}{l}\text { (i) GC-MS } \\
\text { (ii) HPLC- } \\
\text { MS/MS }\end{array}$ & $\begin{array}{l}\text { (i) } 1 \\
\text { (ii) } 5\end{array}$ & $\mathrm{n} / \mathrm{a}$ & $\mid \begin{array}{c}{[11,} \\
179 \\
275-277]\end{array}$ \\
\hline Mitomycin & $\begin{array}{c}\text { DNA alkylat- } \\
\text { ing agent }\end{array}$ & $\begin{array}{c}\text { Conjunctival } \\
\text { and corneal } \\
\text { intraepithelial } \\
\text { neoplasia }\end{array}$ & $\begin{array}{c}1 \text { drop of } \\
0.002 \% \text { to } \\
0.04 \% \mathrm{MMC} \\
\text { in sterile } \\
\text { distilled } \\
\text { water }\end{array}$ & $\begin{array}{l}\text { (i) Human } \\
\text { plasma } \\
\text { (ii) Human } \\
\text { urine } \\
\text { (iii) Human } \\
\text { tumor } \\
\text { (iv)Human } \\
\text { humor } \\
\text { (v) Human } \\
\text { ocular tissue }\end{array}$ & $\left|\begin{array}{c}\text { 2,7-diaminomitosene } \\
\text { 1,2-cis-hydroxy- } \\
\text { 2,7-diaminotoserone }\end{array}\right|$ & $\begin{array}{l}\text { (i) HPLC- } \\
\text { UV } \\
\text { (ii) HPLC- } \\
\text { UV } \\
\text { (iii) HPLC- } \\
\text { PDA } \\
\text { (iv) HPLC- } \\
\text { UV } \\
\text { (v) HPLC- } \\
\text { PDA }\end{array}$ & $\begin{array}{l}\text { (i) } 0.5 \\
\text { (ii) } 1 \\
\text { (iii) } 20 \mathrm{ng} / \mathrm{g} \\
\text { (iv) } 6.25 \\
\text { (v) } 1\end{array}$ & $\mathrm{n} / \mathrm{a}$ & {$[49-59]$} \\
\hline $\begin{array}{l}\text { 2,7-diaminomitosene } \\
\text { 1,2-cis-hydroxy- } \\
\text { 2,7-diaminotoserone }\end{array}$ & - & - & - & $\begin{array}{l}\text { Human } \\
\text { tumor }\end{array}$ & - & HPLC-UV & 100 & $\mathrm{n} / \mathrm{a}$ & [49] \\
\hline
\end{tabular}

Abbreviations: HPLC-UV: High performance liquid chromatography coupled with ultraviolet detector; HPLC-PDA: High performance liquid chromatography coupled with photodiode array detector; GC-MS: Gas chromatography coupled to mass spectrometry; HPLC-MS/MS: High performance liquid chromatography coupled to tandem mass spectrometry; LLOQ: Lower limit of quantitation; *: Method is sensitive enough when it allows the systemic detection of the locally administered anti-cancer agents; n/a: Not applicable (because no systemic pharmacokinetic studies have been performed or the compound was not measured). 
<smiles>COC12C(C)CN1C1C(=O)C(C)=C(N)C(=O)C1C2COC(N)=O</smiles><smiles>CC1=C(N)C(=O)C2C(COC(N)=O)=C3CC(N)CN3C2C1=O</smiles>

2,7-DM<smiles>CC1=C(N)C(=O)C2C(COC(N)=O)=C3C(O)[C@H](N)CN3C2C1=O</smiles>
cis-hydroxy<smiles>CC1=C(N)C(=O)C2C(COC(N)=O)=C(O)C(N)CN2C1=O</smiles>

Fig. (9). Structural formula of Mitomycin C (MMC).

for the quantification of mitomycins in various biological matrices [49-59]. Paroni et al. described an ultra sensitive method for the determination of MMC in human plasma with the LLOQ of $0.5 \mathrm{ng} / \mathrm{mL}$ [57]. Relatively high amount of $1000 \mu \mathrm{L}$ sample aliquots were processed using solid-phase extraction under vacuum and the injection volume of 100 $200 \mu \mathrm{L}$ into the HPLC column is utilized. Chromatographic analysis was performed on a reversed-phase $\mathrm{C} 18$ column and MMC was detected by means of the UV detection set at 365 $\mathrm{nm}$ [57]. Dalton et al. described a more simple HPLC-UV method for MMC in plasma with the LLOQ of $0.5 \mathrm{ng} / \mathrm{mL}$ [53]. $1000 \mu \mathrm{L}$ sample aliquots were mixed with $10 \mu \mathrm{L}$ of internal standard porfiromycin $(1.07 \mathrm{mg}$ in $0.5 \mathrm{M}$ phosphate buffer $\mathrm{pH} 7$ ) and $90 \mu \mathrm{L} 2.0 \mathrm{M}$ phosphate buffer $\mathrm{pH}$ 7. MMC and its internal standard were extracted from human plasma with $10 \mathrm{~mL}$ ethyl acetate and $50 \mu \mathrm{L}$ was injected into the HPLC. Dalton et al. describe the difficulties associated with the sample pretreatment of MMC. The tight binding of the MMC to the glass tube under vacuum conditions was observed during the extraction. This problem was solved by first evaporating ethylacetate with dissolved MMC in 10-ml disposable glass tube to dryness under a stream of nitrogen at ambient temperature, followed by rinsing the used glass tube with two separate $100 \mu \mathrm{L}$ aliquots of methanol, transferring the methanol fraction to an eppendorf tube and evaporating again in the vortex vacuum evaporator [53].

Topical MMC has been successfully used in the treatment of recurrent conjunctival-corneal intraepithelial neoplasia (CCIN) since 1994 with reported success rates of 85$100 \%[60,61]$. Various concentrations and durations of the treatment have been tested: from $0.002 \%$ to $0.04 \% \mathrm{MMC}$ in sterile distilled water. No study has been executed where systemical concentrations of topically administered MMC were determined. The ultrasensitive assay described by
Dalton et al. may be sufficiently sensitive to measure any $\mathrm{MMC}$ in the systemic circulation.

\section{OTHER TOPICALLY ADMINISTERED ANTI- CANCER AGENTS}

\subsection{Ear}

\subsubsection{Anti-Metabolites}

\subsubsection{5-Fluorouracil}

Retraction and abnormal proliferation of the eardrum epithelium are believed to consist of pathogenic processes of cholesteatoma [14]. 5\% 5-FU topical cream has been effective ( $88 \%$ of the 50 patients) with no serious side effects [14]. $2-3 \mathrm{~mm}^{3}(0.002-0.003 \mathrm{~mL})$ of $5 \% 5-\mathrm{FU}(50 \mathrm{mg} / \mathrm{mL})$ cream is applied on the outer surface of cholesteatoma transmeatally under the microscope 2 to 5 times with interval of 2 weeks (Table 3) [14]. No study was executed where the systemic exposure was measured.

\subsection{Pharynx}

\subsubsection{Anti-Metabolites}

\subsubsection{5-Fluorouracil}

There is only one case reported when $5 \% 5$-FU cream is used to treat squamous cell carcinoma recurrence on a reconstructive free flap in the pharynx [8]. The protocol consisted of five applications of ribbon gauze coated with $20 \mathrm{~g}$ of $5 \%$ Efudix ${ }^{\circledR}(50 \mathrm{mg} / \mathrm{g} ; 5-\mathrm{FU}$ ointment $)$ at three-weekly intervals. The patient experienced no side effects of the treatment and 28 months post-treatment was still clinically and histologically disease-free. The administered dose was $1,000 \mathrm{mg}$. Although, no study was executed to establish the systemic exposure to 5-FU after this topical administration, with the methods described by Matsushima and Wang with a LLOQ 
Table 3. Selected Overview of Other Topical Administration Routes of Anti-Cancer Agents

\begin{tabular}{|c|c|c|c|c|c|c|c|c|c|}
\hline Drug & $\begin{array}{c}\text { Drug Classifica- } \\
\text { tion }\end{array}$ & $\begin{array}{c}\text { Cancer Type and } \\
\text { Administration } \\
\text { Route }\end{array}$ & Dose & Matrix & $\begin{array}{c}\text { Metabolites/ } \\
\text { Degradation } \\
\text { Products }\end{array}$ & Method & $\begin{array}{c}\text { LLOQ } \\
(\mathrm{ng} / \mathrm{mL})\end{array}$ & $\begin{array}{c}\text { Method } \\
\text { Sensitive } \\
\text { Enough?* }\end{array}$ & Ref. \\
\hline 5-Fluorouracil & Anti-metabolites & $\begin{array}{c}\text { Conjunctival and } \\
\text { corneal intraepi- } \\
\text { thelial neoplasia } \\
\text { Ear }\end{array}$ & $\begin{array}{l}0.002-0.003 \mathrm{~mL} \text { of } 5 \% \\
\text { cream }(100-150 \mu \mathrm{g})\end{array}$ & $\begin{array}{l}\text { (i) Human } \\
\text { plasma } \\
\text { (ii) Human } \\
\text { plasma }\end{array}$ & $\begin{array}{l}\mathrm{FUH}_{2}, \\
\text { FUPA, } \\
\text { FBAL }\end{array}$ & $\begin{array}{l}\text { (i) GC-MS } \\
\text { (ii) HPLC- } \\
\text { MS/MS }\end{array}$ & $\begin{array}{l}\text { (i) } 1 \\
\text { (ii) } 5\end{array}$ & $\mathrm{n} / \mathrm{a}$ & \begin{tabular}{|c|}
{$[11$,} \\
179, \\
$275-277]$
\end{tabular} \\
\hline 5-Fluorouracil & Anti-metabolites & $\begin{array}{c}\text { Recurrent } \\
\text { squanous cell } \\
\text { carcinoma in the } \\
\text { neopharynx } \\
\text { Pharynx }\end{array}$ & $\begin{array}{c}20 \mathrm{~g} \text { of } 5 \% 5-\mathrm{FU} \\
\text { ointment }(1000 \mathrm{mg})\end{array}$ & $\begin{array}{l}\text { (i) Human } \\
\text { plasma } \\
\text { (ii) Human } \\
\text { plasma }\end{array}$ & $\begin{array}{l}\mathrm{FUH}_{2}, \\
\text { FUPA, } \\
\text { FBAL }\end{array}$ & $\begin{array}{l}\text { (i) GC-MS } \\
\text { (ii) HPLC- } \\
\text { MS/MS }\end{array}$ & $\begin{array}{l}\text { (i) } 1 \\
\text { (ii) } 5\end{array}$ & $\mathrm{n} / \mathrm{a}$ & $\left|\begin{array}{c}{[11,179} \\
275-277]\end{array}\right|$ \\
\hline $\begin{array}{l}\text { bleomycin } \\
A_{2} \text { and } B_{2}\end{array}$ & Antibiotics & $\begin{array}{l}\text { Squamous cell } \\
\text { carcinomas } \\
\text { Mouth }\end{array}$ & $\begin{array}{l}\text { Pledget of cotton } \\
\text { soaked in } 1 \% \text { Bleomy- } \\
\text { cin solution }\end{array}$ & Human plasma & $\begin{array}{l}\text { Deamido- } \\
\text { bleomycin }\end{array}$ & $\begin{array}{l}\text { (i) HPLC- } \\
\text { UV }\end{array}$ & 70 & $\mathrm{n} / \mathrm{a}$ & [62] \\
\hline
\end{tabular}

Abbreviations: HPLC-UV: High performance liquid chromatography coupled with ultraviolet detector; GC-MS: Gas chromatography coupled to mass spectrometry; HPLC-MS/MS: High performance liquid chromatography coupled to tandem mass spectrometry; LLOQ: Lower limit of quantitation; *: Method is sensitive enough when it allows the systemic detection of the locally administered anti-cancer agents; $n$ /a: Not applicable (because no systemic pharmacokinetic studies have been performed or the compound was not measured).

of $1 \mathrm{ng} / \mathrm{mL}$ it might be possible to determine traces of $5-\mathrm{FU}$ in the systemic circulation.

\subsection{Mouth}

\subsubsection{Antitumor antibiotics}

\subsubsection{Bleomycin}

Bleomycin is an antitumor antibiotic drug isolated from Streptomyces verticillus consisting of bleomycin A2 and B2 (Fig. 10). Its cytotoxic activities are believed to be the result from the effect of the drug on physical DNA integrity: DNA binding and DNA cleaving are thought to be the two essential steps in the cytotoxic process. The aminopeptidase Blike enzyme Bleomycin hydrolase, acts on the carboxamide group of the aminoalanine moiety of bleomycin converting it into its inactive metabolite deamido-bleomycin. This inactivation of bleomycin has been shown to be an important step in limiting its antitumor activity [62]. Thus far, there is only one HPLC method for the quantitative determination and extraction of bleomycin (A2 and B2) from biological matrix (human plasma) with a LLOQ of $70 \mathrm{ng} / \mathrm{mL}$ [62]. In this assay, bleomycin in $300 \mu \mathrm{L}$ plasma aliquots was purified from plasma components by a double protein precipitation step with trichloroacetic acid (TCA) containing $1 \mathrm{mM} \mathrm{CuSO}_{4}$ to improve the HPLC peak performance. The two supernatants were mixed and $100 \mu \mathrm{L}$ was twice injected into the reversed phase HPLC coupled with fluorescence detection, which was more sensitive than previously described HPLC-UV techniques [62].

Topical application of $1 \%$ bleomycin in dimethylsulfoxide (DMSO) has been evaluated in clinical trials, resulting in regression and resolution of leukoplakia [63]. The treatment solutions were applied to the involved area (tongue, lip, etc) by soaking pledgets of cotton in the solution with continuous application to the area for $5 \mathrm{~min}$, once daily for 14 days. No plasma samples were measured to determine whether the

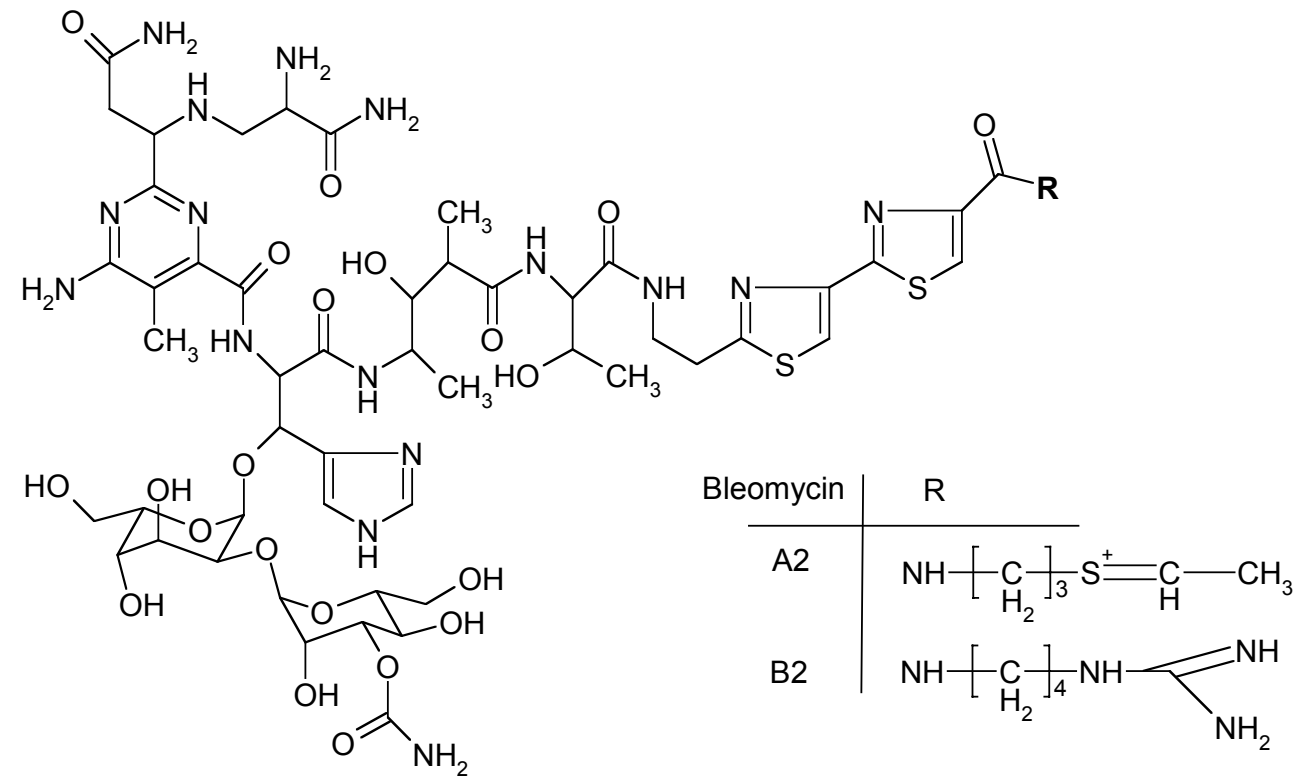

Fig. (10). Structure of Bleomycin A2 and B2. 
topically applied bleomycin may have passed into the systemic circulation. However, the bioanalytical assay with a LLOQ of $70 \mathrm{ng} / \mathrm{mL}$, described above, might be sensitive enough to determine systemic bleomycin after the topical application of high dosages. More research is warranted.

\section{INTRAPERITONEAL ADMINISTERED ANTI- CANCER AGENTS}

Intraperitoneal (i.p.; administration into the abdomen) chemotherapy is used as means of improving the selectivity of chemotherapy of intra-abdominal tumors, including ovarian, gastro-intestinal, pancreatic and colorectal cancers (Table 4) [64-67]. Dedrick et al. suggested that i.p. administered agents would allow much greater peritoneal drug exposure and lesser systemic exposure [68]. Most of the investigations have indeed shown that i.p. drug administration results in large favorable concentration differences between the peritoneal perfusate and blood for a variety of agents [69]. The pharmacological advantage of i.p. therapy is an exposure of the i.p. disease to extremely high concentrations of anticancer drug while minimizing the systemic toxicity. For example, in the case of ovarian cancer, i.p. therapy appears to be a reasonable therapeutic approach, and it has been investigated for years [70].

\subsection{Anti-Metabolites}

\subsubsection{Methotrexate}

Methotrexate (MTX) acts as an antimetabolite and is commonly used for the treatment of various malignant diseases, such as acute leukemia, osteosarcoma, non-Hodgkin lymphoma and breast carcinoma. MTX is converted to 7hydroxymethotrexate (7OH-MTX), which is around 200 times less cytotoxic that MTX (Fig. 11). MTX is a polar, nonvolatile and thermally unstable compound, therefore, the analysis of this compound is quite a challenge. $7 \mathrm{OH}-\mathrm{MTX}$ is less polar compared to MTX due to an intra-molecular bonding between the hydroxyl and one of the carboxylic acid groups. With the introduction of the electrospray ionization MS, the analysis of MTX became possible and several methods have been developed and published [71-74]. A quite elegant method is presented by Steinborner and Henion, involving the semirobotic liquid-liquid extraction in deep-well 96well plates and detection of MTX and 7OH-MTX by means of positive ion turbo-ionspray selected reaction monitoring mass spectrometry (SRM LC/MS) [71]. The sample pretreatment time was reasonably short: 384 samples could be processed in only $90 \mathrm{~min}$ (four 96 -well plates). The $200 \mu \mathrm{L}$ sample aliquots were first protein precipitated with $500 \mu \mathrm{L}$ acetonitrile followed by liquid-liquid extraction with chloroform. All steps were performed in 96-well plates and were automated [75]. A dual column system, consisting of a trapping column configuration and an analytical column, was used to concentrate the analytes and to separate it from matrix components. $80 \mu \mathrm{L}$ aliquots of the aqueous layer were used to be injected onto the trapping column. A small, $1 \mathrm{~mm}$ internal diameter analytical column was employed to achieve improved electrospray HPLC-MS sensitivity, with as result a LLOQ of $0.1 \mathrm{ng} / \mathrm{mL}$ for MTX and $0.3 \mathrm{ng} / \mathrm{mL}$ for $7 \mathrm{OH}-\mathrm{MTX}$ [75].

i.p. administration of MTX has been investigated in mice and rats in combination with i.v. administration of antidrug antibodies (or fragments; collectively abbreviated as ADAb).
The i.p administered dose in animals varied between 1.9 and $10 \mathrm{mg} / \mathrm{kg}$ animal, which was well tolerated [64,69]. Interestingly, the pharmacokinetics of MTX given i.v. or i.p. was similar and no plasma protein binding was observed and the lowest detectable concentrations of approximately $3 \mu \mathrm{g} / \mathrm{mL}$ were yielded [69]. Consequently, the currently available method for the determination of MTX in human plasma with the LLOQ of $0.1 \mathrm{ng} / \mathrm{mL}$ is very adequate for this application.

\subsubsection{5-Fluorouracil}

Uptake of 5-FU in tumor was higher when 5-FU was given i.p. compared to i.v. in a rat model. Moreover, it was found that a considerable uptake of 5-FU in the lymphatic vessels and lymph nodes was observed in the abdominal cavity in pigs. Based on these findings, and to investigate the safety, toxicity and efficacy of i.p. 5-FU, phase I/II study with i.p. 5-FU in non-resectable pancreatic cancer was executed [76-80]. Between 1994 en 2003, 68 patients with nonresectable pancreatic cancer TNM stages III and IV, were enrolled to receive i.p. 5-FU instillation of $750-1500 \mathrm{mg} / \mathrm{m}^{2}$. Although the systemic concentration of 5-FU after i.p. administration is low due to an eighty percent elimination in the first passage through the liver, it could still lead to dose limiting toxicity [76]. The authors concluded that the treatment was well tolerated; tumor response was $4.4 \%$ and median survival time 8 months. The lowest plasma levels of 5FU detected were approximately $60 \mathrm{ng} / \mathrm{mL}$ using an assay with a LLOQ of $6.6 \mathrm{ng} / \mathrm{mL}$ [76]. Therefore, this and the ultrasensitive assay described in section 3.3.1, can provide accurate data on the systemic leakage of i.p. administered 5FU.

\subsection{DNA Alkylating Agents}

\subsubsection{Mitomycin C}

Verwaal et al. performed a phase III study with patients who had carcinomatosis from colorectal cancer [81]. Patients who received cytoreduction plus hyperthermic intraoperative i.p. MMC chemotherapy had a median survival of 22.3 months compared to 12.6 for patients treated by palliative surgery plus systemic chemotherapy $(\mathrm{P}=0.032)$ [81,82]. Therefore, Sugarbaker et al. executed a study with i.p. MMC to provide data regarding the effect of volume of chemotherapy solution on the pharmacokinetics of i.p. chemotherapy. The dose of MMC administered to 48 patients was 12.5 $\mathrm{mg} / \mathrm{m}^{2}$ in male and $10 \mathrm{mg} / \mathrm{m}^{2}$ in female [82].

Blood samples were obtained every 15 minutes for 90 minutes and the last sample was obtained at 120 minutes. Sugarbaker et al. concluded that between $55.7( \pm 9.8) \%$ and $82( \pm 4.4) \%$ of MMC was cleared from the peritoneal cavity after 90 minutes, depending on the volume of the chemotherapy. The lowest determined concentrations in plasma were approximately $70 \mathrm{ng} / \mathrm{mL}$, obtained using an analytical method with a LLOQ of $5 \mathrm{ng} / \mathrm{mL}$ [52]. Consequently, using the ultrasensitive method for the determination of MMC in human plasma described in section 4.3.1, accurate pharmacokinetic curves can be obtained and the leakage of MMC into the systemic circulation can be quantified.

\subsubsection{Melphalan}

Melphalan is an antineoplastic alkylating agent used in the treatment of multiple myeloma, ovarian carcinoma, and 
Table 4. Selected Overview of Intraperitoneal Administration of Anti-Cancer Agents

\begin{tabular}{|c|c|c|c|c|c|c|c|c|c|}
\hline Drug & $\begin{array}{c}\text { Drug Classifi- } \\
\text { cation }\end{array}$ & Cancer Type & Dose & Matrix & \begin{tabular}{|c|} 
Metabo- \\
lites/Degradatio \\
n Products
\end{tabular} & Method & $\begin{array}{c}\text { LLOQ } \\
(\mathbf{n g} / \mathbf{m L})\end{array}$ & $\begin{array}{l}\text { Is the } \\
\text { Method } \\
\text { Sensitive } \\
\text { Enough? }\end{array}$ & Ref. \\
\hline Methotrexate & Antimetabolites & $\begin{array}{l}\text { Peritoneal } \\
\text { tumors }\end{array}$ & \begin{tabular}{|l|}
$1.9 \mathrm{mg} / \mathrm{kg}$ \\
in $\mathrm{rat} / \mathrm{mice}$
\end{tabular} & Human plasma & $\begin{array}{c}\text { 7-hydroxy } \\
\text { methotrexate }\end{array}$ & HPLC-MS/MS & 0.1 & Yes & {$[71,73]$} \\
\hline Methotrexate & Antimetabolites & $\begin{array}{c}\text { Peritoneal } \\
\text { tumors }\end{array}$ & \begin{tabular}{|l|}
$1.9 \mathrm{mg} / \mathrm{kg}$ \\
in rat $/ \mathrm{mice}$
\end{tabular} & Human urine & $\begin{array}{c}\text { 7-hydroxy } \\
\text { methotrexate }\end{array}$ & HPLC-MS/MS & 0.4 & $\mathrm{n} / \mathrm{a}$ & {$[72,74]$} \\
\hline 5-Fluorouracil & Antimetabolites & $\begin{array}{l}\text { Peritoneal } \\
\text { tumors }\end{array}$ & $\begin{array}{c}750-1500 \\
\mathrm{mg} / \mathrm{m}^{2}\end{array}$ & $\begin{array}{l}\text { (i) Human plasma } \\
\text { (ii) Human plasma }\end{array}$ & $\begin{array}{l}\mathrm{FUH}_{2}, \text { FUPA, } \\
\text { FBAL }\end{array}$ & $\begin{array}{l}\text { (i) GC-MS } \\
\text { (ii) HPLC- } \\
\text { MS/MS }\end{array}$ & $\begin{array}{l}\text { (i) } 1 \\
\text { (ii) } 5\end{array}$ & Yes & $\begin{array}{l}{[11,179,} \\
275-277]\end{array}$ \\
\hline Mitomycin C & $\begin{array}{c}\text { DNA alkylating } \\
\text { agent }\end{array}$ & $\begin{array}{c}\text { Bladder cance } \\
\text { rs }\end{array}$ & $\begin{array}{c}12.5 \\
\mathrm{mg} / \mathrm{m}^{2} \text { in } \\
\text { male and } \\
10 \mathrm{mg} / \mathrm{m}^{2}\end{array}$ & $\begin{array}{l}\text { (i) Human plasma } \\
\text { (ii) Human urine } \\
\text { (iii) Human tumor } \\
\text { (iv) Human humor } \\
\text { (v) Human ocular } \\
\text { tissue }\end{array}$ & \begin{tabular}{|c}
$2,7-$ \\
diaminomitosene \\
1,2-cis-hydroxy- \\
$2,7-$ \\
diaminotoserone
\end{tabular} & $\begin{array}{l}\text { (i) HPLC-UV } \\
\text { (ii) HPLC-UV } \\
\text { (iii) HPLC- } \\
\text { PDA } \\
\text { (iv) HPLC-UV } \\
\text { (v) HPLC-PDA }\end{array}$ & $\begin{array}{l}\text { (i) } 0.5 \\
\text { (ii) } 1 \\
\text { (iii) } 20 \mathrm{ng} / \\
\text { (iv) } 6.25 \\
\text { (v) } 1\end{array}$ & Yes & [49-59] \\
\hline \begin{tabular}{|c|} 
2,7-diaminomitosene \\
1,2-cis-hydroxy- \\
2,7-diaminotoserone
\end{tabular} & - & - & - & Human tumor & - & HPLC-UV & 100 & $\mathrm{n} / \mathrm{a}$ & [49] \\
\hline Melphalan & $\begin{array}{c}\text { DNA alkylating } \\
\text { agent }\end{array}$ & \begin{tabular}{|c|} 
Multiple \\
myeloma, \\
ovarian can- \\
cer, malignant \\
melanoma
\end{tabular} & $70 \mathrm{mg} / \mathrm{m} 2$ & Human plasma & $\begin{array}{l}\text { Monohydroxy- } \\
\text { melphalan } \\
\text { (L-MOH) } \\
\text { Dihydoxy- } \\
\text { melphalan } \\
\text { (L-DOH) }\end{array}$ & HPLC-MS/MS & 2 & Yes & [91] \\
\hline Melphalan & $\begin{array}{c}\text { DNA alkylating } \\
\text { agent }\end{array}$ & \begin{tabular}{|} 
Multiple \\
myeloma, \\
ovarian can- \\
cer, malignant \\
melanoma
\end{tabular} & $70 \mathrm{mg} / \mathrm{m}^{2}$ & Human brain & $\begin{array}{l}\text { Monohydroxy- } \\
\text { melphalan } \\
\text { (L-MOH) } \\
\text { Dihydoxy- } \\
\text { melphalan } \\
\text { (L-DOH) }\end{array}$ & HPLC-UV & 25 & $\mathrm{n} / \mathrm{a}$ & [88] \\
\hline L-DOH & $\begin{array}{c}\text { DNA alkylating } \\
\text { agent }\end{array}$ & - & - & Human plasma & - & HPLC-UV & 500 & $\mathrm{n} / \mathrm{a}$ & {$[83,286]$} \\
\hline L-MOH & $\begin{array}{c}\text { DNA alkylating } \\
\text { agent }\end{array}$ & - & - & Human plasma & - & HPLC-UV & 1,400 & $\mathrm{n} / \mathrm{a}$ & [286] \\
\hline Thiotepa & $\begin{array}{c}\text { DNA alkylating } \\
\text { agent }\end{array}$ & $\begin{array}{l}\text { Ovarian } \\
\text { cancer }\end{array}$ & $\begin{array}{c}30 \mathrm{mg} / \mathrm{m}^{2} \\
\text { to } 80 \\
\mathrm{mg} / \mathrm{m}^{2}\end{array}$ & Human plasma & $\begin{array}{c}\text { Tepa } \\
\text { Thiotepa- } \\
\text { mercapturate }\end{array}$ & HPLC-MS/MS & 5 & Yes & {$[96,97]$} \\
\hline Tepa & $\begin{array}{c}\text { DNA alkylating } \\
\text { agent }\end{array}$ & $\begin{array}{l}\text { Ovarian } \\
\text { cancer }\end{array}$ & & Human plasma & - & HPLC-MS/MS & 5 & $\mathrm{n} / \mathrm{a}$ & [96] \\
\hline Cisplatin & $\begin{array}{l}\text { Platinum anti- } \\
\text { cancer drugs }\end{array}$ & $\begin{array}{c}\text { Ovarian can- } \\
\text { cer }\end{array}$ & $100 \mathrm{mg} / \mathrm{m}^{2}$ & $\begin{array}{c}\text { Human plasma } \\
\text { ultrafiltrate }\end{array}$ & $\begin{array}{l}\text { Monohydrated } \\
\text { cisplatin } \\
\text { Dihydrated cis- } \\
\text { platin }\end{array}$ & HPLC-ICP-MS & 2 & Yes** & {$[109,114]$} \\
\hline Carboplatin & $\begin{array}{l}\text { Platinum anti- } \\
\text { cancer drugs }\end{array}$ & $\begin{array}{c}\text { Small hepato- } \\
\text { cellular carci- } \\
\text { noma. }\end{array}$ & $400 \mathrm{mg} / \mathrm{m}^{2}$ & $\begin{array}{c}\text { Rat plasma ultrafil- } \\
\text { trate }\end{array}$ & & HPLC-MS & 70 & Yes** & [122] \\
\hline Carboplatin & $\begin{array}{l}\text { Platinum anti- } \\
\text { cancer drugs }\end{array}$ & \begin{tabular}{|c|}
$\begin{array}{c}\text { Small hepato- } \\
\text { cellular carci- } \\
\text { noma. }\end{array}$ \\
\end{tabular} & $400 \mathrm{mg} / \mathrm{m}^{2}$ & Tumor tissue & & HPLC-MS & 30 & $\mathrm{n} / \mathrm{a}$ & {$[122]$} \\
\hline Oxaliplatin & $\begin{array}{l}\text { Platinum anti- } \\
\text { cancer drugs }\end{array}$ & $\begin{array}{c}\text { Small hepato- } \\
\text { cellular carci- } \\
\text { noma. }\end{array}$ & $460 \mathrm{mg} / \mathrm{m}^{2}$ & Plasma Ultrafiltrate & & HPLC-MS & $\begin{array}{l}0.0075 \\
\text { for } \mathrm{Pt}\end{array}$ & Yes & [115] \\
\hline Platinum & - & - & - & $\begin{array}{c}\text { Human plasma } \\
\text { ultrafiltrate }\end{array}$ & & ICP-MS & 0.0075 & $\mathrm{n} / \mathrm{a}$ & {$[115]$} \\
\hline Paclitaxel & $\begin{array}{l}\text { Antimitotic } \\
\text { agent }\end{array}$ & $\begin{array}{c}\text { Ovarian can- } \\
\text { cer }\end{array}$ & $\begin{array}{c}60 \mathrm{mg} / \mathrm{m}^{2} \\
\text { to } 1200 \\
\mathrm{mg} / \mathrm{m}^{2}\end{array}$ & Human plasma & $\begin{array}{c}6 \alpha \text {-hydroxy } \\
\text { paclitaxel } \\
\text { 3'- } p \text {-hydroxy } \\
\text { paclitaxel }\end{array}$ & HPLC-MS/MS & 0.1 & No & {$[137]$} \\
\hline Docetaxel & $\begin{array}{l}\text { Antimitotic } \\
\text { agent }\end{array}$ & \begin{tabular}{|c|} 
Ovarian can- \\
cer
\end{tabular} & $75 \mathrm{mg} / \mathrm{m}^{2}$ & Human plasma & & HPLC-MS/MS & 0.2 & Yes & [138] \\
\hline Topotecan & Topo-isomerase & $\begin{array}{l}\text { Neoplastic } \\
\text { meningitis }\end{array}$ & $\begin{array}{c}5-30 \\
\mathrm{mg} / \mathrm{m}^{2}\end{array}$ & Human plasma & & $\begin{array}{c}\text { HPLC- } \\
\text { Fluorescence }\end{array}$ & 0.05 & Yes & {$[162]$} \\
\hline
\end{tabular}

Abbreviations: HPLC-UV: High performance liquid chromatography coupled with ultraviolet detector; HPLC-PDA: High performance liquid chromatography coupled with photodiode array detector; HPLC-MS: High performance liquid chromatography coupled to mass spectrometry; HPLC-MS/MS: High performance liquid chromatography coupled to tandem mass spectrometry; HPLC-ICP-MS: High performance liquid chromatography coupled to inductively coupled plasma mass spectrometry; ICP-MS: Inductively coupled plasma mass spectrometry; LLOQ: Lower limit of quantitation; *: Method is sensitive enough when it allows the systemic detection of the locally administered anti-cancer agents; n/a: Not applicable (because no systemic pharmacokinetic studies have been performed or the compound was not measured); **: Pt concentrations are measured. 
Table 5. Selected Overview of Intrathecal Administration of Anti-Cancer Agents

\begin{tabular}{|c|c|c|c|c|c|c|c|c|c|}
\hline Drug & $\begin{array}{c}\text { Drug Classifi- } \\
\text { cation }\end{array}$ & Cancer Type & Dose & Matrix & $\begin{array}{c}\text { Metabolites/ } \\
\text { Degradation } \\
\text { Products }\end{array}$ & Method & $\begin{array}{c}\text { LLOQ } \\
(\mathrm{ng} / \mathrm{mL})\end{array}$ & $\begin{array}{l}\text { Is the } \\
\text { Method } \\
\text { Sensitive } \\
\text { Enough? }\end{array}$ & Ref. \\
\hline Methotrexate & Antimetabolites & $\begin{array}{c}\text { Acute leukaemia, } \\
\text { ostesarcoma, non-Hodgkin } \\
\text { lymphoma and breast } \\
\text { carcinoma, non-neoplastic } \\
\text { diseases }\end{array}$ & $12-15 \mathrm{mg}$ & $\begin{array}{l}\text { Human } \\
\text { plasma }\end{array}$ & $\begin{array}{l}\text { 7-hydroxy } \\
\text { methotrexate }\end{array}$ & $\begin{array}{l}\text { HPLC- } \\
\text { MS/MS }\end{array}$ & 0.1 & Yes & {$[71,73]$} \\
\hline Methotrexate & Antimetabolites & & & $\begin{array}{l}\text { Human } \\
\text { urine }\end{array}$ & $\begin{array}{l}\text { 7-hydroxy } \\
\text { methotrexate }\end{array}$ & $\begin{array}{l}\text { HPLC- } \\
\text { MS/MS }\end{array}$ & 0.4 & $\mathrm{n} / \mathrm{a}$ & {$[72,74]$} \\
\hline 7OH-MTX & Antimetabolites & & & $\begin{array}{l}\text { Human } \\
\text { plasma }\end{array}$ & - & $\begin{array}{l}\text { HPLC- } \\
\text { MS/MS }\end{array}$ & 0.3 & n.a & {$[71,73]$} \\
\hline 7OH-MTX & Antimetabolites & & & $\begin{array}{l}\text { Human } \\
\text { urine }\end{array}$ & - & $\begin{array}{l}\text { HPLC- } \\
\text { MS/MS }\end{array}$ & 50 & $\mathrm{n} / \mathrm{a}$ & {$[71,73]$} \\
\hline Cytarabine & Antimetabolites & Acute myeloid leukaemia & $15-70 \mathrm{mg}$ & $\begin{array}{l}\text { Human } \\
\text { plasma }\end{array}$ & - & $\begin{array}{l}\text { HPLC- } \\
\text { UV }\end{array}$ & 450 & No & [179] \\
\hline Cytarabine & Antimetabolites & Acute myeloid leukaemia & $15-70 \mathrm{mg}$ & $\begin{array}{l}\text { Mouse } \\
\text { plasma }\end{array}$ & - & $\begin{array}{l}\text { pSFC- } \\
\text { MS/MS }\end{array}$ & 50 & No & $\begin{array}{c}{[180,182,} \\
287]\end{array}$ \\
\hline Thiotepa & $\begin{array}{c}\text { DNA } \\
\text { alkylating agent }\end{array}$ & $\begin{array}{l}\text { Bladder tumors, ovarian } \\
\text { cancer, breast cancer, } \\
\text { lymphomas, bronchogenic } \\
\text { carcinoma, pleural, } \\
\text { pericardial }\end{array}$ & $5-11.5 \mathrm{mg} / \mathrm{m}^{2}$ & $\begin{array}{l}\text { Human } \\
\text { plasma }\end{array}$ & $\begin{array}{c}\text { Tepa } \\
\text { Thiotepa- } \\
\text { mercapturate }\end{array}$ & $\begin{array}{l}\text { HPLC- } \\
\text { MS/MS }\end{array}$ & 5 & $\mathrm{n} / \mathrm{a}$ & {$[96,97]$} \\
\hline Tepa & $\begin{array}{c}\text { DNA } \\
\text { alkylating agent }\end{array}$ & $\begin{array}{l}\text { Bladder tumors, ovarian } \\
\text { cancer, breast cancer, } \\
\text { lymphomas, bronchogenic } \\
\text { carcinoma, pleural, } \\
\text { pericardial }\end{array}$ & - & $\begin{array}{l}\text { Human } \\
\text { plasma }\end{array}$ & - & $\begin{array}{l}\text { HPLC- } \\
\text { MS/MS }\end{array}$ & 5 & $\mathrm{n} / \mathrm{a}$ & [96] \\
\hline Busulfan & $\begin{array}{c}\text { DNA } \\
\text { alkylating agent }\end{array}$ & Neoplastic meningitis & $5-17 \mathrm{mg}$ & $\begin{array}{l}\text { Human } \\
\text { plasma }\end{array}$ & & $\begin{array}{l}\text { HPLC- } \\
\text { MS/MS }\end{array}$ & 5 & Yes & {$[191,193]$} \\
\hline Mafosfamide & $\begin{array}{c}\text { DNA } \\
\text { alkylating agent }\end{array}$ & CNS tumors & $\begin{array}{l}\text { from } 1 \text { to } \\
6.5 \mathrm{mg}\end{array}$ & $\begin{array}{l}\text { Human } \\
\text { plasma }\end{array}$ & $\begin{array}{l}\text { 4-hydroxycyclo- } \\
\text { phosphamide }\end{array}$ & $\begin{array}{l}\text { HPLC- } \\
\text { MS/MS }\end{array}$ & 200 & $\mathrm{n} / \mathrm{a}$ & {$[96,204]$} \\
\hline $\begin{array}{c}\text { 4-hydroxy } \\
\text { cyclophosphamide }\end{array}$ & $\begin{array}{c}\text { DNA } \\
\text { alkylating agent }\end{array}$ & CNS tumors & $\begin{array}{l}\text { from } 1 \text { to } \\
6.5 \mathrm{mg}\end{array}$ & $\begin{array}{l}\text { Human } \\
\text { plasma }\end{array}$ & - & $\begin{array}{l}\text { HPLC- } \\
\text { MS/MS }\end{array}$ & 50 & n.a & {$[96,204]$} \\
\hline Topotecan & $\begin{array}{l}\text { Topo- } \\
\text { isomerase }\end{array}$ & Neoplastic meningitis & $0.4 \mathrm{mg}$ & $\begin{array}{l}\text { Human } \\
\text { plasma }\end{array}$ & & $\begin{array}{l}\text { HPLC- } \\
\text { Fluores- } \\
\text { cence }\end{array}$ & 0.05 & $\mathrm{n} / \mathrm{a}$ & {$[162]$} \\
\hline
\end{tabular}

Abbreviations: HPLC-UV: High performance liquid chromatography coupled with ultraviolet detector; HPLC-MS/MS: High performance liquid chromatography coupled to tandem mass spectrometry; pSFC-MS/MS: Packed-column supercritical fluid chromatography coupled to tandem mass spectrometry; LLOQ: Lower limit of quantitation; *: Method is sensitive enough when it allows the systemic detection of the locally administered anti-cancer agents; n/a: Not applicable (because no systemic pharmacokinetic studies have been performed or the compound was not measured).

breast cancer [83]. It exerts a cytotoxic effect through the formation of inter- or intrastrand DNA cross-links or DNAprotein cross-links via the two chlorethyl groups of the molecule (Fig. 12). Unlike other mustards, melphalan does not require metabolic activation in order to become cytotoxic; it dechlorinates spontaneously and forms a highly reactive intermediate aziridinium ion, which immediately reacts with DNA forming melphalan adducts (Fig. 12) [84]. Melphalan undergoes rapid spontaneous hydrolysis in aqueous solution at room temperature and yields two hydrolysis products, monohydroxy-melphalan $(\mathrm{MOH})$ and dihydroxymelphalan $(\mathrm{DOH})$; neither of these degradation products have cytotoxic activity $[85,86]$. Various analytical assays have been published to determine melphalan in human plasma $[83,85,87-90]$. However, most of the methods involve labor intensive sample pretreatment, long chroma- tographic run times and considerable volumes of the sample and reagents. The most sensitive assay for melphalan analysis in human plasma is presented by Davies et al. utilizing a HPLC-MS/MS method with the LLOQ of $2 \mathrm{ng} / \mathrm{mL}$ [91]. In this assay, automated solid phase extraction is carried out with $\mathrm{C} 18$ sorbent packed in a 96 well format microlitre plate using a robotic sample processor. The extracts are analyzed by reversed phase liquid chromatography using pneumatically and thermally assisted electrospray ionization with selected ion reaction monitoring. Melphalan and its stable isotopically labeled internal standard were chromatographed in less than 2 minutes since no chromatographic separation between the analyte and the internal standard was needed due to the mass selective nature of the mass spectrometry. Using the sample volumes of $200 \mu \mathrm{L}$ the LLOQ was 2 $\mathrm{ng} / \mathrm{mL}[91]$. 
<smiles>CN(Cc1cnc2nc(N)nc(N)c2n1)c1ccc(C(=O)NC(CCC(=O)O)C(=O)O)cc1</smiles>

Methotrexate<smiles>CN(Cc1nc2c(N)nc(N)nc2nc1O)c1ccc(C(=O)NC(CCC(=O)O)C(=O)O)cc1</smiles>

\section{7-hydroxy Methotrexate}

Fig. (11). Structures of methotrexate and its metabolite 7hydroxymethotrexate.

Several studies have been performed with i.p. administered melphalan alone or with other cytotoxic drugs, such as cisplatin. The administered dose of melphalan varied from $16 \mathrm{mg} / \mathrm{kg}$ to $30 \mathrm{mg} / \mathrm{kg}[92,93]$. Recently, Sugarbaker et al . described the study with i.p. melphalan to assess the pharmacokinetics and to evaluate the potential clinical advantages of heated intraoperative i.p. melphalan as adjuvant therapy for patients with residual disease after cytoreductive surgery for peritoneal surface malignancies [94]. The dose of $70 \mathrm{mg} / \mathrm{m}^{2}$ was given to the patients and the lowest determined concentration of melphalan in plasma was $100 \mathrm{ng} / \mathrm{mL}$ (the LLOQ of the used method was not mentioned). Prior to and very 15 min during the 90 min of perfusion, blood samples were obtained for the analysis. Consequently, the method developed by Davies et al. with a LLOQ of $2 \mathrm{ng} / \mathrm{mL}$ is far sufficient to measure the systemic exposure to melphalan after i.p. administration.

\subsubsection{Thiotepa}

Thiotepa is a DNA alkylating agent. It is extensively metabolized by the liver to tepa, which is also cytotoxic. Van Maanen et al. identified in urine a new metabolite of thiotepa with alkylating capacity, thiotepa-mercapturate [95]. De Jonge et al. has developed and validated a HPLC-MS/MS method for the quantitation of thiotepa and tepa with a LLOQ of $5 \mathrm{ng} / \mathrm{mL}$ [96]. Sample pretreatment consisted of protein precipitation with a mixture of methanol and acetonitrile using only $100 \mu \mathrm{L}$ human plasma. Chromatographic separation was achieved on Zorbax Extend C18 column and the detection was performed by means of triple quadrupole mass spectrometer, which was operating in the positive ion mode and multiple reaction monitoring (MRM) was used for drug quantification. [96,97]. Interestingly, while most other assays employ an acidic eluent, such as acetic acid and formic acid, the successful use of an alkaline eluent containing ammonium hydroxide combined with LC-MS/MS in the positive ionization mode is demonstrated here. Positive ionization in the electrospray ion source in the presence of ammonium hydroxide most likely results from ion-molecule reactions (IMR) between the analyte molecule (M) and ammonium ions or collision-induced dissociation (CID) of ammonium adducts of the analyte under influence of the electrospray voltage, as proposed by Zhou at al [98]:

IMR: $\quad \mathrm{NH}_{4}^{+}(\mathrm{g})+\mathrm{M} \quad \rightarrow \mathrm{NH}_{3}(\mathrm{~g})+\mathrm{MH}^{+}$

or

CID: $\quad\left(\mathrm{NH}_{3}-\mathrm{H}^{+}-\mathrm{M}\right)(\mathrm{g}) \rightarrow \mathrm{NH}_{3}(\mathrm{~g})+\mathrm{MH}^{+}$

For either reaction to be thermodynamically favoured requires that thiotepa and tepa is a stronger gas-phase base than $\mathrm{NH}_{3}$. This approach has demonstrated to be very useful for the quantitative analysis of basic anti-cancer agents, such

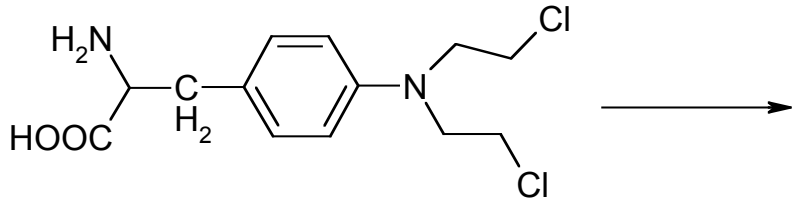

Melphalan

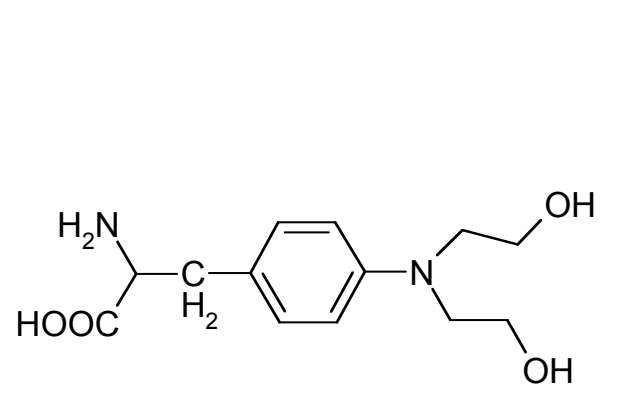

Dihydroxymelphalan

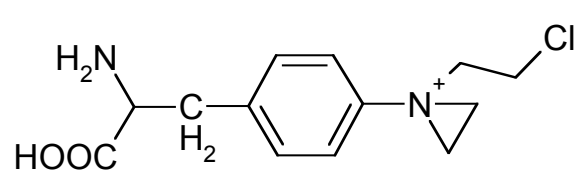

Reactive intermediate

$\downarrow \begin{aligned} & \text { Hydrolysis } \\ & \mathrm{OH}-\end{aligned}$

Hydrolysis

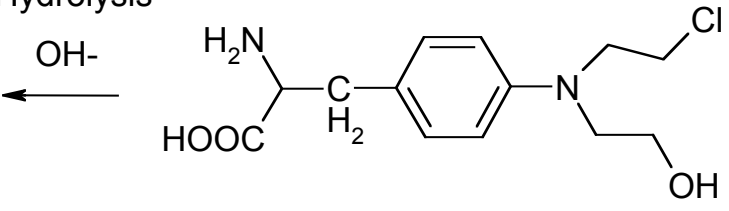

Monohydroxymelphalan

Fig. (12). Molecular structures of Melphalan, its reactive intermediate and its hydrolysis products monohydroxymelphalan (MOH) and dihydroxymelphalan $(\mathrm{DOH})$. 
as ABT-518, Kahalalide F and paclitaxel and its metabolites [99-102].

Thiotepa at doses of $0.8 \mathrm{mg} / \mathrm{kg}$ has been administered i.p. to prevent recurrence of ascites in ovarian cancer [103-106]. Treatment was well tolerated and no acute inflammatory reactions were seen. After experimental administration of ${ }^{32}$ P-radiolabeled thiotepa, the drug was slowly reabsorbed from peritoneal fluid. It was observed, that the radioactivity measured in the peritoneal fluid was 10-100-fold higher after i.p. administration compared to i.v., concluding that thiotepa might prove to be a useful component of i.p. chemotherapy [103]. In studies, thiotepa was given at doses varying from $30 \mathrm{mg} / \mathrm{m}^{2}$ to $80 \mathrm{mg} / \mathrm{m}^{2}$ as i.p. instillation [103,107]. In the Phase I study performed by Lewis et al., 15 patients received a total of 50 courses with thiotepa ranging from $30 \mathrm{mg} / \mathrm{m}^{2}$ to $80 \mathrm{mg} / \mathrm{m}^{2}$ [108]. The dose limiting toxicity was myelosuppression, which occurred at $80 \mathrm{mg} / \mathrm{m}^{2}$. Peritoneal fluid concentrations declined rapidly in a first-order fashion [108]. Approximately $93 \%$ of the drug was absorbed during a $4 \mathrm{~h}$ dwell time. The detected plasma concentrations were approximately $25 \mathrm{ng} / \mathrm{mL}$, and consequently detectable by the sensitive method for the determination of thiotepa in human plasma with a LLOQ of $5 \mathrm{ng} / \mathrm{mL}$ as described by de Jonge et al. [96].

\subsection{Platinum Anti-Cancer Drugs}

\subsubsection{Cisplatin}

Cisplatin is a platinum based drug that is widely used in the clinical treatment of testicular, ovarian, lung, head and neck cancers (Fig. 13) [109-112]. Indirectly, cisplatin reacts with DNA to form cross-links leading to inhibition of DNA replication, cell division and induce apoptosis [112]. After intraveneous infusion, cisplatin and its reactive metabolites become rapidly portioned into plasma protein-bound platinum $(\mathrm{Pt})$, free plasma $\mathrm{Pt}$, tissue $\mathrm{Pt}, \mathrm{Pt}$ in peripheral blood mononuclear cells and erythrocyte-sequestered Pt [113]. Currently available methods to determine cisplatin employ inductively coupled plasma mass spectrometry (ICP-MS) and have LLOQ of $2 \mathrm{ng} / \mathrm{mL}$ in human plasma ultrafiltrate $[109,114]$. However, once cisplatin will enter into the systemic circulation, it will form a variety of hydrolyzed intermediates. These intermediates will be partitioned into plasma protein-bound metal, free plasma metal, tissue metal, white blood cell metal, and erythrocyte-sequestered metal. Therefore, it is technically very difficult to measure cisplatin intact, and usually the total platinum content is measured to investigate the pharmacokinetics of the platinum compound. An ultrasensitive ICP-MS method for the quantification of platinum in plasma ultrafiltrate with the LLOQ of $7.5 \mathrm{pg} / \mathrm{mL}$ has recently been presented by Brouwers et al. [115]. Since the first application of ICP-MS for oncology research in
1990, ICP-MS has become an accepted and very important technique for the analysis of Pt anti-cancer agents. Atomic absorption spectrometry (AAS) is also an useful technique to determine Pt and other metals, but ICP-MS proved to be a far more sensitive instrument, however, it is also more costly. ICP-MS has several advantages over other methods, including a wide linear range, high sensitivity, potential for isotope determinations and multi-element capability [116]. It is also a less labor-intensive method, because the signal intensities are dependent only on the chemical structure of the analyte incorporating the metal and hence the method does not need standards of analyte/metabolite/adduct [116]. For the determination of platinum originating from cisplatin, Brouwers et al. used dilution of samples 100-fold with $1 \%$ nitric acid as a means of sample pretreatment. The detection was performed by ICP-MS. This method was validated according to the FDA guidelines, as far as applicable for ICPMS [115].

Cisplatin is used in the treatment of the ovarian cancer, however because of its toxicity, including nephro-, oto-, and neurotoxicity, other platinum anti-cancer agents, such as carboplatin are employed $[111,117]$. In addition, there are three large randomized phase III studies comparing i.p. vs i.v. cisplatin-based chemotherapy [118-120]. Although all trials have shown survival benefit of i.p. chemotherapy, this approach has not yet been accepted as a standard treatment for selected ovarian cancer patients. I.p. cisplatin is given at a dose of $100 \mathrm{mg} / \mathrm{m}^{2}$.

Recently, Royer et al. investigated the serum and i.p. pharmacokinetics of cisplatin within intraoperative i.p. chemotherapy [121]. Serum and i.p. measurements of total and unltrafilterable platinum were quantified to determine pharmacokinetic parameters in 11 consecutive patients who received a $2 \mathrm{~h}$ intraoperative i.p. chemotherapy with $50 \mathrm{mg} / \mathrm{m}^{2}$ cisplatin. I.p. platinum concentration decreased rapidly; the mean lowest systemic concentration of Pt was approximately $50 \mathrm{ng} / \mathrm{mL}$ after $25 \mathrm{~h}$, concluding that the method developed by Brouwers et al. with a LLOQ of $7.5 \mathrm{pg} / \mathrm{mL}$ would be very sufficient to measure the traces of the systemical present $\mathrm{Pt}$ after i.p. cisplatin.

\subsubsection{Carboplatin}

Carboplatin (Fig. 13) is less toxic than cisplatin and therefore, it was reasonable to test its role in the i.p. treatment of ovarian cancer. However, despite the fact that i.v. administration of carboplatin has now become a standard platinum agent in the treatment of the epithelial cancer, i.p. administration of carboplatin has been ignored for years [118]. There is one available HPLC-MS/MS method to determine intact carboplatin in rat plasma ultrafiltrate with a LLOQ of $70 \mathrm{ng} / \mathrm{mL}$, presented by Gou et al. [122]. Car-

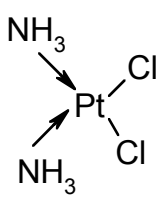

Cisplatin

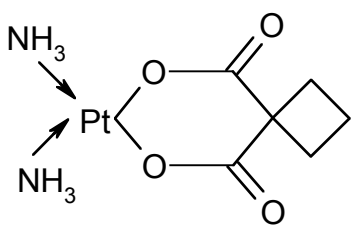

Carboplatin

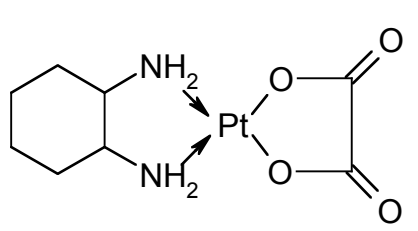

Oxaliplatin

Fig. (13). Structural formula of cisplatin, carboplatin and oxaliplatin. 
boplatin was extracted from only $50 \mu \mathrm{L}$ rat plasma ultrafiltrate using solid phase extraction cartridges, with $10 \mu \mathrm{L}$ aliquots were injected onto the reversed phase HPLC system and analyzed by positive electrospray MS [122]. The full scan spectrum was dominated by three major isotopes of platinum at $m / z$ of $370.3,371.3$ and 372.3 with similar relative intensities. In the blanks, trace peaks at $\mathrm{m} / \mathrm{z}$ of 371.3 and 372.3 were observed with a signal intensity of about two-to three-fold higher than baseline. Therefore, the $m / z$ of 370.3 was chosen for detecting carboplatin in biological matrices [122]. Another method by Brouwers et al., as described in the previous section, allowed determination of the Pt resulting from carboplatin, cisplatin and oxaliplatin in human plasma ultrafiltrate at a LLOQ of $7.5 \mathrm{pg} / \mathrm{mL}$ [115]. Although this method is more sensitive for Pt, some researchers prefer not to atomize the compound but to detect the intact drug as this may yield more adequate pharmacokinetic profiles [122].

Recently, several studies have been executed investigating i.p. carboplatin. It was found that the administered dose of carboplatin had to be almost 6 times higher than that of cisplatin to achieve comparable tissue concentration for the same effect. Therefore, $400 \mathrm{mg} / \mathrm{m}^{2}$ of carboplatin has been used with sufficient effect [118,123].

Miyagi et al. investigated whether i.p. carboplatin infusion may be indeed a pharmacologically more reasonable route than i.v. administration as a systemic therapy [70]. The lowest systemic Pt concentration after i.p. administration of carboplatin was approximately $80 \mathrm{ng} / \mathrm{mL}$ after $25 \mathrm{~h}$. Thus the assay designed by Brouwers et al. will be very applicable to measure the systemic concentrations of Pt after i.p. administration of carboplatin.

\subsubsection{Oxaliplatin}

Oxaliplatin is anti-cancer agent (Fig. 13), which is currently used on a large scale to treat colorectal cancers. An ICP-MS method for the determination of total Pt levels has been described in human plasma ultrafiltrate with an LLOQ of $7.5 \mathrm{pg} / \mathrm{mL}$ [115]. Peritoneal carcinomatosis (PC) is one of the most common causes of incurability of intra-abdominal cancers. Surgery or chemotherapy alone is not able to cure this disease. However, when surgery was combined with hyperthermic i.p. chemotherapy (HIPEC), promising results were achieved [124]. Oxaliplatin does not cause renal or hepatic toxicity and is used as chemotherapeutic agent for HIPEC therapy. In the prospective phase II study described by Elias et al., a total of 106 patients were included and after complete resection of the PC, HIPEC was executed with oxaliplatin $\left(360 \mathrm{mg} / \mathrm{m}^{2}\right)$ combined with irinotecan $(360$ $\mathrm{mg} / \mathrm{m}^{2}$ ) in $2 \mathrm{~L} / \mathrm{m}^{2}$ of $5 \%$ dextrose, over 30 minutes at a real i.p. temperature of $43^{\circ} \mathrm{C}$ [124]. Unfortunately, no human plasma measurements were performed to investigate the systemic leakage of oxaliplatin. However, recently, another study by Gesson-Paute et al. described the pharmacokinetics of oxaliplatin in pigs after i.p. administration at a dose of 460 $\mathrm{mg} / \mathrm{m}^{2}$ [125]. Platinum levels were measured using AAS analysis with a LLOQ of $20.9 \mathrm{ng} / \mathrm{mL}$ in plasma ultrafiltrate. The lowest concentration measured in this study is approximately $300 \mathrm{ng} / \mathrm{mL}$. Thus, the published ICP-MS methods will be of value to determine Pt in human plasma ultrafiltrate after i.p. oxaliplatin administration [115].

\subsection{Antimitotic Agents}

Antimitotic drugs inhibit cell division by binding to tubulin. This class of compounds predominantly consists of vinca alkaloids, such as vinorelbine, vinblastine, vincristine, and the taxanes, paclitaxel and docetaxel.

\subsubsection{Paclitaxel}

Cytotoxic activity of paclitaxel is derived from its ability to increase the assembly and stability of microtubules in dividing cells, thereby blocking the cell cycle. Paclitaxel has significant clinical activity against a broad range of tumor types including breast, lung, head and neck, bladder, and platinum-refractory ovarian carcinoma [126,127]. Paclitaxel is metabolized in the human liver by cytochromes P450 (CYP) 2C8 and 3A4 [128-130]. Previous studies have shown that the major hepatic metabolite is $6 \alpha$-hydroxy paclitaxel (6OHP) with an OH-group at $\mathrm{C} 6$ at the taxane ring [131] and a minor metabolite is $3^{\prime}$ - $p$-hydroxy paclitaxel (3OHP) with an $\mathrm{OH}$-group at the $\mathrm{C} 3$ ' of the phenyl in the side chain at C13 [132]. Both metabolites exhibit the excessive microtubule stabilizing properties of the parent compound [129]. Furtermore, these metabolites can be oxidized to $6 \alpha-, 3^{\prime}-p$ dihydroxy paclitaxel (3,6OHP) [133] (Fig. 14).

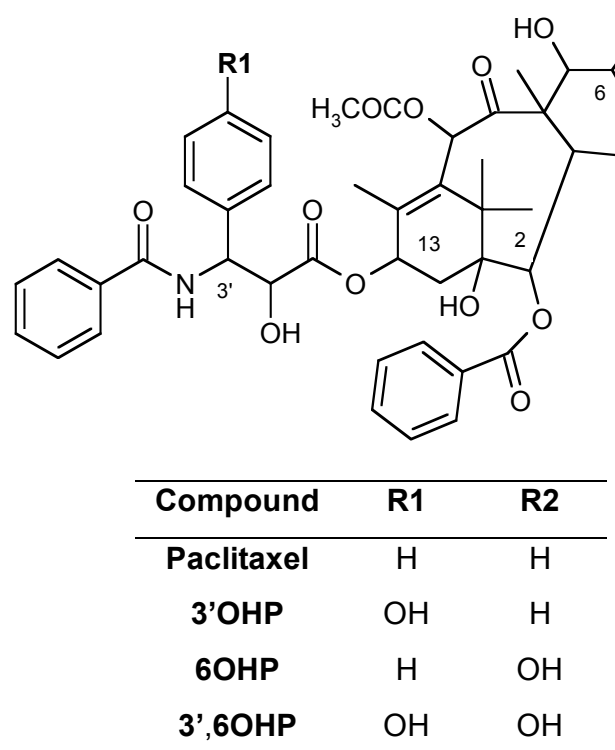

Fig. (14). Chemical structure of paclitaxel, $3^{\prime}-p$-hydroxy paclitaxel and 6- $\alpha$-hydroxy paclitaxel and 6- $\alpha-, 3^{\prime}-p$-dihydroxy paclitaxel.

Many assays for the quantitative determination of paclitaxel have been described using HPLC-UV and HPLCMS/MS [99,102,134-144]. Most of the HPLC-UV methods utilize a significant amount of sample, e.g. $1000 \mu \mathrm{L}$ and the lowest LLOQ is approximately $5 \mathrm{ng} / \mathrm{mL}$. The use of the HPLC-MS for the determination of paclitaxel resulted in a more than $50 \%$ reduction of the chromatographic run time and a 25 -fold increase in sensitivity. Thus far, the most sensitive HPLC-MS/MS assay utilizes $400 \mu \mathrm{L}$ of sample aliquots, a simple liquid-liquid extraction with tertbutylmethylether and detection of polar 6OHP and 3OHP metabolites with a LLOQ of $0.1 \mathrm{ng} / \mathrm{mL}$ [137]. This assay by Alexander et al. describes the use of ${ }^{13} \mathrm{C}_{6}$-paclitaxel as an internal standard, which yielded excellent results on accuracy and precision. There are several other assays developed with a LLOQ of $0.25 \mathrm{ng} / \mathrm{mL}$ and $0.5 \mathrm{ng} / \mathrm{mL}$ for paclitaxel 
and its metabolites utilizing less plasma sample aliquots, e.g. $200 \mu \mathrm{L}[99,102]$.

Several clinical trials demonstrated the activity of i.p. paclitaxel against advanced ovarian cancer [145,146-153]. The results from 6 randomized trials showed that i.p. therapy yielded approximately $21 \%$ decrease in the risk of death and 12-month longer overall survival time. The first clinical trials were conducted with the Cremophor EL: ethanol (Taxol ${ }^{\circledR}$, referred as Cremophor) formulation. In humans, Cremophor is slowly cleared from the peritoneal cavity. Because the entrapment of paclitaxel in Cremophor micelles reduces the free drug fraction available to tumors, it is still uncertain whether a longer residence of the Cremophor formulation translates to greater antitumor activity [147]. Recently, Tsai et al. investigated the effects of carrier on the disposition and efficacy of i.p. paclitaxel. Three paclitaxel formulations with different particle size and release rates have been tested: Cremophor formulation, Cremophor-free paclitaxel-loaded gelatin nanoparticles and Cremophor-free paclitaxel-loaded polymeric microparticles [147]. Several preclinical and phase I studies have been performed with i.p. administered paclitaxel. One of the latest studies with i.p. sustained-release paclitaxel microspheres in recurrent ovarian cancer has been executed by Armstrong et al. [146]. The dose varied from $60 \mathrm{mg} / \mathrm{m}^{2}$ to $1200 \mathrm{mg} / \mathrm{m}^{2}$. Even the highest dose was well tolerated, and low but persistent detection of plasma levels indicated that paclitaxel continued to be released for at least 8 weeks after paclitaxel microparticles treatment. Armstrong et al. could not detect any systemic levels of paclitaxel after the lowest dose of $60 \mathrm{mg} / \mathrm{m}^{2}$ treatment, using an ultra sensitive analytical method with a LLOQ of $0.1 \mathrm{ng} / \mathrm{mL}$.

\subsubsection{Docetaxel}

Docetaxel (Taxotere $\AA$ ) is a semisynthetic and a more potent analogue of paclitaxel. Although, paclitaxel is currently the most commonly used taxane, docetaxel seems to be as effective in systemic chemotherapy for primary or recurrent advanced epithelial ovarian cancer [154-157]. Several HPLC-MS/MS methods have been developed for the quantitation of docetaxel in human plasma [135,138,158]. Wang et al. reported a simple and sensitive HPLC-MS/MS method for the determination of docetaxel in human plasma by means of a simple liquid-liquid extraction with terbutylmethyl ether utilizing only $50 \mu \mathrm{L}$ sample aliquots and yielding a LLOQ of $5 \mathrm{ng} / \mathrm{mL}$ [158]. The run time of this assay was 3 minutes and positive mode of ionization was used. Although, the method described by Parise et al. yields a lower LLOQ of only $0.2 \mathrm{ng} / \mathrm{mL}$, it requires $1000 \mu \mathrm{L}$ sample aliquots and a time consuming solid phase extraction [138].

Recently, Yokogawa et al. studied the disposition kinetics of docetaxel after i.p. administration in rats [150]. Rats received $40 \mathrm{mg} / \mathrm{kg}$ of docetaxel and the lowest detectable concentration in plasma was approximately $80 \mathrm{ng} / \mathrm{mL}$, measured by the method described by Loos et al., with a LLQQ of $50 \mathrm{ng} / \mathrm{mL}$ which proved to be adequate for this application. Another pharmacokinetic study of docetaxel in intraoperative hyperthermic i.p. therapy for ovarian cancer was executed by de Bree et al. [154]. The purpose of this study was to evaluate the pharmacokinetics and toxicity of docetaxel in continuous hyperthermic perfusion peritoneal chemotherapy after cytoreductive surgery for peritoneal in- volvement of gynecological malignancies, mainly ovarian cancer. 18 patients received $75 \mathrm{mg} / \mathrm{m}^{2}$ docetaxel at $41-43^{0} \mathrm{C}$. The use of docetaxel resulted in high i.p. versus systemic ratio, however the lowest $\mathrm{Cmax}$ in plasma was detected at 75 $\mathrm{ng} / \mathrm{mL}$, measured by the method developed by Rosing et al. [135] with a LLOQ of $10 \mathrm{ng} / \mathrm{mL}$. Consequently, the LLOQ's of this and the method developed by Parise et al. [138] are sufficient to determine the systemic leakage of i.p. paclitaxel.

\subsection{Topo-Isomerase Inhibitors}

The nuclear enzymes topo-isomerase I and II transiently break a single strand or double strand of DNA, respectively, during DNA replication, and thereby reducing torsional strain. Inhibitors of these enzymes damage DNA, leading to cell death. This family of anti-cancer drugs has grown rapidly in recent years.

\subsubsection{Topotecan}

Topotecan is a semisynthetic and water soluble analogue of camptothecin, which showed a potent inhibition of the topoisomerase I enzyme, interfering with the replication and transcription process in tumor cells. This compound has anticancer activity against a variety of solid tumors. Topotecan is known to undergo a $\mathrm{pH}$-dependant, reversible hydrolytic dissociation of its lactone moiety into the hydroxyl carboxylate form $[159,160]$. Demethylation to form N-desmethyltopotecan has been identified as a metabolic pathway for topotecan in humans (Fig. 15) [161]. This metabolite was found in plasma and urine of patients treated with topotecan. In vitro and in vivo pharmacological studies suggest that antitumor activity of the lactone form is higher than that of the carboxylate form. In the last years, several HPLC methods using fluorescence detection were developed [159-165]. Topotecan is a basic, highly polar compound in its protonated form. Most of the methods measure the lactone and carboxylate forms separately, but a few methods exist where both forms are measured simultaneously in one assay, chromatographically separated. Beijnen et al. described the first assay of topotecan with a LLOQ of $1 \mathrm{ng} / \mathrm{ml}$ utilizing only $100 \mu \mathrm{L}$ human plasma [160]. Later, Rosing et al. presented an ultra sensitive assay for the lactone and carboxylate forms with a LLOQ of $0.05 \mathrm{ng} / \mathrm{mL}$ using $100 \mu \mathrm{L}$ human plasma aliquots, but these forms were not analyzed simultaneously $[161,164]$. Recently, Vali et al. documented a simple and rapid HPLC-fluorescence method for the simultaneous separation of lactone and carboxylate forms of topotecan in human plasma with a LLOQ of $0.05 \mathrm{ng} / \mathrm{mL}$ for both forms of topotecan [162]. However, compared to $100 \mu \mathrm{L}$ human plasma aliquots used by Rosing et al, this method requires $400 \mu \mathrm{L}$ human plasma. Vali et al. used reversed-phase HPLC with $\mathrm{C}_{18}$ column and a mobile phase consisting of ammonium acetate buffer, acetonitrile, triethylamine (TEA) and tetrabutyl ammonium hydrogen sulphate (TBAHS), which enabled the simultaneous separation of carboxylate and lactone species of topotecan with less than 10 minutes. The use of TBAHS had a large impact on the peak sharpness and decrease in the retention of the lactone form of topotecan, moreover, TBAHS had no effect on the retention of the carboxylate form, leading to good resolution of the peaks and short run time. TEA was incorporated in the assay to minimize the peak tailing and to improve precision of the method an internal standard, tetracycline $\mathrm{HCl}$, was used. 
<smiles>CCC1(O)C(=O)OCc2c1cc1n(c2=O)Cc2cc3c(CN(C)C)c(O)ccc3nc2-1</smiles>

Topotecan<smiles>CCC(O)(C(=O)[O-])c1cc2n(c(=O)c1CO)Cc1cc3c(CN(C)C)c(O)ccc3nc1-2</smiles>

Carboxylate form<smiles>CCC1(O)C(=O)OCc2c1cc1n(c2=O)Cc2cc3c(CNC)c(O)ccc3nc2-1</smiles>

$\mathrm{N}$-desmethyltopotecan<smiles>CCC(O)(C(=O)[O-])c1cc2n(c(=O)c1CO)Cc1cc3c(CNC)c(O)ccc3nc1-2</smiles>

Carboxylate form

Fig. (15). Chemical structures of topotecan and N-desmethyltopotecan and their degradation products, undergoing pH-dependant hydrolysis.

The pharmacokinetics of topotecan suggests that a substantional pharmacokinetic advantage might be obtained following i.p. injection. The peritoneal/plasma concentration ratio at steady-state is proportional to the peritoneal and plasma clearances of the drug [166-168]. Three phase I pharmacokinetic studies have been performed. Plaxe et al. administered the dose of $3 \mathrm{mg} / \mathrm{m}^{2}-4 \mathrm{mg} / \mathrm{m}^{2}$ to seventeen patients in a total of 43 cycles at 21-day interval. The acute dose-limiting toxicity was neutropenia. Plasma pharmacokinetic behavior was best described by first-order kinetics with a half-life of 3.9 hours. The concentration in plasma were measured to be approximately $4 \mathrm{ng} / \mathrm{mL} 36$ hours following the start of i.p. instillation using the method described by Rosing et al. with a LLOQ of $0.05 \mathrm{ng} / \mathrm{mL}$ [166]. Hofstra et $a l$. performed a phase I study to evaluate the feasibility and pharmacology of i.p. topotecan [168]. Fifteen patients with recurrent ovarian cancer were treated with escalating i.p. topotecan doses $\left(5-30 \mathrm{mg} / \mathrm{m}^{2}\right)$ for pharmacokinetic analysis. The lowest detectable concentration of topotecan in plasma was approximately $3 \mathrm{ng} / \mathrm{mL}$, measured by an assay with a LLOQ of $0.05 \mathrm{ng} / \mathrm{mL}$ [164]. Recently executed phase I study by Bos et al. aimed to determine the maximum tolerated dose (MTD) of i.p. topotecan [167]. Woman with primary ovarian cancer received 6 cycles with escalating topotecan doses of $10-25 \mathrm{mg} / \mathrm{m}^{2}$. In this setting the MTD of i.p. topotecan was $20 \mathrm{mg} / \mathrm{m}^{2}$. The lowest detectable concentrations were measured after 20 hours and were 3-4 $\mathrm{ng} / \mathrm{mL}$. Consequently, the LLOQ's of several methods are sufficient to determine the systemic leakage of i.p. administered topotecan.

\section{INTRATHECAL ADMINISTERED ANTI-CANCER AGENTS}

For the inthrathecal (i.t.) route, a needle is inserted between two vertebrae in the lower spine and into the space around the spinal cord. This way the drug is injected into the spinal canal. Usually, a small amount of local anesthetic is used to numb the injection site. This route is used when a drug is needed to produce rapid and local effects on the brain, spinal cord or the layers of tissue covering them (meninges) (Table 6).

\subsection{Anti-Metabolites}

\subsubsection{Methotrexate}

Although the usual route of administration of MTX is oral or i.v., this antimetabolite is also administered i.t. for the prophylactic treatment of the central nervous system sanctuary sites in leukemia, lymphoma and in the treatment of meningeal carcinomas. For i.t. treatment, the usual dose of MTX is 12-15 mg [169-172]. There have been several studies executed with i.t. MTX. The kinetics of MTX disappearance from the CSF after i.t. injection was studied extensively by Bode and others [173-178]. Thyss et al. investigated the systemic effect of i.t. MTX during initial phase of treatment of childhood acute lymphoblastic leukemia. The results demonstrated a therapeutic systemic effect of low doses of MTX [174,177]. Moreover, as described by Thyss et al. and Ettinger et al. plasma levels of approximately 50 to 300 $\mathrm{ng} / \mathrm{mL}$ occur 3 to 12 hours after i.t. injection, and then decrease in a bi-exponential manner with a terminal half-life of 
Table 6. Selected Overview of Intravesical Administration of Anti-Cancer Agents

\begin{tabular}{|c|c|c|c|c|c|c|c|c|c|}
\hline Mitomycin C & $\begin{array}{l}\text { DNA alkylat- } \\
\text { ing agent }\end{array}$ & $\begin{array}{c}\text { Bladder } \\
\text { cancers }\end{array}$ & $2-60 \mathrm{mg}$ & $\begin{array}{l}\text { (i) Human plasma } \\
\text { (ii) Human urine } \\
\text { (iii) Human tumor } \\
\text { (iv) Human humor } \\
\text { (v) Human ocular } \\
\text { tissue }\end{array}$ & $\begin{array}{l}\text { 2,7-diaminomitosene } \\
\text { 1,2-cis-hydroxy- } \\
\text { 2,7-diaminotoserone }\end{array}$ & $\begin{array}{l}\text { (i) HPLC-UV } \\
\text { (ii) HPLC-UV } \\
\text { (iii) HPLC- } \\
\text { PDA } \\
\text { (iv) HPLC-UV } \\
\text { (v) HPLC- } \\
\text { PDA }\end{array}$ & $\begin{array}{l}\text { (i) } 0.5 \\
\text { (ii) } 1 \\
\text { (iii) } 20 \\
\text { ng/g } \\
\text { (iv) } 6.25 \\
\text { (v) } 1\end{array}$ & Yes & [49-59] \\
\hline \begin{tabular}{|c|}
$2,7-$ \\
diaminomitosene \\
1,2-cis-hydroxy- \\
2,7-diaminotoserone
\end{tabular} & - & - & - & Human tumor & - & HPLC-UV & 100 & $\mathrm{n} / \mathrm{a}$ & [49] \\
\hline EO9 & $\begin{array}{l}\text { DNA alkylat- } \\
\text { ing agent }\end{array}$ & $\begin{array}{c}\text { Bladder } \\
\text { cancer }\end{array}$ & $4 \mathrm{mg}$ & $\begin{array}{l}\text { (i) Human plasma } \\
\text { (ii) Human urine }\end{array}$ & EO5a, EO9-Cl & $\begin{array}{l}\text { (i) HPLC- } \\
\text { MS/MS } \\
\text { (ii) HPLC- } \\
\text { MS/MS }\end{array}$ & $\begin{array}{l}\text { (i) } 0.5 \\
\text { (ii) } 100\end{array}$ & No & {$\left[\begin{array}{c}{[234,237} \\
288]\end{array}\right.$} \\
\hline $\mathrm{EO} 9-\mathrm{Cl}$ & - & - & - & (i) Human urine & - & $\begin{array}{l}\text { (i) HPLC- } \\
\text { MS/MS }\end{array}$ & (i) 100 & & $\begin{array}{c}{[234,237,} \\
288]\end{array}$ \\
\hline Thiotepa & $\begin{array}{l}\text { DNA alkyla- } \\
\text { ting agent }\end{array}$ & $\begin{array}{c}\text { Bladder } \\
\text { tumors }\end{array}$ & $30-60 \mathrm{mg}$ & Human plasma & $\begin{array}{c}\text { Tepa } \\
\text { Thiotepa-mercapturate }\end{array}$ & HPLC-MS/MS & 5 & Yes & {$[96,97]$} \\
\hline Tepa & $\begin{array}{l}\text { DNA alkyla- } \\
\text { ting agent }\end{array}$ & \begin{tabular}{|l|}
$\begin{array}{l}\text { Bladder } \\
\text { tumors, }\end{array}$ \\
\end{tabular} & & Human plasma & - & HPLC-MS/MS & 5 & No & [96] \\
\hline Doxorubicin & Antibiotic & \begin{tabular}{|c|} 
Breast \\
ovarian, \\
bladder \\
and lung \\
cancer \\
\end{tabular} & $30-100 \mathrm{mg}$ & Human plasma & \begin{tabular}{|c|} 
Doxorubicinol \\
Doxorubicinolone \\
7-deoxy-doxorubicinol \\
7-deoxy- \\
doxorubicinolone \\
\end{tabular} & $\begin{array}{c}\text { HPLC- } \\
\text { Fluorescence }\end{array}$ & 0.3 & Yes & [243] \\
\hline Epirubicin & Antibiotic & $\begin{array}{c}\text { Bladder } \\
\text { cancer }\end{array}$ & $20-80 \mathrm{mg}$ & Human plasma & $\begin{array}{c}\text { Eirubicinol } \\
\text { 4'-O- } \beta \text {-d-glucuronyl- } \\
\text { 4'-epirubicin and 4'-O- } \\
\beta \text {-d-glucuronyl 13- } \\
\text { dihydro-epirubicin } \\
\end{array}$ & $\begin{array}{c}\text { HPLC- } \\
\text { Fluorescence }\end{array}$ & 0.3 & Yes & {$[243]$} \\
\hline Epirubicinol & Antibiotic & $\begin{array}{c}\text { Bladder } \\
\text { cancer }\end{array}$ & & Human plasma & - & $\begin{array}{c}\text { HPLC- } \\
\text { Fluorescence }\end{array}$ & 0.3 & $\mathrm{n} / \mathrm{a}$ & {$[243]$} \\
\hline \begin{tabular}{|c|}
$4^{\prime}-\mathrm{O}-\beta-\mathrm{d}-$ \\
glucuronyl-4'- \\
epirubicin and 4'-O- \\
$\beta$-d-glucuronyl 13- \\
dihydro-epirubicin \\
\end{tabular} & & $\begin{array}{l}\text { Bladder } \\
\text { cancers }\end{array}$ & - & Human plasma & - & $\begin{array}{c}\text { HPLC- } \\
\text { Fluorescence }\end{array}$ & $0.2,0.2$ & $\mathrm{n} / \mathrm{a}$ & [243] \\
\hline Gemcitabine & Nucleoside & $\begin{array}{c}\text { Bladder } \\
\text { cancer }\end{array}$ & $\begin{array}{l}500 \text { to } \\
2,000\end{array}$ & Human plasma & $\begin{array}{c}\text { dFdU (2'-2'- } \\
\text { difluorodeoxyuridine) }\end{array}$ & HPLC-MS/MS & 0.5 & Yes & {$[272]$} \\
\hline
\end{tabular}

Abbreviations: HPLC-UV: High performance liquid chromatography coupled to ultraviolet detector; HPLC-PDA: High performance liquid chromatography coupled to photo diode array detection; HPLC-MS/MS: High performance liquid chromatography coupled to tandem mass spectrometry; LLOQ: Lower limit of quantitation; *: Method is sensitive enough when it allows the systemic detection of the locally administered anti-cancer agents; n/a: Not applicable (because no systemic pharmacokinetic studies have been performed or the compound was not measured).

5 to 10 hours [174]. Consequently, the method for the determination of MTX in human plasma, described by Steinborner et al. with a LLOQ of $0.1 \mathrm{ng} / \mathrm{mL}$, is sufficient to measure these concentrations.

\subsubsection{Cytarabine}

Cytarabine (ara-C) is an antineoplastic antimetabolite used in the treatment of leukemia. Ara- $\mathrm{C}$ is metabolized intracellularly into the active triphosphate form to damage DNA by various mechanisms, such as inhibition of DNA 
repair through an effect on $\beta$-DNA polymerase and incorporation into DNA. Liposomal cytarabine is a slow-release formulation of cytarabine produced by encapsulating the aqueous drug solution in spherical multivesicular particles known as DepoFoam. The compound is slowly released from the DepoFoam into the cerebrospinal fluid, resulting in 40 times longer drug exposure compared to standard cytarabine. The LLOQ of the available analytical HPLC-UV method for the determination of cytarabine in human plasma, published by Fahmy et al, is $450 \mathrm{ng} / \mathrm{mL}$ [179]. Hence, Hsieh et al. described three elegant methods for the determination of highly polar cytarabine in mouse plasma by means of (i) porous graphitic carbon column (Hypercarb) coupled to tandem MS; (ii) ion-pairing liquid chromatography interfaced with atmospheric chemical ionization source and a tandem MS; (iii) supercritical fluid chromatography/tandem MS method with a LLOQ of $50 \mathrm{ng} / \mathrm{mL}$ for all three methods [180-182]. All three methods were complimentary to each other and investigated interesting properties of the Hypercarb, ion-paring and supercritical liquid chromatography. Porous graphitic carbon column is composed of flat sheets of hexagonally arranged carbon atoms, which is stable throughout the entire $\mathrm{pH}$ range and chemically inert to aggressive solvents. Moreover, due to its peculiar properties, Hypercarb enables the analysis and the chromatographic separation of analytes with extensive polarities [180]. Ion-paring reagents added into the mobile phase are used to improve chromatographic retention on the liphophilic stationary phase through the formation of neutral ion pairs. In this assay, the volatile perfluorinated carboxylic acid ion-pairing reagents, HFBA and NFPA, were added to mobile phase A (water) and $B$ (acetonitrile), respectively, with the goal to establish a robust HPLC-MS/MS assay for monitoring highly polar cytarabine in mouse plasma samples following a simple protein precipitation with methanol [181]. In their recently published article, the potential of packed-column supercritical fluid chromatography (pSFC)-MS/MS method as a complimentary coverage to the HPLC-MS/MS methods for the quantification of cytarabine in mouse plasma samples was investigated [182]. $\mathrm{CO}_{2}$, which is the most commonly used mobile phase in SFC, possesses low viscosity and high diffusivity. The coupling of $\mathrm{CO}_{2}$ /methanol normal phase pSFC to the APCI interface showed good potential for maximum separation efficiency and the detection of the analyte [182]. All three methods, described above, appeared to be complimentary and accurately and specifically measure cytarabine with a LLOQ of $50 \mathrm{ng} / \mathrm{mL}$.

i.t. cytarabine is used in the prophylaxis and treatment of acute lymphocytic leukemia and neoplastic meningitis [172,183-188]. The standard administered doses range from $15-70 \mathrm{mg}$.

Bomgaars et al. presented a phase I trial of i.t. liposomal cytarabine [185]. 18 patients received i.t. cytarabine at the doses of 25 to $50 \mathrm{mg}$. Blood samples were analyzed and plasma concentrations of cytarabine were rarely detectable, with only two plasma concentrations of 220 and $620 \mathrm{ng} / \mathrm{mL}$. Possibly, the above described methods with a LLOQ of 50 $\mathrm{ng} / \mathrm{mL}$, could have measured lower levels of cytarabine in plasma after i.t. administration.

\subsection{DNA Alkylating Agent}

\subsubsection{Thiotepa}

Thiotepa has been investigated for the treatment of leptomeningeal metastases (LM). LM are cancer cells that circulate along cerebrospinal fluid (CSF) pathways and seed the meningitis. This results in leptomeningeal neoplasia. Thiotepa is administered i.t. in a dose of $5-11.5 \mathrm{mg} / \mathrm{m}^{2}[189,190]$. However, some studies suggest that i.t. thiotepa does not appear to be advantageous over systemic administration in patients with brain and meningeal leukaemia [189]. Unfortunately, no study has been performed yet where systemic exposure to thiotepa was measured after i.t. therapy.

\subsubsection{Busulfan}

Busulfan (1,4-butanediol dimethanesulfonate) is a bifunctional alkylating agent which is commonly administered in preparative chemotherapy regimens for bone marrow transplantation for patients with heamatological malignancies and non-malignant disorders [191]. This alkylating agent has also been used in the treatment of chronic myelogenous leukemia. Recently, a water soluble microcrystalline formulation of Busulfan (Spartaject Busulfan) became available for experimental use [192].

Several methods using GC-electrochemical detection, GC-MS, HPLC-UV and HPLC-fluorescence have been described [191,193-197]. Because busulfan is a very polar compound with poor UV absorbancy, most of these methods require pre-column or online derivatization with either 8mercaptoquinoline [196], or 2,3,5,6-tetrafluorothiophenol to obtain di-TFTP-butane [194], or with sodium diethyldithiocarbamate [195], to form a non-polar compound with a specific UV absorbancy and to facilitate the detection. With the introduction of HPLC coupled with tandem MS, the development of a highly sensitive method for the determination of busulfan in human plasma could be accomplished. The methods described by Quernin et al. and dos Reis et al. report major advantages compared to previous methods $[191,193]$. They eliminated the derivatization and extraction of busulfan, which shortened the run time by at least $2.5 \mathrm{~h}$. Moreover, the LLOQ of $5 \mathrm{ng} / \mathrm{mL}$ was achieved by means of HPLC-MS. Both groups describe the extraction of busulfan from $200 \mu \mathrm{L}$-plasma aliquots using liquid-liquid extraction with ethyl acetate. Quernin et al. used HPLC coupled with positive mode MS and a chromatographic run time of 10 minutes. Hence, dos Reis et al. employ a more selective tandem MS and a rapid chromatographic run time of only 3.5 minutes [191].

Recently, a phase I trial of i.t. Spartaject Busulfan in children with neoplastic meningitis was executed and presented by Gururangan et al. [192]. Patients received doses varying from $5-17 \mathrm{mg}$. I.t. busulfan was well tolerated in children with neoplastic meningtitis from brain tumors, and the recommended dose for future phase II is $13 \mathrm{mg}$. The concentration of busulfan in plasma was measured using the analytical method by Lindley et al. with a LLOQ of 50 $\mathrm{ng} / \mathrm{mL}$ and the observed plasma concentrations were between $150-380 \mathrm{ng} / \mathrm{mL}$. Consequently, this method and obviously the bioanalytical assay presented by dos Reis et al, have a sufficient LLOQ to quantitate the traces of drug in plasma of i.t. administered busulfan. 


\subsubsection{Mafosfamide}

Cyclophosphamide (2-[bis(2-chloroethyl)amino]tetrahydro-2H-1,3,2-oxazaphosphorine 2-oxide; CP) is a cytotoxic alkylating agent widely used in the treatment of various malignancies. Cyclophosphamide is a prodrug and requires oxidation by cytochrome P450 enzyme system (CYP) to produce its pharmacologically active metabolite 4-hydroxycyclophosphamide (4OHCP). This active metabolite is unstable and undergoes spontaneous degradation to biologically active species such as phosphoramide mustard. Mafosfamide (4-sulfoethylthio-cyclophosphamide L-lysine) is a preactivated chemically stable thioethane sulfonic acid derivative of cyclophosphamide, which does not require hepatic activation and undergoes spontaneous conversion to the active species in aqueous media (Fig. 16, as depicted by Blaney et al) $[198,199]$. Due to the rapid degradation of mafosfamide into the active $4 \mathrm{OHCP}$, the determination of $4 \mathrm{OHCP}$ is of crucial importance. However, measuring 4OHCP levels in plasma is cumbersome, because of its instability. This compound requires trapping by derivatization to stop the enzymatic metabolism and chemical degradation. In the literature, derivatization with methyl-hydroxylamine, semicarbazide, $p$-nitrophenylhydrazine, potassium cyanide and 4-aminophanol/hydroxyl-aminehydro-chloride have been described [96,199-203]. The most simple and rapid assay with a LLOQ of $50 \mathrm{ng} / \mathrm{mL}$ for $4 \mathrm{OHCP}$ was described by de Jonge et al. [96]. Recently, Ekhart et at. presented an improved assay by means of using a stable isotope as internal standard and consequently reducing the runtime from 9 to 6 minutes [204]. Immediately after sample collection, the compound was derivatized with semicarbazide, followed by simple protein precipitation using methanol-acetonitrile (1:1, $\mathrm{v} / \mathrm{v})$ containing isotopically labeled $\mathrm{CP}$ and hexamethylphosphoramide as internal standards, utilizing $100 \mu \mathrm{L}$ plasma aliquots. With the use of reversed phase chromatography with a flow of $0.4 \mathrm{ml} / \mathrm{min}$, the total run time of only 6 minutes could be obtained. The employment of an alkaline mobile phase containing ammonium hydroxide combined with the HPLC-MS/MS in the positive ion mode yielded a LLOQ for $4 \mathrm{OHCP}$ of $50 \mathrm{ng} / \mathrm{mL}$.

In vitro and in vivo studies showed a significant activity against a number of transplantable tumors and solid tumors, respectively. Moreover, it was demonstrated that the cytotoxic activity of mafosfamide was comparable to or even exceeding that of activated cyclophosphamide (4hydroperoxy-cyclophosphamide, a preactivated cyclophosphamide derivative that has been used to purge tumor cells from stem-cell collections before reinfusion). A preclinical and phase I study was executed by Blaney et al. $[205,206]$ The patients received i.t. doses ranging from 1 to $6.5 \mathrm{mg}$. I.t. mafosfamide was generally well tolerated. The dose limiting toxicity was irritability and pain at the higher dose levels. The plasma concentrations were measured by a method described by Alacron et al. [207] with a LLOQ of $55 \mathrm{ng} / \mathrm{mL}$ and no 4OHCP was detected. Consequently, this method was not sensitive enough. Currently, the most sensitive assay has been developed by Ekhart et al. with LLOQ for 4OHCP of $50 \mathrm{ng} / \mathrm{mL}$ [204]. Possibly, this method could have detected $4 \mathrm{OHCP}$ after i.t. mafosfamide.

\subsection{Topo-Isomerase Inhibitors}

\subsubsection{Topotecan}

Studies to investigate the CSF pharmacokinetics of topotecan following systemic administration in a non-human primate model demonstrated that the CSF penetration of the active lactone form of topotecan was approximately $30 \%$ $[208,209]$. Due to the excellent CSF penetration and the lack of neurotoxicity after systemic administration, studies were performed to evaluate the feasibility of i.t. topotecan in a non-human primate model. Following direct intraventricular topotecan administration, a 450 -fold greater CSF exposure could be achieved with $1 / 100^{\text {th }}$ of systemic dose; namely, 0.1 $\mathrm{mg}$ i.t. administered topotecan was well tolerated [208,210,211].

Several studies with i.t. administered topotecan were executed and, compared with systemic topotecan, i.t. administration provided a significant pharmacokinetic advantage in terms of CSF drug exposure and did not produce any significant neurotoxicity $[208,209,211]$. The maximum tolerated dose is $0.4 \mathrm{mg}$.

Unfortunately, in the recently described phase I clinical trials i.t. topotecan was measured in CSF fluids and not in plasma, and no conclusion can be made regarding the usefulness of the described bioanalytical assays to measure topotecan in plasma after i.t. administration.

\section{INTRAVESICAL ADMINISTERED ANTI-CANCER AGENTS}

Bladder chemotherapy instillation, or intravesical chemotherapy, is used in the treatment of superficial bladder cancer by filling the bladder with medication (Table 6). During a bladder instillation, the bladder is filled with a therapeutic solution that flows in through a narrow tube inserted through the urethra and into the bladder. The instillation is held for varying periods of time, from 1 to 2 hours or more, before being drained or voided. Superficial bladder cancers are usually an early form of cancer, which may recur after initial surgical removal. However, by using treatment which sets medication directly in contact with the bladder wall, it may be possible to prevent recurrence or lengthen the time until recurrence. In the case of advanced stage of bladder cancer, surgical removal or endoscopic thansurethral resection of tumor (TUR-B) is executed, however, due to the high rate of recurrence of the cancer, intravesical chemotherapy is also used as an adjuvant therapy [212-230].

Usually, the intravesically administered drugs are given at a high dosage for a high local efficacy; however it is extremely important that, while penetrating the cellular levels of the bladder wall to reach the cancer cells, the drug won't pass into the systemic circulation, which can lead to systemic toxicity of the agent. Drug diffusion across the bladder wall is dependant on the molecular weight and lipid solubility of the applied agent.

\subsection{DNA Alkylating Agent}

\subsubsection{Mitomycin $C$}

MMC is a bioreductive agent and it is activated by intracellular reductive enzymes to form cytotoxic species, which 

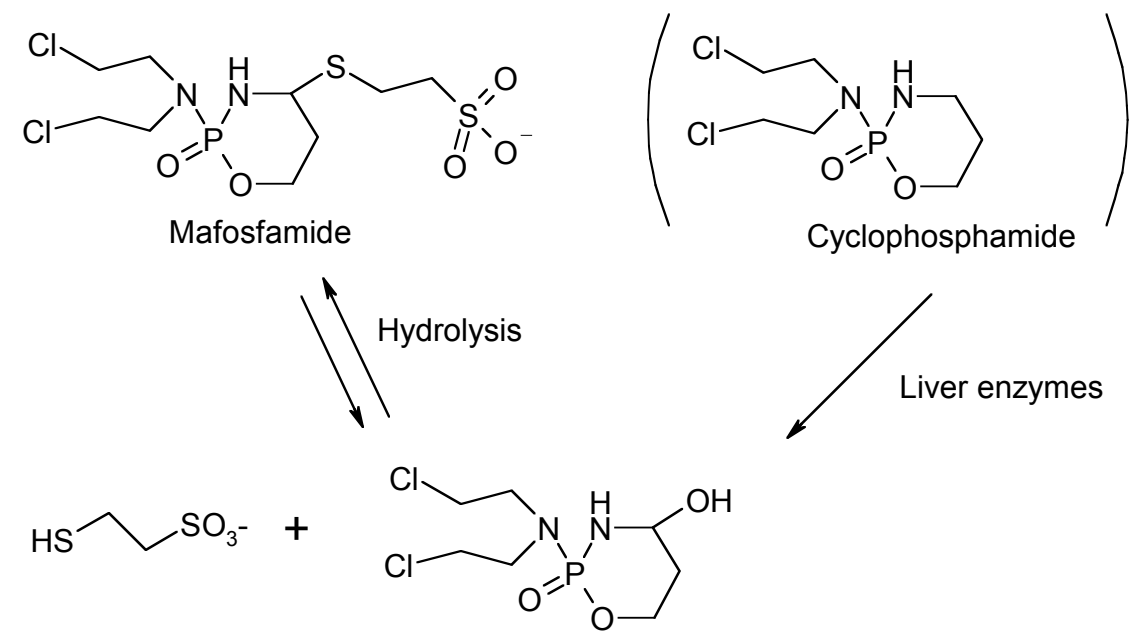

2-mercapto ethane sulfonate (mesna)

4-hydroxycyclophosphamide

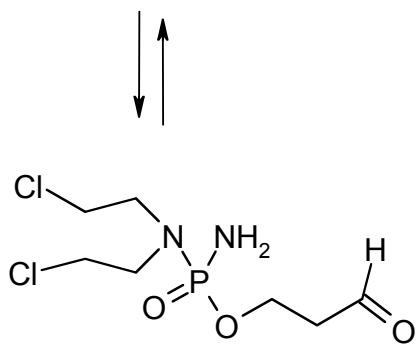

Aldophosphamide

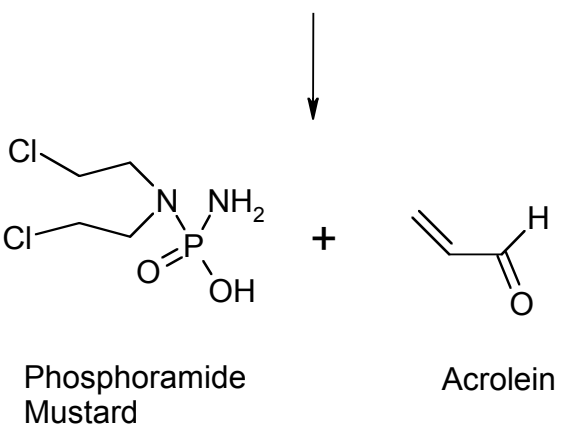

Fig. (16). Structure of mafosfamide and its metabolites/degradation products (as proposed by Blaney et al. [198]).

then alkylate the DNA. When administered intravesically, the systemic toxicity is limited, however local toxicity is common. Chemical cystitis occurs in approximately $16 \%$ of patients. The dose varies between 2-60 mg MMC. It is diluted with water and applied intravesically in the concentration of $0.5-2 \mathrm{mg} / \mathrm{mL}$ with $1-2$ hours of retention in the bladder [212-219]. MMC has a molecular weight of $334 \mathrm{Da}$, and it is relatively hydrophobic. Therefore its diffusion and absorption rate will be relatively slow, resulting in a slower decline in concentration over the depth of the bladder wall and making this agent a suitable drug for deeper bladder wall tumors [212].

Several pharmacokinetic studies have been executed to determine the penetration of $\mathrm{MMC}$ in human bladder $[231,232]$. Treatment consisted of transurethral tumor resection followed by six weekly intravesical treatments with
MMC (20 mg/40 mL water) for a total of 28 treatments. The plasma concentrations averaged 2.1 and $181 \mathrm{ng} / \mathrm{mL}$ and, consequently, the ultrasenstive analytical method for the determination of MMC with the LLOQ of $0.5 \mathrm{ng} / \mathrm{mL}$ (as described in section 4.3.1), is adequate to determine the traces of MMC in human plasma when administered intravesically. Detected concentrations were significantly lower than the mitomycin plasma concentrations of $400 \mathrm{ng} / \mathrm{mL}$ leading to myelosuppression [233].

\subsubsection{EO9 (Apaziquone)}

EO9 (EOquin $\AA$ or apaziquone) is an indoloquinone derivative of MMC. EO9 also belongs to the class of anticancer agents, known as bioreductive drugs, which are inactive prodrugs that require metabolic activation to generate cytotoxic species. Although, EO9 is indeed structurally related to $\mathrm{MMC}$, it has a different mechanism of action and 
activity profile. The main metabolite of EO9 is an open ring analogue, EO5a, which is inactive. Recently, we identified another degradation product of EO9, EO9-CL, where $\mathrm{Cl}$ is covalently attached to the aziridine ring-opened EO9 molecule (Fig. 17) [234-236]. The administered dose is usually 4 $\mathrm{mg}$ of formulated EO9/40 $\mathrm{mL}$ of instillation solution. The pharmaceutical formulation consisted of $4 \mathrm{mg}$ of EO9, 25 $\mathrm{mg}$ mannitol, $10 \mathrm{mg}$ sodium bicarbonate and $40 \mathrm{~mL}$ of the diluent. The diluent formulation contains $10 \mathrm{mg} / \mathrm{mL}$ sodium bicarbonate, $0.2 \mathrm{mg} / \mathrm{mL}$ EDTA, and $0.6 \mathrm{~mL}$ propylene gly$\mathrm{col}$ in $2.0 \mathrm{~mL}$ sterile water for injection. The $\mathrm{pH}$ of the instillation solution is 8.5, which is where EO9 is most stable. If $\mathrm{pH}$ shifts in any directions from 8.5, EO9 degrades into inactive degradation products. Recently, an enhanced resolution HPLC-MS/MS method for the determination of EO9 and its inactive metabolite EO5a was developed in our department with a LLOQ of $0.5 \mathrm{ng} / \mathrm{mL}$ plasma [237]. To extract the drug from human plasma, liquid-liquid extraction was employed using ethylacetate and reversed phase HPLC coupled to tandem MS was applied. The detection was executed by a Finnigan TSQ Quantum Ultra equipped with the electrospray ion source operated in positive mode, with enhanced massresolution capability. It demonstrated improved sensitivity with a factor 10-20 for EO9 and EO5a over 3-decades dynamic range, with acceptable accuracy and precision, when compared with the previously described assay for EO9 and EO5a, developed by our group, using an API 2000 [234,237].

In the two phase II studies, which recently were executed, EO9 proved to be very active and showed a complete response in $67 \%$ of the 41 included patients [223,224]. A phase III study is currently ongoing in the USA.

To determine the systemic absorption of EO9, a multicenter, non-randomized, open-label phase II study was performed. Patients with high risk superficial bladder cancer were treated once a week for 6 weeks with intravesical instillation of EOquin ${ }^{\circledR}$ (4 mg EO9 in $40 \mathrm{~mL}$ instillate). Moreover, another phase II clinical study to determine the toxicity of the drug was performed in 20 patients. Patients with $\leq 4$ tumors received EOquin $\AA$ within 6 hours of Transurethral Resection of Bladder Tumor (TUR-B). Plasma samples were measured using the above HPLC-MS/MS method with the LLOQ for EO9 and EO5a of $0.5 \mathrm{ng} / \mathrm{mL}$. No detectable levels of either EO9 or EO5a were measured in the samples from both studies.

\subsubsection{Thiotepa}

Thiotepa is given intravesically in a variety of schedules to treat superficial bladder cancer. Usually, it is administered, as most of the intravesically administered agents, after TUR-B. Since thiotepa has a molecular weight of only 188 $\mathrm{Da}$ and it is lipophilic, diffusion rate is rapid and absorption is extensive. Systemic absorption may result in myelosuppression. The standard intravesical dose is $30-60 \mathrm{mg}$, with a concentration of $1 \mathrm{mg} / \mathrm{mL}$ of normal saline or water [212,213,225].

Masters et al. described thiotepa pharmacokinetics during intravesical chemotherapy [225]. Thiotepa was given intravesically in a variety of schedules to treat superficial bladder cancer (from 30-60 mg). Blood samples were obtained

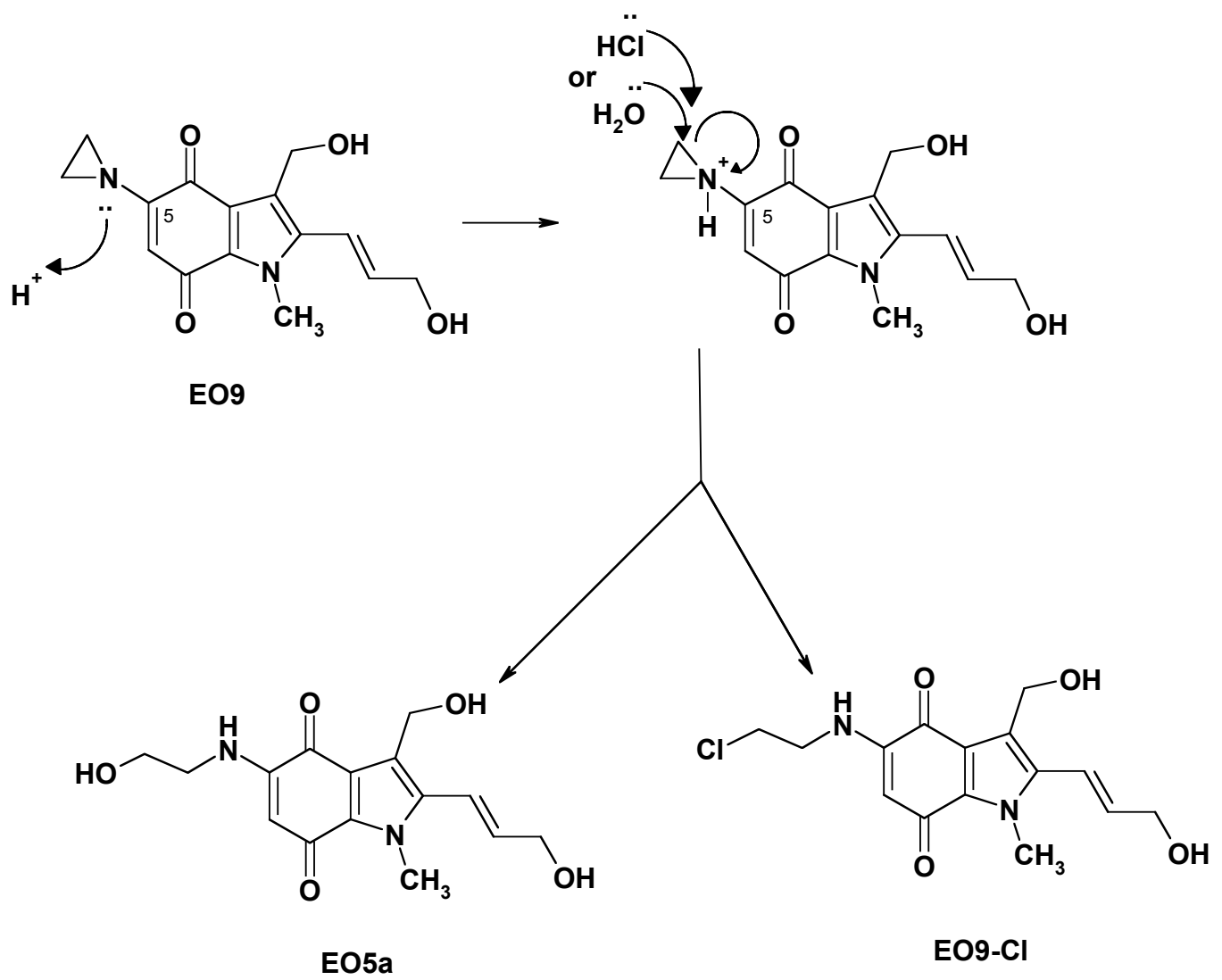

Fig. (17). Proposed degradation mechanism of EO9 in slightly acidic urine. 
for $8 \mathrm{~h}$ following instillation, and both thiotepa and tepa were measured. The lowest thiotepa concentration measured in the plasma of the patients was $5 \mathrm{ng} / \mathrm{mL}$ (and the highest approximately $200 \mathrm{ng} / \mathrm{mL}$ ) and no tepa was detected in plasma, using the analytical assay by McDermott et al. with a LLOQ of $5 \mathrm{ng} / \mathrm{mL}$ [238]. A more sensitive method is thus needed to determine the metabolite of thiotepa, tepa, in human plasma after the intravesical administration of thiotepa.

\subsection{Antibiotics}

\subsubsection{Doxorubicin}

Doxorubicin (adriamycin) is an anthracycline antibiotic that acts as an intercalating agent and an inhibitor of topoisomerase II [212]. Doxorubicin is most toxic in the S-phase. This drug undergoes an extensive metabolism by the liver and is excreted primarily in the bile. Enzyme-mediated reduction and deglycosidation of doxorubicin results in the formation of several structurally related hydroxylated and aglycone metabolites. Doxorubicinol is produced by cytosolic carbonyl reductase through NADPH-dependant aldo-keto reduction of a carbonyl moiety at the C-13 position. [239]. Doxorubicinone and doxorubicinolone are produced by deglycosidation at the daunosamine sugar at C-7 position. The formed hydroxyl group may be metabolized to 7deoxydoxorubicinone and 7-deoxydoxorubicinolone (Fig. 18).

Doxorubicin displays a broad spectrum of antitumor activity against acute leukemias, Hodgkin and non-Hodgkin's lymphomas, breast cancer, lung cancer and bladder cancer [239]. Patients who fail to respond to alkylating agents (MMC or thiotepa) may be best treated with an intercalating agent, such as doxorubicin or epirubicin, or visa versa. When administered intravesically, the systemic absorption is limited, due to the high molecular weight of 580 Da. Systemic reactions consist of mild nausea and vomiting, diarrhea and fever. The major dose limiting factor is cardiotoxicity. Local side effects consist of chemical cystitis. Doxorubicin is administered in doses of 30-100 $\mathrm{mg}$ and diluted with saline solution to a concentration of $0.5-2 \mathrm{mg} / \mathrm{mL}$ [212-214]. Over the years, there have been numerous analytical methods developed to determine anthracyclins and their metabolites in biological matrices [239-257]. Camaggi et al. developed a highly sensitive assay for the determination of doxorubicin and its fluorescent metabolites, doxorubicinol, doxorubicinone and doxorubicinolone, 7-deoxydoxorubicinone and 7deoxydoxorubicinolone, in human plasma utilizing HPLC with fluorescence detection, which yielded a LLOQ of 0.3 $\mathrm{ng} / \mathrm{mL}$ [241]. Sample aliquots of $1000 \mu \mathrm{L}$ were processed using solid phase extraction, which yielded a higher recovery compared to other methods.

The use of capillary electrophoresis with laser-induced fluorescence detection in the separation and determination of doxorubicin and its metabolites in cells have been demonstrated [255,257]. Recently, using this technique, Anderson et al. described the quantitation of doxorubicin and its metabolites in cell extracts with a LLOQ ranging from 0.1 to $1.1 \mathrm{fmol}$ per cell in single cell analysis [257,258]. Using borate and sodium dodecyl sulfate $(\mathrm{pH} 9.3)$ as a separation buffer (for the metabolites), the $488 \mathrm{~nm}$ argon-ion laser line for fluorescence excitation, and a $635 \pm 27.5 \mathrm{~nm}$ bandpass filter for detection, the limit of detection for doxorubicin in cells was $61 \pm 13 \mathrm{zmol}$ [257].

Moreover, fluorescence detection and laser-induced fluorescence detection proved to yield a lower LLOQ in plasma for doxorubicin compared with the previously described electrochemical detection [239-257].

Wientjes et al. performed a study with intravesical doxorubicin to investigate the penetration of doxorubicin in human bladders [259]. The commonly used dosing solution of $40 \mathrm{mg}$ (doxorubicin) $/ 20 \mathrm{ml}$ instillation was instilled prior to the start of surgery and maintained for 60-115 minutes until just prior to bladder excision. The lowest detected plasma levels were approximately $0.4 \mathrm{ng} / \mathrm{mL}$ after 3 hours of administration (LLOQ of the method is not mentioned). Consequently, the available analytical methods with a LLOQ of $0.3 \mathrm{ng} / \mathrm{mL}$ for doxorubicin is sufficient to measure low levels of doxorubicin which might have leaked into the systemic circulation.

\subsubsection{Epirubicin}

Epirubicin, a derivative of doxorubicin, was developed to reduce toxicity while maintaining an anti-tumor effect similar to that of doxorubicin [221,222]. When given intravesically, the main side effects are irritative bladder symptoms. The reported systemic absorption of this drug is minimal [213]. The standard dose varies between 20 and $80 \mathrm{mg}$ diluted in saline at a concentration of $0.5-1.6 \mathrm{mg} / \mathrm{mL}$ $[212,220]$. Several bioanalytical methods have been developed to determine epirubicin and its metabolites in human plasma [243,247,260-262]. The most sensitive assay was developed by Camaggi et al, as described in 10.2.1 [243]. The LLOQ's of epirubicin and its metabolites, epirubicinol, 4'-O- $\beta$-d-glucuronyl-4'-epirubicin and 4'-O- $\beta$-d-glucuronyl 13-dihydro-epirubicin were $0.3,0.2,0.2$ and $0.2 \mathrm{ng} / \mathrm{mL}$, respectively [243].

Tsushima et al. investigated the absorption of epirubicin instilled intravesically immediately after transurethral resection of superficial bladder cancer [263]. Epirubicin was administered in the doses varying from 20 and $50 \mathrm{mg}$ and the systemic plasma concentrations of this compound were measured. After the administration of $50 \mathrm{mg}$, plasma concentrations of $5 \mathrm{ng} / \mathrm{mL}$ could be measured, however, no detectable levels were observed after the dose of $20 \mathrm{mg}$ (the LLOQ of the method is not mentioned). Consequently, with the ultrasensitive analytical method for the quantitation of epirubicin with the LLOQ of $0.3 \mathrm{ng} / \mathrm{mL}$, developed by Camaggi et al., trace levels in plasma of the intravesically administered epirubicin should be reasonably found.

\subsection{Nucleosides}

\subsubsection{Gemcitabine}

Gemcitabine (2'-2'-difluorodeoxycytidine) is a pyrimidine analog that exhibits antitumor activity against a variety of solid tumors. In blood, gemcitabine is rapidly deaminated by cytidine deaminase, resulting in the inactive metabolite dFdU (2'-2'-difluorodeoxyuridine) (Fig. 19). Several HPLC-UV, HPLC-PDA and HPLC-MS/MS methods for the quantitation of gemcitabine and dFdU in human plasma have been described [264-271]. Thus for, the most sensitive HPLC-MS/MS method for the determination of 
<smiles>COc1cccc2c1C(=O)c1c(O)c3c(c(O)c1C2=O)CC(O)(C(=O)CO)CC3=O</smiles><smiles></smiles><smiles>COc1cccc2c1C(=O)c1c(O)c3c(c(O)c1C2=O)CC(O)([13C](=O)CO)CC3</smiles>

7-deoxy-doxorubicinone Doxorubicin<smiles>CC</smiles><smiles>COc1cccc2c1C(=O)c1c(O)c3c(c(O)c1C2=O)CC(O)([13C](=O)CO)CC3=O</smiles><smiles>COc1cccc2c1C(=O)c1c(O)c3c(c(O)c1C2=O)CC(O)([C@H](O)CO)CC31CC2CC(CC(N)C2O)O1</smiles><smiles>COc1cccc2c1C(=O)c1c(O)c3c(c(O)c1C2=O)CC(O)([C@H](O)CO)CC3</smiles>

\section{7-deoxy-doxorubicinolone}

Doxorubicinol<smiles>COc1cccc2c1C(=O)c1c(O)c3c(c(O)c1C2=O)CC(O)([C@H](O)CO)CC3=O</smiles>

Fig. (18). Structure of doxorubicin and its metabolites.

gemcitabine and its inactive metabolite $\mathrm{dFdU}$ was developed in our department with the LLOQ for gemcitabine of 0.5 $\mathrm{ng} / \mathrm{mL}$ and for $\mathrm{dFdU}$ of $5 \mathrm{ng} / \mathrm{mL}$ [272]. Gemcitabine and $\mathrm{dFdU}$ were extracted from $200-\mu \mathrm{L}$ aliquot human plasma using solid phase extraction. Dried extracts were reconstituted in $1 \mathrm{mM}$ ammonium acetate - acetonitrile $(97: 3, \mathrm{v} / \mathrm{v})$ and $10 \mu \mathrm{L}$-volumes were injected onto the HPLC system. Separation was achieved on a $150 \times 2.1 \mathrm{~mm} \mathrm{C18}$ bonded phase endcapped with polar groups (Synergi Hydro-RP column) using the eluent composed of $1 \mathrm{mM}$ ammonium acetate $\mathrm{pH} 6.8$ - acetonitrile $(94: 6, \mathrm{v} / \mathrm{v})$. Detection was performed by positive ion electrospray followed by tandem MS, which yielded the lowest LLOQ published thus far of 0.5 $\mathrm{ng} / \mathrm{mL}$ for gemcitabine [272].

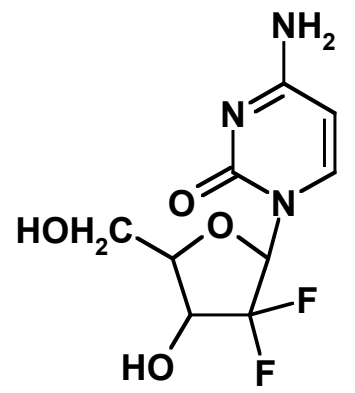

Gemcitabine

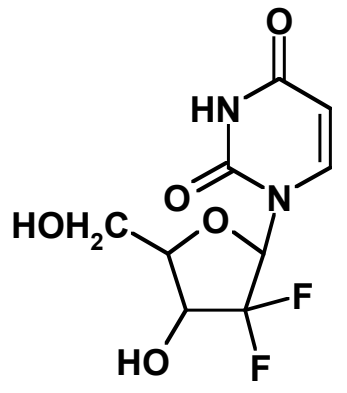

$\mathrm{dFdU}$
Fig. (19). Structural formula's of Gemcitabine and its metabolite $\mathrm{dFdU}$. 
Recent studies have shown gemcitabine to produce robust response rates in patients with superficial bladder cancer. Therefore, intravesical application of gemcitabine was tested, which was well tolerated with minimal systemic toxicity and promising efficacy in treatment of superficial bladder cancer [230].

Witjes et al. and Laufer et al. described two separate phase I and pharmacokinetic studies [230,273,274]. Gemcitabine was administered in the dose of 500 to $2,000 \mathrm{mg}$. Both studies concluded that intravesical gemcitabine, at doses up to $2 \mathrm{~g} /$ week is well tolerated, and associated with minimal systemic absorption. Moreover intravesical gemcitabine has promising efficacy in treatment of superficial bladder cancers. The lowest gemcitabine concentrations of $200 \mathrm{ng} / \mathrm{mL}$ were observed in plasma of four patients and the lowest concentrations of $10 \mathrm{ng} / \mathrm{mL}$ were observed for $\mathrm{dFdU}$. The LLOQ of the above described ultrasensitive method for the determination of gemcitabine and $\mathrm{dFdU}$ in human plasma is thus far sufficient for this application.

\section{CONCLUSIONS AND PERSPECTIVES}

The route of administration significantly influences the concentration of the drug in the systemic circulation, toxicity and the efficacy of the drug. Most anti-cancer agents are administered i.v. because this route is the most direct one and leads to immediate and complete bioavailability. At the same time, this is usually the most toxic route of administration because high concentrations of the cytotoxic agents may be delivered to the normal tissues and cells and consequently damage them. Moreover, the i.v. administration usually needs to be performed in the hospitalized environment, which can be inconvenient for the patient. Oral administration is patient friendly, but suffers from patient noncompliance and insufficient bioavailability, as observed often with antitumour agents.

In this review we have discussed the advantages and liabilities of the local administration routes, such as cutaneous, i.p, i.t. and intravesical chemotherapies. Important advantages of these routes are high local drug concentrations at the site of action with high local efficacy. However, because sometimes very high doses of the anti-cancer drugs are applied, it is of pivotal importance that none or only small amounts are absorbed into the bloodstream. To determine the low concentrations of locally administered drugs and their degradation products or metabolites that enter the systemic circulation, ultrasensitive bioanalytical methods have been developed in the last 10-20 years. Not all assays, however, are sensitive enough to determine systemic traces of the locally administered agents. Especially with topically applied agents, any systemic exposure has not been investigated thus far. Interestingly, relatively old HPLC-UV techniques still cover a significant part of the assays developed for anticancer agents as discussed in this review. However, MS detection provides in all cases, without doubt, a better sensitivity and selectivity than UV detection. In the recent years, the HPLC-MS technique has shown a steep, fascinating development into the most important tool in the quantitative determination of known and experimental anti-cancer agents and identification of metabolites. Hence the more sensitive HPLC-MS/MS assays should be developed to quantitate systemic exposure of locally administered agents, which is pivotal to predict and to understand their toxicity in the early stage of the development and later clinical use.

\section{REFERENCES}

[1] Kesari, S.; Schiff, D.; Doherty, L.; Gigas, D. C.; Batchelor, T. T.; Muzikansky, A.; O'Neill, A.; Drappatz, J.; Chen-Plotkin, A. S.; Ramakrishna, N.; Weiss, S. E.; Levy, B.; Bradshaw, J.; Kracher, J.; Laforme, A.; Black, P. M.; Folkman, J.; Kieran, M.; Wen, P. Y. Neuro. Oncol., 2007, 9, 354 .

[2] Zhou, Q.; Guo, P.; Wang, X.; Nuthalapati, S.; Gallo, J. M. J. Pharmacol. Exp. Ther., 2007, 321, 265.

[3] Beumer, J. H.; Garner, R. C.; Cohen, M. B.; Galbraith, S.; Duncan, G. F.; Griffin, T.; Beijnen, J. H.; Schellens, J. H. Invest New Drugs, 2007, 25, 327.

[4] Brouwers, E. E.; Huitema, A. D.; Schellens, J. H.; Beijnen, J. H. Submitted for publication 2008.

[5] Brouwers, E. E.; Huitema, A. D.; Bakker, E. N.; Douma, J. W.; Schimmel, K. J.; van, W. G.; de Wolf, P. J.; Schellens, J. H.; Beijnen, J. H. Int. Arch. Occup. Environ. Health, 2007, 80, 689.

[6] Stokvis, E.; Rosing, H.; Beijnen, J. H. Mass Spectrom. Rev., 2005, 24, 887-917.

[7] Sleiman, M.; Ferronato, C.; Fenet, B.; Baudot, R.; Jaber, F.; Chovelon, J. M. Anal. Chem., 2006, 78, 2957.

[8] Banga, R.; Ramsden, J.; Cox, G. J. Laryngol. Otol., 2005, 119, 403.

[9] Grem, J. L. Invest. New Drugs, 2000, 18, 299.

[10] Wang, K.; Nano, M.; Mulligan, T.; Bush, E. D.; Edom, R. W. J. Am. Soc. Mass Spectrom., 1998, 9, 970.

[11] Matsushima, E.; Yoshida, K.; Kitamura, R.; Yoshida, K. J. Chromatogr. B Biomed. Sci. Appl., 1997, 691, 95.

[12] Meijer, B. U.; de Waard-van der Spek FB Contact Dermatitis, 2007, 57,58 .

[13] Perrett, C. M.; McGregor, J. M.; Warwick, J.; Karran, P.; Leigh, I. M.; Proby, C. M.; Harwood, C. A. Br. J. Dermatol., 2007, 156, 320.

[14] Takahashi, H.; Funabiki, K.; Hasebe, S.; Fukuda-Yamamoto, T.; Kaieda, S.; Iwanaga, T.; Kumagami, H.; Takasaki, K. Auris Nasus Larynx, 2005, 32, 353.

[15] McGillis, S. T.; Fein, H. Semin. Cutan. Med. Surg., 2004, 23, 174.

[16] van Ruth S.; Jansman, F. G.; Sanders, C. J. Pharm. World Sci., 2006, 28,159 .

[17] Joulia, J. M.; Pinguet, F.; Grosse, P. Y.; Astre, C.; Bressolle, F. J. Chromatogr. B Biomed. Sci. Appl., 1997, 692, 427.

[18] Suppasansatorn, P.; Wang, G.; Conway, B. R.; Wang, W.; Wang, Y. Cancer Lett., 2006, 244, 42.

[19] Bleehen, N. M.; Newlands, E. S.; Lee, S. M.; Thatcher, N.; Selby, P.; Calvert, A. H.; Rustin, G. J.; Brampton, M.; Stevens, M. F. J. Clin. Oncol., 1995, 13, 910.

[20] Middleton, M. R.; Grob, J. J.; Aaronson, N.; Fierlbeck, G.; Tilgen, W.; Seiter, S.; Gore, M.; Aamdal, S.; Cebon, J.; Coates, A.; Dreno, B.; Henz, M.; Schadendorf, D.; Kapp, A.; Weiss, J.; Fraass, U.; Statkevich, P.; Muller, M.; Thatcher, N. J. Clin. Oncol., 2000, 18, 158.

[21] Shen, F.; Decosterd, L. A.; Gander, M.; Leyvraz, S.; Biollax, J.; Lejeune, F. J. Chromatogr. B Biomed. Appl., 1995, 667, 291.

[22] Kim, H.; Likhari, P.; Parker, D.; Statkevich, P.; Marco, A.; Lin, C. C.; Nomeir, A. A. J. Pharm. Biomed. Anal., 2001, 24, 461.

[23] Chowdhury, S. K.; Laudicina, D.; Blumenkrantz, N.; Wirth, M.; Alton, K. B. J. Pharm. Biomed. Anal., 1999, 19, 659.

[24] Kim, H. K.; Lin, C. C.; Parker, D.; Veals, J.; Lim, J.; Likhari, P.; Statkevich, P.; Marco, A.; Nomeir, A. A. J. Chromatogr. B Biomed. Sci. Appl., 1997, 703, 225.

[25] Hoeger, P. H.; Nanduri, V. R.; Harper, J. I.; Atherton, D. A.; Pritchard, J. Arch. Dis. Child, 2000, 82, 483.

[26] Reepmeyer, J. C. J. Chromatogr. A, 2005, 1085, 262.

[27] Sperry, M. L.; Skanchy, D.; Marino, M. T. J. Chromatogr. B Biomed. Sci. Appl., 1998, 716, 187.

[28] Esteve, E.; Bagot, M.; Joly, P.; Souteyrand, P.; Beylot-Barry, M.; Vaillant, L.; Delaunay, M.; Avril, M. F.; Laroche, L.; Grange, F.; Thomine, E.; Wechsler, J. Arch. Dermatol., 1999, 135, 1349.

[29] Hultgren, T. L.; Jones, D.; Duvic, M. Am. J. Clin. Dermatol., 2007, 8,51 .

[30] Reddy, V. B.; Ramsay, D.; Garcia, J. A.; Kamino, H. Am. J. Dermatopathol., 1996, 18, 19.

[31] Cummings, J.; MacLellan, A.; Smyth, J. F.; Farmer, P. B. Anal. Chem., 1991, 63, 1514. 
[32] Liu, J.; Hu, W.; Chen, H.; Ni, Q.; Xu, H.; Yang, X. Int. J. Pharm., 2007, 328, 191.

[33] Queille-Roussel, C.; Poncet, M.; Mesaros, S.; Clucas, A.; Baker, M.; Soloff, A. M. Clin. Ther., 2001, 23, 205.

[34] Lehman, P. A.; Franz, T. J. J. Pharm. Sci., 1996, 85, 287.

[35] Willoughby, R. C.; Browner, R. F. Anal. Chem., 1984, 56, 2626.

[36] Behymer, T. D.; Bellar, T. A.; Budde, W. L. Anal. Chem., 1990, $62,1686$.

[37] Maenpaa, J.; Dooley, T.; Wurz, G.; VandeBerg, J.; Robinson, E.; Emshoff, V.; Sipila, P.; Wiebe, V.; Day, C.; DeGregorio, M. Cancer Chemother. Pharmacol., 1993, 32, 392.

[38] Webster, L. K.; Crinis, N. A.; Stokes, K. H.; Bishop, J. F. J. Chromatogr., 1991, 565, 482.

[39] Holleran, W. M.; Gharbo, S. A.; DeGregorio, M. Anal. Lett., 1987, 20,871 .

[40] Rouanet, P.; Linares-Cruz, G.; Dravet, F.; Poujol, S.; Gourgou, S.; Simony-Lafontaine, J.; Grenier, J.; Kramar, A.; Girault, J.; Le, N. E.; Maudelonde, T. J. Clin. Oncol., 2005, 23, 2980.

[41] Girault, J.; Istin, B.; Fourtillan, J. B. Biol. Mass Spectrom., 1993, 22,395 .

[42] Leonard, R.; Hardy, J.; van, T. G.; Houston, S.; Simmonds, P.; David, M.; Mansi, J. J. Clin. Oncol., 2001, 19, 4150.

[43] Meerum Terwogt, J. M.; Mandjes, I. A.; Sindermann, H.; Beijnen, J. H.; ten Bokkel Huinink, W. W. Br. J. Cancer, 1999, 79, 1158.

[44] Smorenburg, C. H.; Seynaeve, C.; Bontenbal, M.; Planting, A. S.; Sindermann, H.; Verweij, J. Antican. Drugs, 2000, 11, 825.

[45] Clive, S.; Gardiner, J.; Leonard, R. C. Cancer Chemother. Pharmacol., 1999, 44 Suppl, S29.

[46] Lemke, A.; Kayser, O. Pharmazie, 2006, 61, 406

[47] Dorlo, T. P. C.; Hillebrand, M. J.; Rosing, H.; Eggelte, T. A.; de Vries, P. J.; Beijnen, J. H. J. Chromatogr. B Analyt. Technol. Biomed. Life Sci., 2008, [Epub ahead of print].

[48] Yeatts, R. P.; Engelbrecht, N. E.; Curry, C. D.; Ford, J. G.; Walter, K. A. Ophthalmology, 2000, 107, 2190.

[49] Cummings, J.; Chirrey, L.; Willmott, N.; Halbert, G. W.; Smyth, J. F. J.Chromatogr., 1993, 612, 105.

[50] Choi, K. E.; Sinkule, J. A.; Crom, W. R.; Thompson, E. I.; Evans, W. E. J. Chromatogr., 1985, 345, 197.

[51] Tjaden, U. R.; Langenberg, J. P.; Ensing, K.; van Bennekom, W. P.; de Bruijn, E. A.; Van Oosterom, A. T. J. Chromatogr., 1982, 232, 355.

[52] Tjaden, U. R.; de Bruijn, E. A.; van der Hoeven, R. A.; Jol, C.; van der, G. J.; Lingeman, H. J. Chromatogr., 1987, 420, 53.

[53] Dalton, J. T.; Geuns, E. R.; Au, J. L. J. Chromatogr., 1989, 495, 330.

[54] Czejka, M. J.; Jager, W.; Schuller, J. J. Chromatogr., 1989, 497, 336.

[55] Li, W. Y.; Seah, S. K.; Koda, R. T. J. Chromatogr., 1993, 619, 148.

[56] Song, D.; Au, J. L. J. Chromatogr. B Biomed. Appl., 1996, 676, 165.

[57] Paroni, R.; Arcelloni, C.; De, V. E.; Fermo, I.; Mauri, D.; Colombo, R. Clin. Chem., 1997, 43, 615.

[58] Joseph, G.; Biederbick, W.; Woschee, U.; Theisohn, M.; Klaus, W. J. Chromatogr. B Biomed. Sci. Appl., 1997, 698, 261.

[59] Xiong, X.; Lim, B. A.; Lat-Luna, M.; Chew, P.; Tan, D. J. Chromatogr. B Biomed. Sci. Appl., 2001, 755, 65.

[60] Huerva, V.; Mateo, A. J.; Mangues, I.; Jurjo, C. Cornea, 2006, 25, 1220.

[61] Prabhasawat, P.; Tarinvorakup, P.; Tesavibul, N.; Uiprasertkul, M.; Kosrirukvongs, P.; Booranapong, W.; Srivannaboon, S. Cornea, 2005, 24, 443 .

[62] Mahdadi, R.; Kenani, A.; Pommery, N.; Pommery, J.; Henichart, J. P.; Lhermitte, M. Cancer Chemother. Pharmacol., 1991, 28, 22.

[63] Epstein, J. B.; Gorsky, M.; Wong, F. L.; Millner, A. Cancer, 1998, 83,629 .

[64] Lobo, E. D.; Balthasar, J. P. J. Pharm. Sci., 2005, 94, 1957

[65] Cintron, J. R.; Pearl, R. K. Semin. Surg. Oncol., 1996, 12, 267.

[66] Markman, M.; Reichman, B.; Hakes, T.; Curtin, J.; Jones, W.; Lewis, J. L., Jr.; Barakat, R.; Rubin, S.; Mychalczak, B.; Saigo, P. Cancer, 1993, 71, 1565.

[67] Patel, S. R.; Benjamin, R. S. Surg.Oncol., 2000, 9, 67.

[68] Dedrick, R. L.; Myers, C. E.; Bungay, P. M.; DeVita, V. T., Jr. Cancer Treat. Rep., 1978, 62, 1.

[69] Balthasar, J. P.; Fung, H. L. J. Pharm. Sci., 1996, 85, 1035.
[70] Miyagi, Y.; Fujiwara, K.; Kigawa, J.; Itamochi, H.; Nagao, S.; Aotani, E.; Terakawa, N.; Kohno, I. Gynecol. Oncol., 2005, 99, 591.

[71] Steinborner, S.; Henion, J. Anal. Chem., 1999, 71, 2340.

[72] Turci, R.; Micoli, G.; Minoia, C. Rapid Commun. Mass Spectrom., 2000, 14, 685 .

[73] Rule, G.; Chapple, M.; Henion, J. Anal. Chem., 2001, 73, 439.

[74] Barbieri, A.; Sabatini, L.; Indiveri, P.; Bonfiglioli, R.; Lodi, V.; Violante, F. S. Rapid Commun. Mass Spectrom., 2006, 20, 1889.

[75] Steinborner, S.; Henion, J. Anal. Chem., 1999, 71, 2340.

[76] Oman, M.; Lundqvist, S.; Gustavsson, B.; Hafstrom, L. O.; Naredi, P. Cancer Chemother. Pharmacol., 2005, 56, 603 .

[77] Oman, M.; Blind, P. J.; Naredi, P.; Gustavsson, B.; Hafstrom, L. O. Eur. J. Surg. Oncol., 2001, 27, 477.

[78] Gustavsson, B.; Baldesten, A.; Hasselgren, P. O.; Almersjo, O. J. Chromatogr., 1979, 179, 151.

[79] Mahteme, H.; Larsson, B.; Sundin, A.; Khamis, H.; Graf, W. Eur. J. Cancer, 2004, 40, 142.

[80] Lindner, P.; Heath, D. D.; Shalinsky, D. R.; Howell, S. B.; Naredi, P.; Hafstrom, L. Surg. Oncol., 1993, 2, 105.

[81] Verwaal, V. J.; van Ruth S.; de Bree E.; van Sloothen, G. W.; van, T. H.; Boot, H.; Zoetmulder, F. A. J. Clin. Oncol., 2003, 21, 3737.

[82] Sugarbaker, P. H.; Stuart, O. A.; Carmignani, C. P. Cancer Chemother. Pharmacol., 2006, 57, 703.

[83] Ahmed, A. E.; Hsu, T. F. J. Chromatogr., 1981, 222, 453

[84] Hoes, I.; Lemiere, F.; Van, D. W.; Vanhoutte, K.; Esmans, E. L.; Van, B. D.; Berneman, Z.; Deforce, D.; Van den Eeckhout, E. G. J. Chromatogr. B Biomed. Sci. Appl., 1999, 736, 43.

[85] Wu, Z. Y.; Thompson, M. J.; Roberts, M. S.; Addison, R. S.; Cannell, G. R.; Grabs, A. J.; Smithers, B. M. J. Chromatogr. B Biomed. Appl., 1995, 673, 267.

[86] Bosanquet, A. G.; Gilby, E. D. J. Chromatogr., 1982, 232, 345

[87] Adair, C. G.; Burns, D. T.; Crockard, A. D.; Desai, Z. R.; Harriott, M. J. Chromatogr., 1984, 336, 429.

[88] Sweeney, D. J.; Greig, N. H.; Rapoport, S. I. J. Chromatogr., 1985, 339,434

[89] Silvestro, L.; Viano, I.; Baiocchi, C.; Saini, G.; Marmont, F.; Ferro, R. J. Chromatogr., 1991, 563, 443.

[90] Pinguet, F.; Joulia, J. M.; Martel, P.; Grosse, P. Y.; Astre, C.; Bressolle, F. J. Chromatogr. B Biomed. Appl., 1996, 686, 43.

[91] Davies, I. D.; Allanson, J. P.; Causon, R. C. Chromatographia, 2000, 52, S-92-S-97.

[92] Mohamed, F.; Stuart, O. A.; Glehen, O.; Urano, M.; Sugarbaker, P. H. Cancer Chemother. Pharmacol., 2006, 58, 719.

[93] Piccart, M. J.; Abrams, J.; Dodion, P. F.; Crespeigne, N.; Sculier, J. P.; Pector, J. C.; Finet, C.; Nouwijnck, C.; Bondue, H.; Atassi, G. J. Natl. Cancer Inst., 1988, 80, 1118 .

[94] Sugarbaker, P. H.; Stuart, O. A. Cancer Chemother. Pharmacol., 2007, $59,151$.

[95] van Maanen, M. J.; Beijnen, J. H. J. Chromatogr. B Biomed. Sci. Appl., 1999, 732, 73 .

[96] de Jonge, M. E.; van Dam, S. M.; Hillebrand, M. J.; Rosing, H.; Huitema, A. D.; Rodenhuis, S.; Beijnen, J. H. J. Mass Spectrom., 2004, 39, 262.

[97] Tinsley, P. W.; O'Dwyer, P. J.; LaCreta, F. P. J. Chromatogr., 1989, 495, 318.

[98] Zhou, S.; Cook, K. D. J. Am. Soc. Mass Spectrom., 2000, 11, 961

[99] Stokvis, E.; Ouwehand, M.; Nan, L. G.; Kemper, E. M.; van, T. O.; Rosing, H.; Beijnen, J. H. J. Mass Spectrom., 2004, 39, 1506.

[100] Stokvis, E.; Rosing, H.; Crul, M.; Rieser, M. J.; Heck, A. J.; Schellens, J. H.; Beijnen, J. H. J. Mass Spectrom., 2004, 39, 277.

[101] Stokvis, E.; Rosing, H.; Lopez-Lazaro, L.; Rodriguez, I.; Jimeno, J. M.; Supko, J. G.; Schellens, J. H.; Beijnen, J. H. J. Mass Spectrom., 2002, 37, 992.

[102] Vainchtein, L. D.; Thijssen, B.; Stokvis, E.; Rosing, H.; Schellens, J. H.; Beijnen, J. H. Biomed. Chromatogr., 2006, 20, 139.

[103] Feun, L. G.; Blessing, J. A.; Major, F. J.; DiSaia, P. J.; Alvarez, R. D.; Berek, J. S. Gynecol. Oncol., 1998, 71, 410.

[104] Bateman, J. C.; Moulton, B.; Larsen, N. J. AMA. Arch. Intern. Med., 1955, 95, 713 .

[105] Dollinger, M. R. CA Cancer J. Clin., 1972, 22, 138.

[106] Silverberg, I. Oncology, 1970, 24, 26.

[107] Kirmani, S.; McVey, L.; Loo, D.; Howell, S. B. Gynecol. Oncol., 1990, 36, 331 . 
[108] Lewis, C.; Lawson, N.; Rankin, E. M.; Morrison, G.; MacLean, A. B.; Cordiner, J.; Cassidy, J.; Kerr, D. J.; Kaye, S. B. Cancer Chemother. Pharmacol., 1990, 26, 283.

[109] Bell, D. N.; Liu, J. J.; Tingle, M. D.; McKeage, M. J. J. Chromatogr. B Analyt. Technol. Biomed. Life Sci., 2006, 837, 29.

[110] Oestreicher, P. ONS.Connect., 2007, 22, 24

[111] Ozols, R. F.; Bookman, M. A.; du, B. A.; Pfisterer, J.; Reuss, A.; Young, R. C. Gynecol. Oncol., 2006, 103, 1.

[112] Wang, D.; Lippard, S. J. Nat. Rev. Drug Discov., 2005, 4, 307.

[113] Brouwers, E. E. M.; Huitema, A. D. R.; Schellens, J. H. M.; Beijnen, J. H. 2008, Submitted.

[114] Zhao, Z.; Tepperman, K.; Dorsey, J. G.; Elder, R. C. J. Chromatogr., 1993, 615, 83 .

[115] Brouwers, E. E.; Tibben, M. M.; Rosing, H.; Hillebrand, M. J.; Joerger, M.; Schellens, J. H.; Beijnen, J. H. J. Mass Spectrom., 2006, 41, 1186 .

[116] Brouwers, E. E.; Tibben, M. M.; Rosing, H.; Schellens, J. H.; Beijnen, J. H. Mass Spectrom. Rev., 2008, 27(2), 67.

[117] Wang, D.; Lippard, S. J. Nat. Rev. Drug Discov., 2005, 4, 307.

[118] Fujiwara, K.; Markman, M.; Morgan, M.; Coleman, R. L. Gynecol. Oncol., 2005, 97, 10.

[119] Alberts, D. S.; Liu, P. Y.; Hannigan, E. V.; O'Toole, R.; Williams, S. D.; Young, J. A.; Franklin, E. W.; Clarke-Pearson, D. L.; Malviya, V. K.; DuBeshter, B. N. Engl. J. Med., 1996, 335, 1950.

[120] Markman, M.; Bundy, B. N.; Alberts, D. S.; Fowler, J. M.; ClarkPearson, D. L.; Carson, L. F.; Wadler, S.; Sickel, J. J. Clin. Oncol., 2001, 19, 1001 .

[121] Royer, B.; Guardiola, E.; Polycarpe, E.; Hoizey, G.; Delroeux, D.; Combe, M.; Chaigneau, L.; Samain, E.; Chauffert, B.; Heyd, B.; Kantelip, J. P.; Pivot, X. Anticancer Drugs, 2005, 16, 1009.

[122] Guo, P.; Li, S.; Gallo, J. M. J. Chromatogr. B Analyt. Technol. Biomed. Life Sci., 2003, 783, 43.

[123] Wang, D.; Lippard, S. J. Nat. Rev. Drug Discov., 2005, 4, 307.

[124] Elias, D.; Goere, D.; Blot, F.; Billard, V.; Pocard, M.; KohnehShahri, N.; Raynard, B. Ann. Surg. Oncol., 2007, 14, 1818.

[125] Gesson-Paute, A.; Ferron, G.; Thomas, F.; de Lara, E. C.; Chatelut, E.; Querleu, D. Ann. Surg. Oncol., 2007.

[126] Rowinsky, E. K. Semin. Oncol., 1997, 24, S19.

[127] Rowinsky, E. K.; Wright, M.; Monsarrat, B.; Lesser, G. J.; Donehower, R. C. Cancer Surv., 1993, 17, 283.

[128] Monsarrat, B.; Chatelut, E.; Royer, I.; Alvinerie, P.; Dubois, J.; Dezeuse, A.; Roche, H.; Cros, S.; Wright, M.; Canal, P. Drug Metab. Dispos., 1998, 26, 229.

[129] Arora, S.; Yang, J. M.; Utsumi, R.; Okamoto, T.; Kitayama, T.; Hait, W. N. Mol. Pharmacol., 2004, 66, 460

[130] Monsarrat, B.; Mariel, E.; Cros, S.; Gares, M.; Guenard, D.; Gueritte-Voegelein, F.; Wright, M. Drug Metab. Dispos., 1990, 18, 895.

[131] Monsarrat, B.; Alvinerie, P.; Wright, M.; Dubois, J.; GueritteVoegelein, F.; Guenard, D.; Donehower, R. C.; Rowinsky, E. K. J. Natl. Cancer Inst. Monogr., 1993, 39.

[132] Cresteil, T.; Monsarrat, B.; Dubois, J.; Sonnier, M.; Alvinerie, P.; Gueritte, F. Drug Metab. Dispos., 2002, 30, 438.

[133] Sonnichsen, D. S.; Liu, Q.; Schuetz, E. G.; Schuetz, J. D.; Pappo, A.; Relling, M. V. J. Pharmacol. Exp. Ther., 1995, 275, 566.

[134] Huizing, M. T.; Rosing, H.; Koopman, F.; Keung, A. C.; Pinedo, H. M.; Beijnen, J. H. J. Chromatogr. B Biomed. Appl., 1995, 664, 373.

[135] Rosing, H.; Lustig, V.; Koopman, F. P.; ten Bokkel Huinink, W. W.; Beijnen, J. H. J. Chromatogr. B Biomed. Sci. Appl., 1997, 696, 89.

[136] Sottani, C.; Minoia, C.; D'Incalci, M.; Paganini, M.; Zucchetti, M. Rapid Commun. Mass Spectrom., 1998, 12, 251.

[137] Alexander, M. S.; Kiser, M. M.; Culley, T.; Kern, J. R.; Dolan, J. W.; McChesney, J. D.; Zygmunt, J.; Bannister, S. J. J. Chromatogr. B Analyt. Technol. Biomed. Life Sci., 2003, 785, 253.

[138] Parise, R. A.; Ramanathan, R. K.; Zamboni, W. C.; Egorin, M. J. J. Chromatogr. B Analyt. Technol. Biomed. Life Sci., 2003, 783, 231.

[139] Schellen, A.; Ooms, B.; van, G. M.; Halmingh, O.; van, d., V; van de, L. D.; Verheij, E. Rapid Commun. Mass Spectrom., 2000, 14, 230 .

[140] Tong, X.; Zhou, J.; Tan, Y. J. Chromatogr. Sci., 2006, 44, 266.

[141] Gardner, E. R.; Liau, C. T.; Chu, Z. E.; Figg, W. D.; Sparreboom, A. Rapid Commun. Mass Spectrom., 2006, 20, 2170.

[142] Green, H.; Vretenbrant, K.; Norlander, B.; Peterson, C. Rapid Commun. Mass Spectrom., 2006, 20, 2183.
[143] Yonemoto, H.; Ogino, S.; Nakashima, M. N.; Wada, M.; Nakashima, K. Biomed. Chromatogr., 2007, 21, 310.

[144] Zufia, L. L.; Aldaz, P. A.; ramendia Beitia, J. M.; Arrobas, V. J.; Giraldez, D. J. Ther. Drug Monit., 2006, 28, 199.

[145] Armstrong, D. K.; Bundy, B.; Wenzel, L.; Huang, H. Q.; Baergen, R.; Lele, S.; Copeland, L. J.; Walker, J. L.; Burger, R. A. N. Engl. J. Med., 2006, 354, 34 .

[146] Armstrong, D. K.; Fleming, G. F.; Markman, M.; Bailey, H. H. Gynecol. Oncol., 2006, 103, 391.

[147] Tsai, M.; Lu, Z.; Wang, J.; Yeh, T. K.; Wientjes, M. G.; Au, J. L. Pharm. Res., 2007, 24, 1691.

[148] Markman, M.; Rowinsky, E.; Hakes, T.; Reichman, B.; Jones, W.; Lewis, J. L., Jr.; Rubin, S.; Curtin, J.; Barakat, R.; Phillips, M. J Clin. Oncol., 1992, 10, 1485.

[149] Francis, P.; Rowinsky, E.; Schneider, J.; Hakes, T.; Hoskins, W.; Markman, M. J. Clin. Oncol., 1995, 13, 2961.

[150] Yokogawa, K.; Jin, M.; Furui, N.; Yamazaki, M.; Yoshihara, H.; Nomura, M.; Furukawa, H.; Ishizaki, J.; Fushida, S.; Miwa, K.; Miyamoto, K. J. Pharm. Pharmacol., 2004, 56, 629

[151] Markman, M.; Brady, M. F.; Spirtos, N. M.; Hanjani, P.; Rubin, S. C. J. Clin. Oncol., 1998, 16, 2620-24.

[152] Ho, E. A.; Soo, P. L.; Allen, C.; Piquette-Miller, M. J. Control Release, 2007, 117, 20.

[153] Mohamed, F.; Marchettini, P.; Stuart, O. A.; Sugarbaker, P. H. Cancer Chemother. Pharmacol., 2003, 52, 405.

[154] de Bree E.; Rosing, H.; Beijnen, J. H.; Romanos, J.; Michalakis, J.; Georgoulias, V.; Tsiftsis, D. D. Anticancer Drugs, 2003, 14, 103.

[155] de Bree E.; Theodoropoulos, P. A.; Rosing, H.; Michalakis, J.; Romanos, J.; Beijnen, J. H.; Tsiftsis, D. D. Cancer Treat. Rev., 2006, 32, 471 .

[156] Marchettini, P.; Stuart, O. A.; Mohamed, F.; Yoo, D.; Sugarbaker, P. H. Cancer Chemother. Pharmacol., 2002, 49, 499.

[157] Mohamed, F.; Stuart, O. A.; Sugarbaker, P. H. J. Surg. Res., 2003, 113,114

[158] Wang, L. Z.; Goh, B. C.; Grigg, M. E.; Lee, S. C.; Khoo, Y. M.; Lee, H. S. Rapid Commun. Mass Spectrom., 2003, 17, 1548.

[159] Vries, N. A.; Ouwehand, M.; Buckle, T.; Beijnen, J. H.; van, T. O. Biomed. Chromatogr., 2007, 21, 1191.

[160] Beijnen, J. H.; Smith, B. R.; Keijer, W. J.; van, G. R.; ten Bokkel Huinink, W. W.; Vlasveld, L. T.; Rodenhuis, S.; Underberg, W. J. J. Pharm. Biomed. Anal., 1990, 8, 789.

[161] Rosing, H.; van Zomeren, D. M.; Doyle, E.; ten Bokkel, W. W.; Schellens, J. H.; Bult, A.; Beijnen, J. H. J. Chromatogr. B Biomed. Sci. Appl., 1999, 727, 191.

[162] Vali, A. M.; Shafaghi, B.; Dadashzadeh, S. J. Chromatogr. B Analyt. Technol. Biomed. Life Sci., 2005, 818, 205.

[163] Warner, D. L.; Burke, T. G. J. Chromatogr. B Biomed. Sci. Appl., 1997, 691, 161.

[164] Rosing, H.; Doyle, E.; Davies, B. E.; Beijnen, J. H. J. Chromatogr B Biomed. Appl., 1995, 668, 107.

[165] Bai, F.; Kirstein, M. N.; Hanna, S. K.; Iacono, L. C.; Johnston, B.; Stewart, C. F. J. Chromatogr. B Analyt. Technol. Biomed. Life Sci., 2003, 784, 225.

[166] Plaxe, S. C.; Christen, R. D.; O'Quigley, J.; Braly, P. S.; Freddo, J. L.; McClay, E.; Heath, D.; Howell, S. B. Invest. New Drugs, 1998 $16,147$.

[167] Bos, A. M.; De Vos, F. Y.; de Vries, E. G.; Beijnen, J. H.; Rosing, H.; Mourits, M. J.; van der Zee, A. G.; Gietema, J. A.; Willemse, P. H. Eur. J. Cancer, 2005, 41, 539.

[168] Hofstra, L. S.; Bos, A. M.; de Vries, E. G.; van der Zee, A. G.; Beijnen, J. H.; Rosing, H.; Mulder, N. H.; Aalders, J. G.; Willemse, P. H. Br. J. Cancer, 2001, 85, 1627.

[169] Finkelstein, Y.; Zevin, S.; Heyd, J.; Bentur, Y.; Zigelman, Y.; Hersch, M. Neurotoxicology 2004, 25, 407.

[170] Arkenau, H. T.; Chong, G.; Cunningham, D.; Watkins, D.; Agarwal, R.; Sirohi, B.; Trumper, M.; Norman, A.; Wotherspoon, A. Horwich, A. Ann. Oncol., 2007, 18, 541

[171] Alexopoulou, A.; Dourakis, S. P.; Georgousi, K. K.; Archimandritis, A. J. Am. J. Hematol., 2005, 78, 159.

[172] Yoshida, S.; Morii, K. Surg. Neurol., 2005, 63, 52.

[173] Bode, U.; Magrath, I. T.; Bleyer, W. A.; Poplack, D. G.; Glaubiger, D. L. Cancer Res., 1980, 40, 2184

[174] Thyss, A.; Suciu, S.; Bertrand, Y.; Mazingue, F.; Robert, A.; Vilmer, E.; Mechinaud, F.; Benoit, Y.; Brock, P.; Ferster, A.; Lutz, P.; Boutard, P.; Marguerite, G.; Plouvier, E.; Michel, G.; Plantaz, D.; 
Munzer, M.; Rialland, X.; Chantraine, J. M.; Norton, L.; Solbu, G.; Philippe, N.; Otten, J. J. Clin. Oncol., 1997, 15, 1824.

[175] Bostrom, B. C.; Erdmann, G. R.; Kamen, B. A. J. Pediatr. Hematol. Oncol., 2003, 25, 114 .

[176] Bleyer, W. A.; Dedrick, R. L. Cancer Treat. Rep., 1977, 61, 703.

[177] Ettinger, L. J.; Chervinsky, D. S.; Freeman, A. I.; Creaven, P. J. Cancer, 1982, 50, 1676.

[178] Chabner, B. A.; Young, R. C. J. Clin. Invest., 1973, 52, 1804.

[179] Fahmy, O. T.; Korany, M. A.; Maher, H. M. J. Pharm. Biomed. Anal., 2004, 34, 1099.

[180] Hsieh, Y.; Duncan, C. J.; Brisson, J. M. Rapid Commun. Mass Spectrom., 2007, 21, 629.

[181] Hsieh, Y.; Duncan, C. J. Rapid Commun. Mass Spectrom., 2007, $21,573$.

[182] Hsieh, Y.; Li, F.; Duncan, C. J. Anal. Chem., 2007, 79, 3856.

[183] Jabbour, E.; O'Brien, S.; Kantarjian, H.; Garcia-Manero, G.; Ferrajoli, A.; Ravandi, F.; Cabanillas, M.; Thomas, D. A. Blood, 2007, 109, 3214.

[184] Benesch, M.; Sovinz, P.; Krammer, B.; Lackner, H.; Mann, G.; Schwinger, W.; Gadner, H.; Urban, C. J. Pediatr. Hematol. Oncol., 2007, 29, 222.

[185] Bomgaars, L.; Geyer, J. R.; Franklin, J.; Dahl, G.; Park, J.; Winick, N. J.; Klenke, R.; Berg, S. L.; Blaney, S. M. J. Clin. Oncol. 2004, 22, 3916.

[186] D'Angio, G. J. J. Pediatr. Hematol. Oncol., 2005, 27, 349.

[187] Pound, C. M.; Keene, D. L.; Udjus, K.; Humphreys, P.; Johnston, D. L. J. Pediatr. Hematol. Oncol., 2007, 29, 183.

[188] Chamberlain, M. C.; Glantz, M. J. Blood, 2007, 110, 1698.

[189] Fisher, P. G.; Kadan-Lottick, N. S.; Korones, D. N. J. Pediatr. Hematol. Oncol., 2002, 24, 274.

[190] Witham, T. F.; Fukui, M. B.; Meltzer, C. C.; Burns, R.; Kondziolka, D.; Bozik, M. E. Cancer, 1999, 86, 1347.

[191] dos Reis, E. O.; Vianna-Jorge, R.; Suarez-Kurtz, G.; Lima, E. L.; Azevedo, D. A. Rapid Commun. Mass Spectrom., 2005, 19, 1666.

[192] Gururangan, S.; Petros, W. P.; Poussaint, T. Y.; Hancock, M. L.; Phillips, P. C.; Friedman, H. S.; Bomgaars, L.; Blaney, S. M.; Kun, L. E.; Boyett, J. M. Clin. Cancer Res., 2006, 12, 1540.

[193] Quernin, M. H.; Duval, M.; Litalien, C.; Vilmer, E.; Aigrain, E. J. J. Chromatogr. B Biomed. Sci. Appl., 2001, 763, 61.

[194] Quernin, M. H.; Poonkuzhali, B.; Medard, Y.; Dennison, D.; Srivastava, A.; Krishnamoorthy, R.; Chandy, M.; Jacqz-Aigrain, E. J. Chromatogr. B Biomed. Sci. Appl., 1999, 721, 147.

[195] Funakoshi, K.; Yamashita, K.; Chao, W.; Yamaguchi, M.; Yashiki, T. J. Chromatogr. B Biomed. Appl., 1994, 660, 200.

[196] Peris, J. E.; Latorre, J. A.; Castel, V.; Verdeguer, A.; Esteve, S.; Torres-Molina, F. J. Chromatogr. B Biomed. Sci. Appl., 1999, 730, 33.

[197] Rauh, M.; Stachel, D.; Kuhlen, M.; Groschl, M.; Holter, W.; Rascher, W. Clin. Pharmacokinet., 2006, 45, 305.

[198] Blaney, S. M.; Balis, F. M.; Berg, S.; Arndt, C. A.; Heideman, R.; Geyer, J. R.; Packer, R.; Adamson, P. C.; Jaeckle, K.; Klenke, R.; Aikin, A.; Murphy, R.; McCully, C.; Poplack, D. G. J. Clin. Oncol., 2005, 23, 1555 .

[199] Sadagopan, N.; Cohen, L.; Roberts, B.; Collard, W.; Omer, C. J. Chromatogr. B Biomed. Sci. Appl., 2001, 759, 277.

[200] Baumann, F.; Lorenz, C.; Jaehde, U.; Preiss, R. J. Chromatogr. B Biomed. Sci. Appl., 1999, 729, 297.

[201] Slattery, J. T.; Kalhorn, T. F.; McDonald, G. B.; Lambert, K.; Buckner, C. D.; Bensinger, W. I.; Anasetti, C.; Appelbaum, F. R. J. Clin. Oncol., 1996, 14, 1484.

[202] Hong, P. S.; Chan, K. K. J. Chromatogr., 1989, 495, 131.

[203] Wright, J. E.; Tretyakov, O.; Ayash, L. J.; Elias, A.; Rosowsky, A.; Frei, E., III Anal. Biochem., 1995, 224, 154.

[204] Ekhart, C.; Gebretensae, A.; Rosing, H.; Rodenhuis, S.; Beijnen, J. H.; Huitema, A. D. J. Chromatogr. B Analyt. Technol. Biomed. Life Sci., 2007, 854, 345.

[205] Blaney, S. M.; Boyett, J.; Friedman, H.; Gajjar, A.; Geyer, R.; Horowtiz, M.; Hunt, D.; Kieran, M.; Kun, L.; Packer, R.; Phillips, P.; Pollack, I. F.; Prados, M.; Heideman, R. J. Clin. Oncol., 2005, 23,525 .

[206] Blaney, S. M.; Balis, F. M.; Berg, S.; Arndt, C. A.; Heideman, R.; Geyer, J. R.; Packer, R.; Adamson, P. C.; Jaeckle, K.; Klenke, R.; Aikin, A.; Murphy, R.; McCully, C.; Poplack, D. G. J. Clin. Oncol., 2005, 23, 1555 .

[207] Alacron, J. Anal. Chem., 1968, 30, 1704.
[208] Gammon, D. C.; Bhatt, M. S.; Tran, L.; Van, H. A.; Benvenuti, M.; Glantz, M. J. Am. J. Health Syst. Pharm., 2006, 63, 2083.

[209] Blaney, S. M.; Heideman, R.; Berg, S.; Adamson, P.; Gillespie, A.; Geyer, J. R.; Packer, R.; Matthay, K.; Jaeckle, K.; Cole, D.; Kuttesch, N.; Poplack, D. G.; Balis, F. M. J. Clin. Oncol., 2003, 21, 143.

[210] Blaney, S. M.; Heideman, R.; Berg, S.; Adamson, P.; Gillespie, A.; Geyer, J. R.; Packer, R.; Matthay, K.; Jaeckle, K.; Cole, D.; Kuttesch, N.; Poplack, D. G.; Balis, F. M. J. Clin. Oncol., 2003, 21, 143.

[211] Blaney, S. M.; Cole, D. E.; Godwin, K.; Sung, C.; Poplack, D. G.; Balis, F. M. Cancer Chemother. Pharmacol., 1995, 36, 121.

[212] Badalament, R. A.; Farah, R. N. Semin. Surg. Oncol., 1997, 13, 335.

[213] Lamm, D. L.; McGee, W. R.; Hale, K. Urol. Nurs., 2005, 25, 323.

[214] Nilsson, S.; Ragnhammar, P.; Glimelius, B.; Nygren, P. Acta Oncol., 2001, 40, 371 .

[215] Saxena, S.; Agrawal, U.; Agarwal, A.; Murthy, N. S.; Mohanty, N. K. BJU. Int., 2006, 98, 1012.

[216] Clarke, N. S.; Basu, S.; Prescott, S.; Puri, R. BJU. Int., 2006, 97, 716.

[217] Gardmark, T.; Jahnson, S.; Wahlquist, R.; Wijkstrom, H.; Malmstrom, P. U. BJU Int., 2007, 99, 817.

[218] Kaasinen, E.; Wijkstrom, H.; Malmstrom, P. U.; Hellsten, S.; Duchek, M.; Mestad, O.; Rintala, E. Eur. Urol., 2003, 43, 637.

[219] Mostafid, A. H.; Rajkumar, R. G.; Stewart, A. B.; Singh, R. BJU Int., 2006, 97, 509.

[220] Kuroda, M.; Niijima, T.; Kotake, T.; Akaza, H.; Hinotsu, S. Eur. Urol., 2004, 45, 600 .

[221] McDonald, C. E. Urol. Nurs., 2007, 27, 210.

[222] Mitsumori, K.; Tsuchiya, N.; Habuchi, T.; Li, Z.; Akao, T.; Ohyama, C.; Sato, K.; Kato, T. BJU Int., 2004, 94, 317.

[223] Puri, R.; Palit, V.; Loadman, P. M.; Flannigan, M.; Shah, T.; Choudry, G. A.; Basu, S.; Double, J. A.; Lenaz, G.; Chawla, S.; Beer, M.; Van, K. C.; de, B. R.; Beijnen, J. H.; Twelves, C. J.; Phillips, R. M. J. Urol., 2006, 176, 1344.

[224] van der Heijden, A. G.; Moonen, P. M.; Cornel, E. B.; Vergunst, H.; de Reijke, T. M.; van, B. E.; Barten, E. J.; Puri, R.; van Kalken, C. K.; Witjes, J. A. J. Urol., 2006, 176, 1349.

[225] Masters, J. R.; McDermott, B. J.; Harland, S.; Bibby, M. C.; Loadman, P. M. Cancer Chemother. Pharmacol., 1996, 38, 59.

[226] Ord, J. J.; Streeter, E.; Jones, A.; Le, M. K.; Cranston, D.; Crew, J.; Joel, S. P.; Rogers, M. A.; Banks, R. E.; Roberts, I. S.; Harris, A. L. Br. J. Cancer, 2005, 92, 2140 .

[227] Uchio, E. M.; Linehan, W. M.; Figg, W. D.; Walther, M. M. J. Urol., 2003, 169, 357.

[228] Walther, M. M.; Figg, W. D.; Linehan, W. M. World J. Urol., 1996, 14 Suppl 1, S8.

[229] Graham, S. D., Jr.; Napalkov, P.; Oladele, A.; Keane, T. E.; Petros, J. A.; Clarke, H. S.; Kassabian, V. S.; Dillehay, D. L. Urology, 1995, 45, 59

[230] Laufer, M.; Ramalingam, S.; Schoenberg, M. P.; Haisfield-Wolf, M. E.; Zuhowski, E. G.; Trueheart, I. N.; Eisenberger, M. A.; Nativ, O.; Egorin, M. J. J. Clin. Oncol., 2003, 21, 697.

[231] Dalton, J. T.; Wientjes, M. G.; Badalament, R. A.; Drago, J. R.; $\mathrm{Au}$, J. L. Cancer Res., 1991, 51, 5144.

[232] Wientjes, M. G.; Badalament, R. A.; Wang, R. C.; Hassan, F.; Au, J. L. Cancer Res., 1993, 53, 3314.

[233] Crooke, S. T.; Henderson, M.; Samson, M.; Baker, L. H. Cancer Treat. Rep., 1976, 60, 1633.

[234] Vainchtein, L. D.; Rosing, H.; Mirejovsky, D.; Huynh, V.; Lenaz, L.; Hillebrand, M. J.; Schellens, J. H.; Beijnen, J. H. J. Mass Spectrom., 2006, 41, 1268.

[235] Vainchtein, L. D.; Rosing, H.; Mirejovsky, D.; Lenaz, L.; Schellens, J. H.; Beijnen, J. H. J. Pharm. Biomed. Anal., 2007, 43, 285.

[236] van der Schoot, S. C.; Vainchtein, L. D.; Beijnen, J. H.; Gore, A.; Mirejovsky, D.; Lenaz, L.; Nuijen, B. Int. J. Pharm., 2007, 329, 135.

[237] Vainchtein, L. D.; Rosing, H.; Mirejovsky, D.; Huynh, V.; Lenaz, G.; Schellens, J. H.; Beijnen, J. H. Rapid Commun. Mass. Spectrom, 2008, 22(4), 462.

[238] McDermott, B. J.; Double, J. A.; Bibby, M. C.; Wilman, D. E.; Loadman, P. M.; Turner, R. L. J. Chromatogr., 1985, 338, 335.

[239] Chin, D. L.; Lum, B. L.; Sikic, B. I. J. Chromatogr. B Analyt. Technol. Biomed. Life Sci., 2002, 779, 259.

[240] Pierce, R. N.; Jatlow, P. I. J. Chromatogr., 1979, 164, 471. 
[241] Kotake, A. N.; Vogelzang, N. J.; Larson, R. A.; Choporis, N. J. Chromatogr., 1985, 337, 194.

[242] Dobbs, N. A.; James, C. A. J. Chromatogr., 1987, 420, 184.

[243] Camaggi, C. M.; Comparsi, R.; Strocchi, E.; Testoni, F.; Pannuti, F. Cancer Chemother. Pharmacol., 1988, 21, 216.

[244] Beijnen, J. H.; Meenhorst, P. L.; van, G. R.; Fromme, M.; Rosing, H.; Underberg, W. J. J. Pharm. Biomed. Anal., 1991, 9, 995.

[245] de Bruijn P.; Verweij, J.; Loos, W. J.; Kolker, H. J.; Planting, A. S.; Nooter, K.; Stoter, G.; Sparreboom, A. Anal. Biochem., 1999, 266, 216.

[246] Mou, C.; Ganju, N.; Sridhar, K. S.; Krishan, A. J. Chromatogr. B Biomed. Sci. Appl., 1997, 703, 217.

[247] Ricciarello, R.; Pichini, S.; Pacifici, R.; Altieri, I.; Pellegrini, M.; Fattorossi, A.; Zuccaro, P. J. Chromatogr. B Biomed. Sci. Appl., 1998, 707, 219.

[248] Zhao, P.; Dash, A. K. J. Pharm. Biomed. Anal., 1999, 20, 543.

[249] Lachatre, F.; Marquet, P.; Ragot, S.; Gaulier, J. M.; Cardot, P.; Dupuy, J. L. J. Chromatogr. B Biomed. Sci. Appl., 2000, 738, 281.

[250] Schwartz, M. S.; Matuszewski, B. K. J. Chromatogr. B Analyt. Technol. Biomed. Life Sci., 2002, 780, 171.

[251] DiFrancesco, R.; Griggs, J. J.; Donnelly, J.; DiCenzo, R. J. Chromatogr. B Analyt. Technol. Biomed. Life Sci., 2007, 852, 545.

[252] Nagaraj, S.; Karnes, H. T. Biomed. Chromatogr., 2000, 14, 234.

[253] Reinhoud, N. J.; Tjaden, U. R.; Irth, H.; van der, G. J. J. Chromatogr., 1992, 574, 327.

[254] Perez-Ruiz, T.; Martinez-Lozano, C.; Sanz, A.; Bravo, E. Electrophoresis, 2001, 22, 134.

[255] Eder, A. R.; Chen, J. S.; Arriaga, E. A. Electrophoresis, 2006, 27, 3263.

[256] Eder, A. R.; Arriaga, E. A. J. Chromatogr. B Analyt. Technol. Biomed. Life Sci., 2005, 829, 115.

[257] Anderson, A. B.; Gergen, J.; Arriaga, E. A. J. Chromatogr. B Analyt. Technol. Biomed. Life Sci., 2002, 769, 97.

[258] Anderson, A. B.; Ciriacks, C. M.; Fuller, K. M.; Arriaga, E. A. Anal. Chem., 2003, 75, 8.

[259] Wientjes, M. G.; Badalament, R. A.; Au, J. L. Cancer Chemother. Pharmacol., 1996, 37, 539.

[260] Badea, I.; Lazar, L.; Moja, D.; Nicolescu, D.; Tudose, A. J. Pharm. Biomed. Anal., 2005, 39, 305.

[261] Dodde, W. I.; Maring, J. G.; Hendriks, G.; Wachters, F. M.; Groen, H. J.; de Vries, E. G.; Uges, D. R. Ther. Drug Monit., 2003, 25, 433.

[262] Fogli, S.; Danesi, R.; Innocenti, F.; Di, P. A.; Bocci, G.; Barbara, C.; Del, T. M. Ther. Drug Monit., 1999, 21, 367.

[263] Tsushima, T.; Miyaji, Y.; Noda, M.; Nasu, Y.; Kumon, H.; Ohmori, H. Urol. Int., 1998, 60, 161.

[264] Marangon, E.; Sala, F.; Caffo, O.; Galligioni, E.; D'Incalci, M.; Zucchetti, M. J. Mass Spectrom., 2007.

[265] Lanz, C.; Fruh, M.; Thormann, W.; Cerny, T.; Lauterburg, B. H. J. Sep. Sci., 2007, 30, 1811.
[266] Sottani, C.; Turci, R.; Schierl, R.; Gaggeri, R.; Barbieri, A.; Violante, F. S.; Minoia, C. Rapid Commun. Mass Spectrom., 2007, $21,1289$.

[267] Honeywell, R.; Laan, A. C.; van Groeningen, C. J.; Strocchi, E.; Ruiter, R.; Giaccone, G.; Peters, G. J. J. Chromatogr. B Analyt. Technol. Biomed. Life Sci., 2007, 847, 142.

[268] Kirstein, M. N.; Hassan, I.; Guire, D. E.; Weller, D. R.; Dagit, J. W.; Fisher, J. E.; Remmel, R. P. J. Chromatogr. B Analyt. Technol. Biomed. Life Sci., 2006, 835, 136.

[269] Yilmaz, B.; Kadioglu, Y. Y.; Aksoy, Y. J. Chromatogr. B Analyt. Technol. Biomed. Life Sci., 2003, 791, 103.

[270] Keith, B.; Xu, Y.; Grem, J. L. J. Chromatogr. B Analyt. Technol. Biomed. Life Sci., 2003, 785, 65.

[271] Lin, N. M.; Zeng, S.; Ma, S. L.; Fan, Y.; Zhong, H. J.; Fang, L. Acta Pharmacol. Sin., 2004, 25, 1584.

[272] Vainchtein, L. D.; Rosing, H.; Thijssen, B.; Schellens, J. H.; Beijnen, J. H. Rapid Commun. Mass Spectrom., 2007, 21, 2312.

[273] Witjes, J. A.; van der Heijden, A. G.; Vriesema, J. L.; Peters, G. J.; Laan, A.; Schalken, J. A. Eur. Urol., 2004, 45, 182.

[274] Hendricksen, K.; Witjes, J. A. Curr. Opin.Urol., 2006, 16, 361.

[275] Remaud, G.; Boisdron-Celle, M.; Morel, A.; Gamelin, A. J. Chromatogr. B Analyt. Technol. Biomed. Life Sci., 2005, 824, 153.

[276] Guichard, S. M.; Mayer, I.; Jodrell, D. I. J. Chromatogr. B Analyt. Technol. Biomed. Life Sci., 2005, 826, 232.

[277] Zufia, L.; Aldaz, A.; Giraldez, J. J. Chromatogr. B Analyt. Technol. Biomed. Life Sci., 2004, 809, 51.

[278] Safgren, S. L.; Reid, J. M.; Rios, R.; Ames, M. M. J. Chromatogr. B Biomed. Sci. Appl., 2001, 754, 91.

[279] Lemire, S. W.; Ashley, D. L.; Calafat, A. M. J. Anal. Toxicol., 2003, 27,1 .

[280] Ranalder, U. B.; Lausecker, B. B.; Huselton, C. J. Chromatogr., 1993, 617, 129.

[281] Wyss, R.; Bucheli, F. J. Chromatogr. B Biomed. Sci. Appl., 1997, $700,31$.

[282] Gundersen, T. E.; Lundanes, E.; Blomhoff, R. J. Chromatogr. B Biomed. Sci. Appl., 1997, 691, 43.

[283] Lefebvre, P.; Agadir, A.; Cornic, M.; Gourmel, B.; Hue, B.; Dreux, C.; Degos, L.; Chomienne, C. J. Chromatogr. B Biomed. Appl., 1995, 666, 55.

[284] Berthou, F.; Dreano, Y. J. Chromatogr., 1993, 616, 117.

[285] Rustenbeck, I.; Lenzen, S. J. Chromatogr., 1990, 525, 85.

[286] Wu, Z. Y.; Thompson, M. J.; Roberts, M. S.; Addison, R. S.; Cannell, G. R.; Grabs, A. J.; Smithers, B. M. J. Chromatogr. B Biomed. Appl., 1995, 673, 267.

[287] Hsieh, Y.; Duncan, C. J. Rapid Commun. Mass Spectrom., 2007, 21,573 .

[288] Vainchtein, L. D.; Rosing, H.; Ouwehand, M.; Mirejovsky, D.; Huynh, V.; Lenaz, G.; Schellens, J. H.; Beijnen, J. H. 2008, Submitted. 